\title{
Concreto com Agregado Graúdo Proveniente da Reciclagem de Resíduos de Construção e Demolição. Um Novo Material para Fabricação de Painéis Leves de Vedação.
}

Dissertação apresentada à Escola de Engenharia de São Carlos, da Universidade de São Paulo, como parte dos requisitos para obtenção do título de Mestre em Engenharia de Estruturas.

Orientador: Prof. Dr. Eloy Ferraz Machado Jr.

São Carlos

1998 


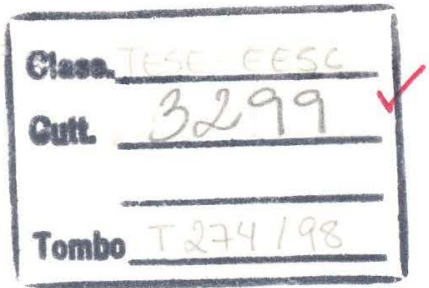

1003328

Ficha catalográfica preparada pela Seção de Tratamento da Inform ação do Serviço de Biblioteca - EESC-USP

Latterza, Luciano de Mello
Concreto com agregado graúdo proveniente da
reciclagem de resíduos de construção e demolição:
um novo material para fabricação de painéis leves
de vedação / Luciano de Mello Latterza. -- São
Carlos, 1998.
Dissertação (Mestrado) -- Escola de Engenharia
de São Carlos-Universidade de São Paulo, 1998.
Area: Engenharia de Estruturas.
Orientador: Prof. Dr. Eloy Ferraz Machado Jr.
1. Concreto. 2. Reciclagem. 3. Resíduos de
demolição. I. Título.


Candidato: Engenheiro LUCIANO DE MELLO LATTERZA

Dissertação defendida e aprovada em 18.08 .1998 pela Comissão Julgadora:

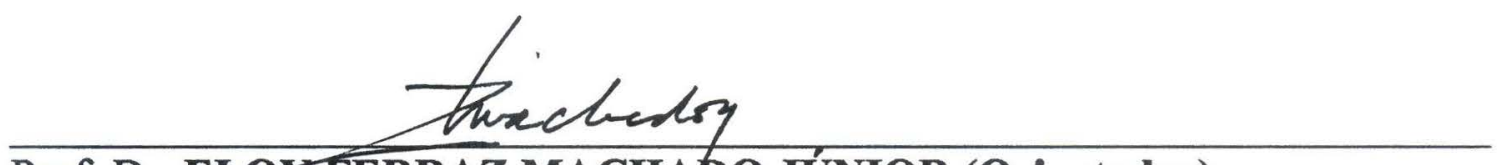

Prof. Dr. ELOF FERRAZ MACHADO JÚNIOR (Orientador)

(Escola de Engenharia de São Carlos - Universidade de São Paulo)

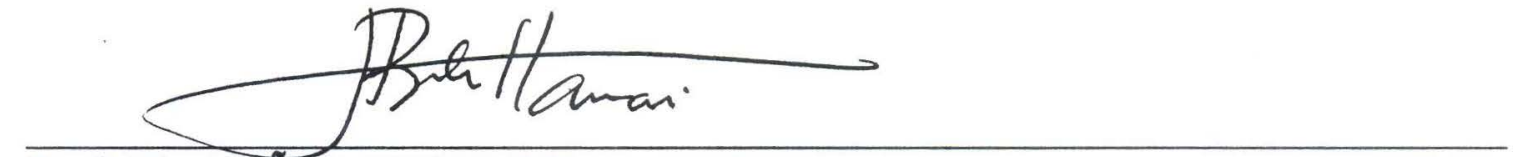

Prof. Tit. JOAO BENTO DE HANAI

(Escola de Engenharia de São Carlos - Universidade de São Paulo)

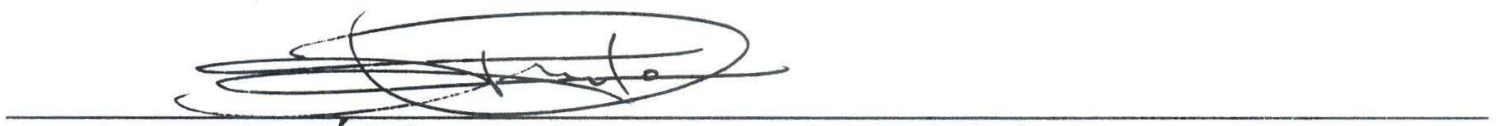

Arquiteto TARCÍSIO DE PAULA PINTO (Especialista)

(Informações e Técnicas em Construção Civil - I \& T)
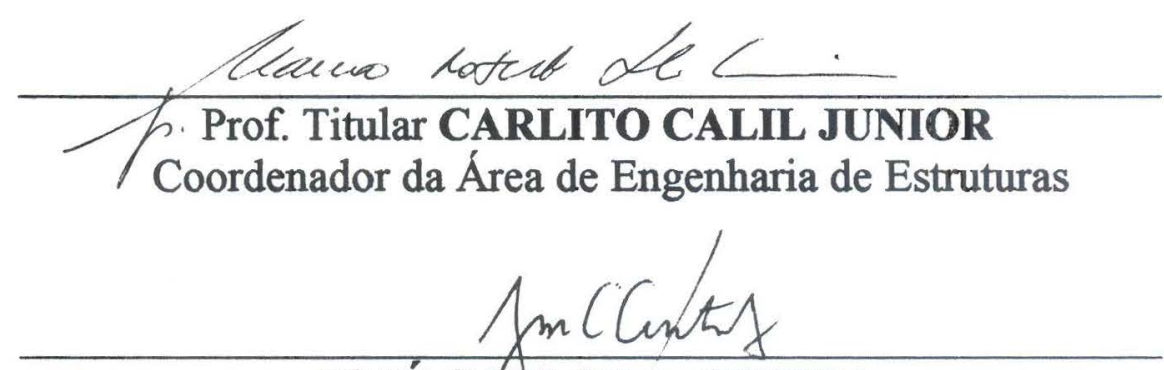

JOSÉ CARLOS A. CINTRA

Presidente da Comissão de Pós-Graduação da EESC 
Aos meus pais, que proporcionaram todas as condições para que eu alcançasse esta meta. 
"Tudo tem o seu tempo determinado, e há tempo para todo propósito debaixo do céu. “

Eclesiastes 3:1 


\section{AGRADECIMENTOS}

Ao Professor Eloy F. Machado Jr., pela orientação, incentivo e grande paciência durante toda a execução deste trabalho. Muito obrigado.

Ao Professor Tarcísio de Paula Pinto, pelo apoio e incentivo no desenvolvimento de um assunto tão complexo.

Aos funcionários do Laboratório de Estruturas, pela dedicação aos serviços prestados com relação aos ensaios.

Aos alunos de graduação Cristiane Lopes Mendes e Jônatas José de Oliveira Lopes, pela colaboração durante os ensaios.

Ao Departamento de Estradas de Rodagem do Município de Ribeirão Preto - D.E.R.M.U.R.P., pelo fornecimento dos dados e materiais necessários para a pesquisa.

Ao amigo Alexandre de Araújo Bertini, pela amizade e total companheirismo em todos os momentos.

À engenheira Dálim, pela enorme ajuda e amizade que me foram dodas.

A Maria Nadir Minatel, pela dedicação sempre prestativa no atendimento como pessoa e bibliotecária.

Ao CNPq, pela bolsa de estudos no período inicial.

Aos Professores e Funcionários do Departamento de Estruturas da EESC - Escola de Engenharia de São Carlos, responsáveis pela complementação de nossa formação.

A todos que direta ou indiretamente contribuíram para a realização deste trabalho.

Aos Homens, os meus mais sinceros agradecimentos; a Deus, toda honra, toda glória, todo louvor,

Amém. 


\section{SUMÁRIO}

RESUMO $\mathbf{v}$

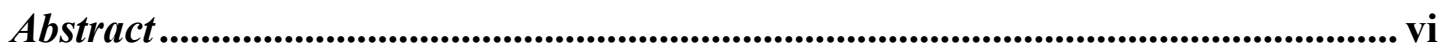

LISTA DE FIGURAS ..................................................................................... vii

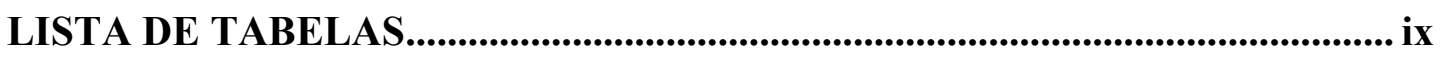

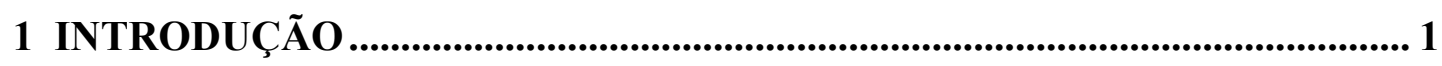

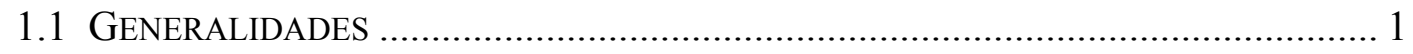

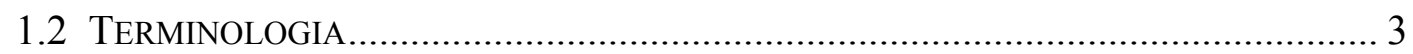

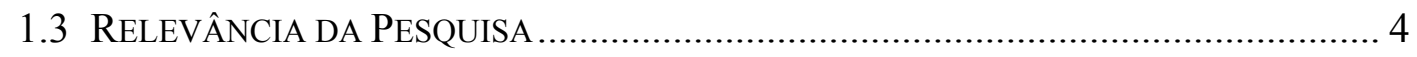

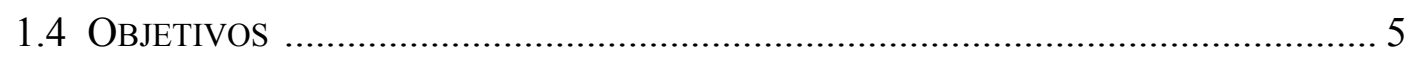

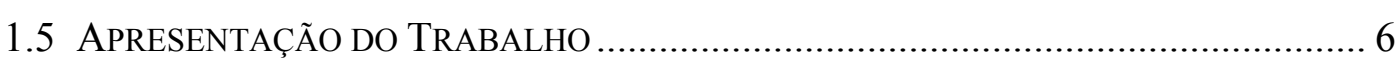

2 A PROBLEMÁTICA DOS RESÍDUOS NO BRASIL ......................................... 7

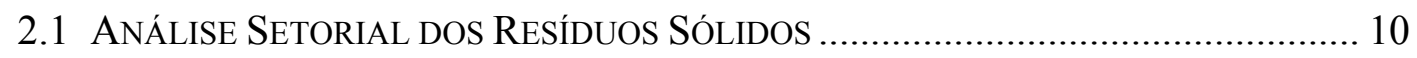

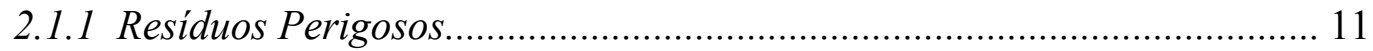

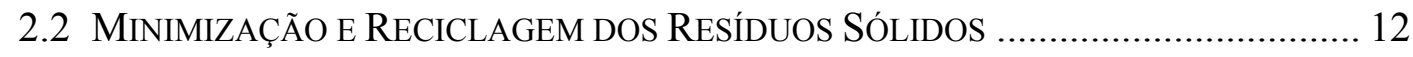

2.2.1 Disposição dos Resíduos Sólidos (Aterros)............................................. 13

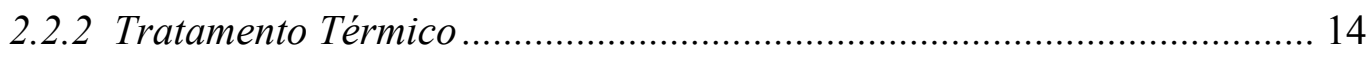

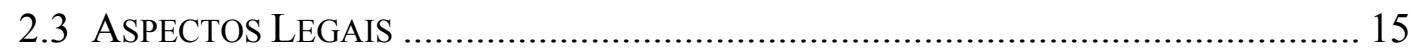

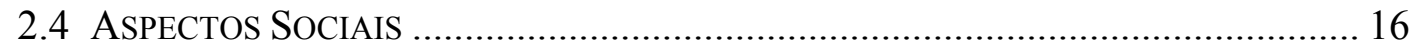

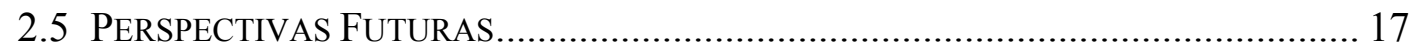

3 UMA ABORDAGEM SOBRE OS RESÍDUOS SÓLIDOS INERTES: USINAS E UTILIZAÇÕES .......................................................................... 19

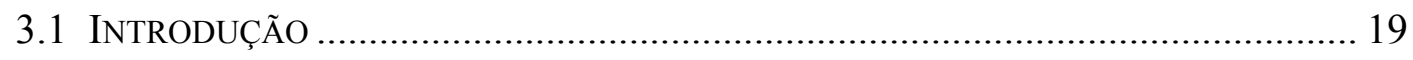

3.2 Algumas Usinas de Reciclagem do BrasiL .......................................... 20

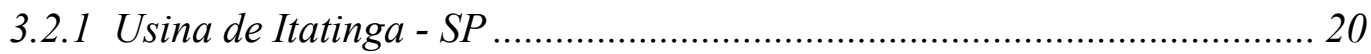

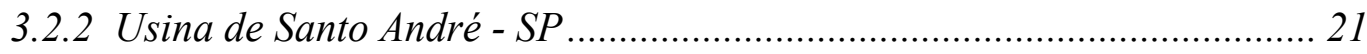




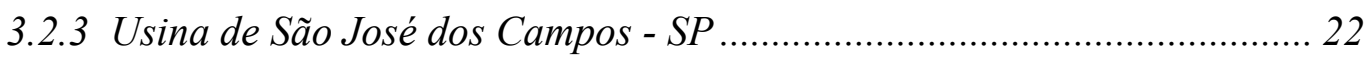

3.2.4 Usina de Ribeirão Preto - SP .................................................................... 22

3.2.5 Usina de Belo Horizonte - MG ............................................................... 25

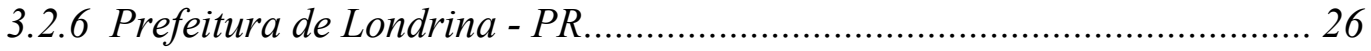

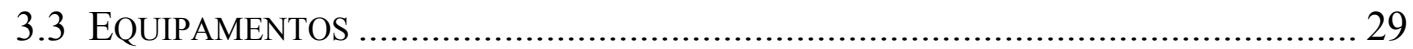

3.3.1 Equipamentos de Grande Porte .............................................................. 29

3.3.2 Equipamentos de Pequeno Porte ….......................................................... 30

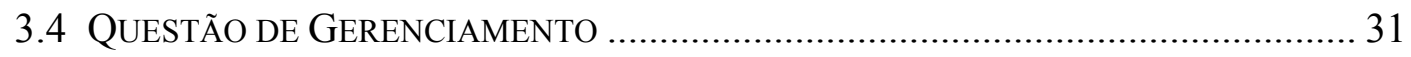

3.5 Algumas ReferênCias de AplicaÇÕEs de Material ReCiClado na

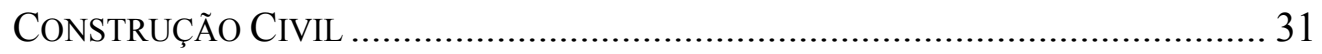

3.5.1 Leitos de Vias Públicas e Estradas ............................................................ 31

3.5.2 Concretos para Construção Civil......................................................... 32

\section{CARACTERÍSTICAS DOS MATERIAIS NATURAIS E RECICLADOS} UTILIZADOS NA PESQUISA ...................................................................... 37

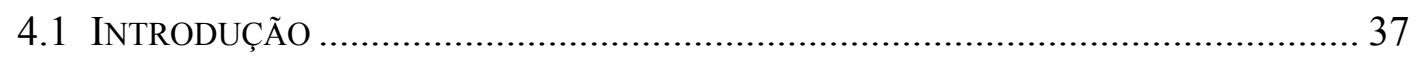

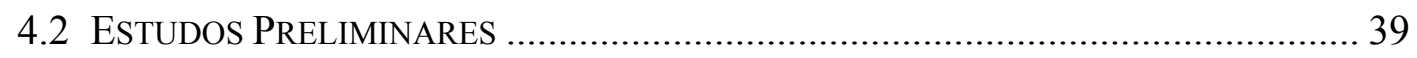

4.2.1 Coleta de Amostras do Entulho Reciclado................................................ 39

4.2.2 Caracterização Granulométrica do Material Reciclado ......................... 40

4.2.3 Caracterização Qualitativa do Material Reciclado.................................. 42

4.3 Estudo de Dosagem E VERIFICAÇão dE RESISTÊnCIA .................................. 44

4.3.1 Características Físicas dos Agregados................................................. 45

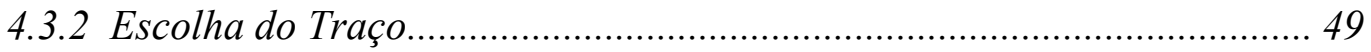

4.3.3 Verificação da Resistência dos Concretos Preparados com Material

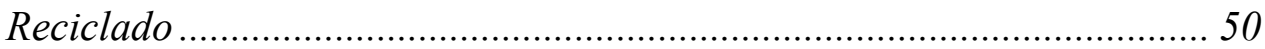

4.4 Coleta da Amostra Representativa do Entulho Reciclado da Usina

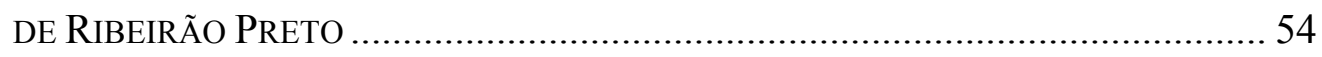

4.4.1 Determinação Granulométrica do Entulho Reciclado............................. 54

4.4.2 Natureza da Composição do Entulho Reciclado...................................... 59

4.4.3 Características Físicas dos Agregados Graúdos Reciclados Utilizados.. 61 
5 INFLUÊNCIA DO AGREGADO GRAÚDO RECICLADO NA PERDA DO ABATIMENTO DO CONCRETO FRESCO E NAS PROPRIEDADES MECÂNICAS DO CONCRETO ENDURECIDO .......................................... 64

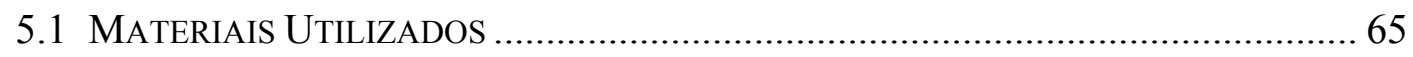

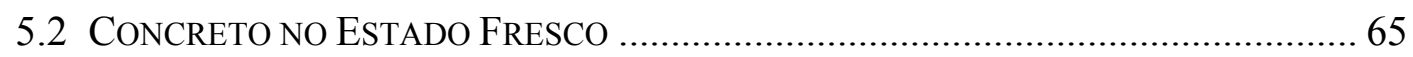

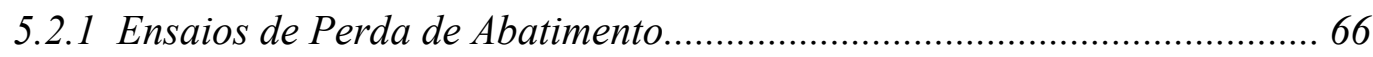

5.2.2 Massa Específica do Concreto Fresco................................................... 70

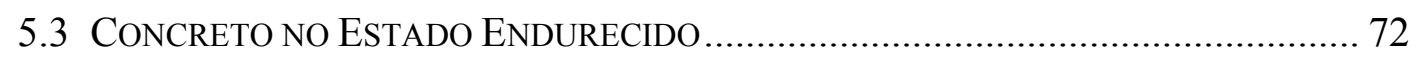

5.3.1 Ensaios de Resistência à Compressão com Determinação do Módulo de

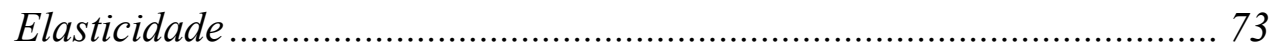

5.3.2 Ensaio de Resistência à Tração ................................................................. 75

5.4 ResistÊNCIA À ABrasÃo do CONCRETO COM AgREGAdo GRAúdo RECICLAdO80

\section{APLICAÇÃO DE CONCRETO COM AGREGADO RECICLADO NA} FABRICAÇÃO DE PAINÉIS LEVES DE VEDAÇÃO ............................... 82

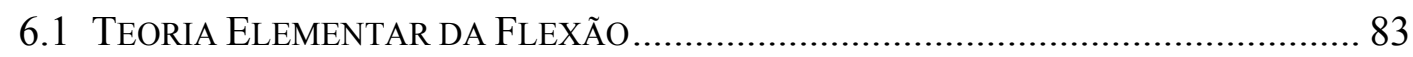

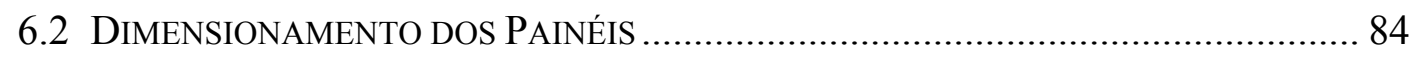

6.2.1 Momento Fletor de Fissuração .................................................................. 85

6.2.2 Verificação do Estado de Deformação Excessiva..................................... 87

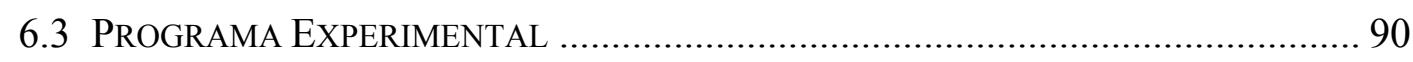

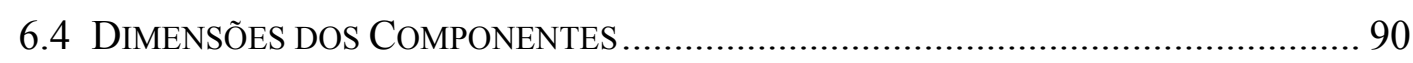

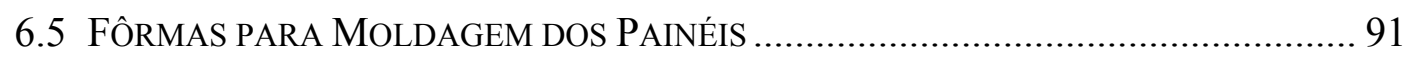

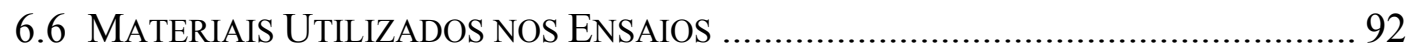

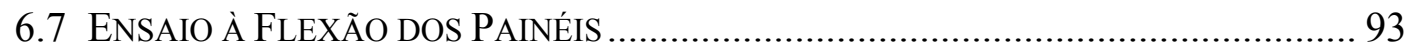

6.7.1 Moldagem, Adensamento e Cura …....................................................... 93

6.7.2 Esquema Estático e de Carregamento ..................................................... 94

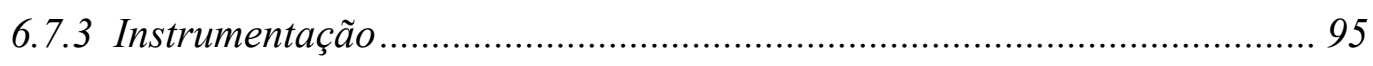

6.7.4 Ensaio de Avaliação do Comportamento à Flexão dos Painéis ............... 96 
7 APRESENTAÇÃO DOS RESULTADOS .................................................99

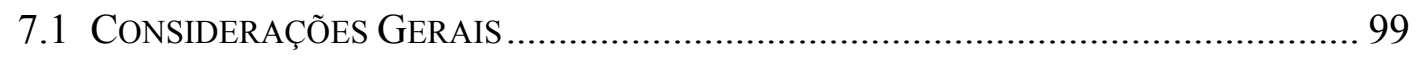

7.2 APRESENTAÇÃO E DiscuSSÃo dos RESULTAdOS ........................................... 100

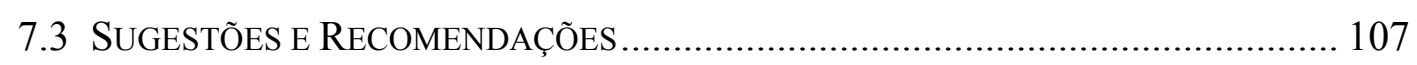

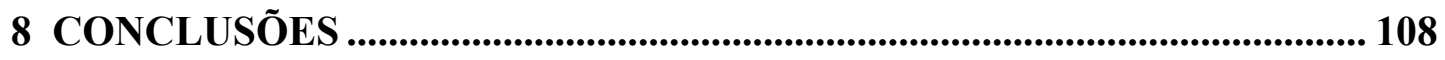

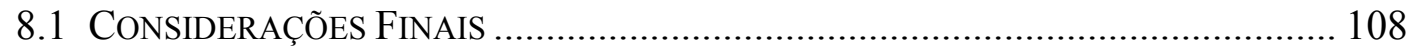

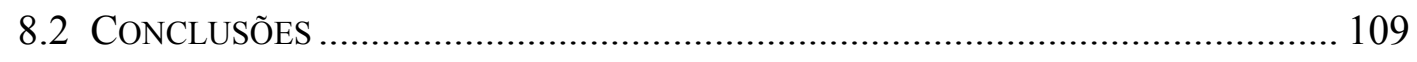

REFERÊNCIAS BIBLIOGRÁFICAS ........................................................... 111 


\section{RESUMO}

Este trabalho investiga o potencial de utilização do entulho de construção e demolição, C \& D, triturado na estação de reciclagem de entulhos de Ribeirão Preto - SP, como agregado graúdo no preparo de concretos de baixa e média resistências. A utilização da fração graúda, compreendida entre $4,8 \mathrm{~mm}<\mathrm{D}_{\text {máx }}<19,0 \mathrm{~mm}$, para substituir parcialmente ou totalmente o agregado graúdo graduado como brita $0 \mathrm{e}$ brita 1 (NBR 7211/82), pode resultar em uma significativa economia na execução de componentes urbanos e habitacionais para construções de interesse social. $O$ presente trabalho apresenta as características granulométricas e físicas, dos agregados reciclados, em comparação com as do agregado natural, usado como referência. Os resultados obtidos na substituição, parcial (50\%) e total $(100 \%)$, do agregado natural graduado como brita 1 e brita 0 , utilizados na região de Ribeirão Preto, pelo reciclado graúdo da mesma faixa granulométrica, também são apresentados. A influência do agregado reciclado na perda do abatimento do concreto fresco e nas propriedades mecânicas do concreto endurecido, foram investigadas. Finalmente, realizou-se avaliação de desempenho à flexão em painéis leves de vedação, com a finalidade de se obter uma aplicação prática ao estudo desenvolvido. Concluiu-se, assim, pela viabilidade do emprego do agregado graúdo reciclado em substituição, total ou em parte, do equivalente natural em concretos estruturais de baixa resistência.

Palavras chave: $C \& D$, resíduos, reciclagem de entulhos, concreto com agregado graúdo reciclado. 


\section{Abstract}

This dissertation researches the potential of the use of construction and demolition debris $(C \& D)$, crushed in the recycling station of Ribeirão Preto$\mathrm{SP}$, as coarse aggregate to make concrete of low and medium strenght. The use of coarse fraction, 4,8 $\mathrm{mm}<$ Dmax $<19,0 \mathrm{~mm}$, substituting, partial or totally the natural aggregate, as recommended in NBR 7211/82, can result in a significant economy on the production of urban components and for social interest constructions. The present work presents the physical and granulometric characteristics of the recycled aggregate, comparing with the natural one, used as reference. Experimental results are showed and compared. The influence of recycled aggregate on the loss of the slump of fresh concrete and on the mechanical properties of harden concrete were analyzed.

Finally, the flexural behavior of a model of panels was evaluated.

Keywords: C\&D, debris, recycled coarse aggregate, concrete 


\section{LISTA DE FIGURAS}

Figura 2.1 - Divisão do Índice de Desenvolvimento Humano no Brasil ..................... 9

Figura 3.1 - Vista geral da Usina de Rciclagem de Ribeirão Preto ........................... 23

Figura 3.2 - Calha que alimenta o transportador de correia..................................... 23

Figura 3.3 - Eletroímã para retirada de metais ferrosos ........................................... 24

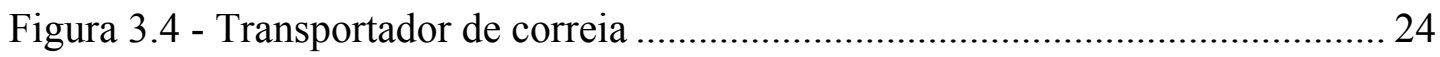

Figura 3.5 - Área de estocagem de material............................................................. 25

Figura 3.6 - Vista geral da Usina de Reciclagem de Londrina - PR com 2 britadores

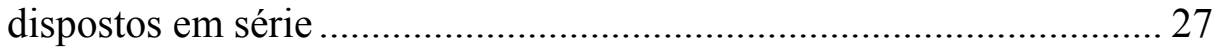

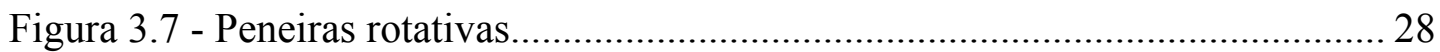

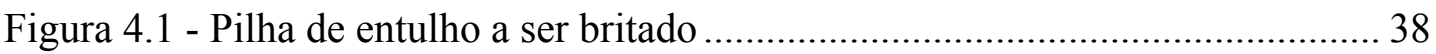

Figura 4.2 - Pilha de entulho após processo de britagem........................................ 38

Figura 4.3 - Curva granulométrica da amostra de entulho coletada em nov/96 ........ 41

Figura 4.4 - Gráficos comparativos das curvas granulométricas do entulho ............. 41

Figura 4.5 - Gráfico da composição do entulho reciclado ......................................... 43

Figura 4.6 - Fração granulométrica da amostra de entulho coletada em jan/97 ........ 44

Figura 4.7 - Curva granulométrica do agregado graúdo natural: $\mathrm{D}_{\text {máx }}=19,0 \mathrm{~mm} \ldots . .46$

Figura 4.8 - Curva granulométrica do agregado graúdo natural: $\mathrm{D}_{\operatorname{máx}}=9,5 \mathrm{~mm} \ldots \ldots .46$

Figura 4.9 - Curva granulométrica do agregado miúdo ......................................... 48

Figura 4.10 - Curva granulométrica da amostra coletada em abril/97: Bica corrida. 55

Figura 4.11 - Curvas granulométricas comparativas do entulho recicldo: Usinas de Ribeirão Preto e Londrina ................................................................ 56

Figura 4.12 - Gráficos comparativos das frações granulométricas do entulho reciclado

Figura 4.13 - Curva granulométrica do agregado graúdo reciclado:

$\mathrm{D}_{\text {máx }}=19,0 \mathrm{~mm}$ 58

Figura 4.14 - Curva granulométrica do agregado graúdo reciclado:

$$
\mathrm{D}_{\text {máx }}=9,5 \mathrm{~mm}
$$

Figura 4.15 - Gráfico da natureza da composição do agregado graúdo reciclado, coletado em bica corrida (abr/97). 
Figura 4.16 - Gráfico comparativo da natureza da composição dos agregados graúdos reciclados (bica corrida)

Figura 4.17 - Natureza da composição do agregado graúdo reciclado:

$$
\mathrm{D}_{\text {máx }}=19,0 \mathrm{~mm}
$$

Figura 4.18 - Natureza da composição do agregado graúdo reciclado:

$$
\mathrm{D}_{\text {máx }}=9,5 \mathrm{~mm}
$$

Figura 5.1 - Curvas de perda do abatimento individuais e comparação entre as curvas. Concretos com agregados graúdos com graduação 9,5 mm < D < 19,0 mm

Figura 5.2 - Curvas de perda do abatimento individuais e comparação entre as curvas. Concretos com agregados graúdos com graduação $4,8 \mathrm{~mm}<\mathrm{D}<9,5 \mathrm{~mm}$ 68

Figura 5.3 - Comparação entre gráficos Tensão $\times$ Deformação 74

Figura 5.4 - Aparato para ensaio à flexão 76

Figura 5.5 - Gráfico comparativo de resistência à tração: $\mathrm{D}_{\text {máx }}=19,0 \mathrm{~mm}$............... 79

Figura 5.6 - Gráfico comparativo de resistência à tração: $\mathrm{D}_{\text {máx }}=9,5 \mathrm{~mm}$................. 80

Figura 6.1 - Esquema de solicitação - Estádio Ib (seção simplificada) ...................... 86

Figura 6.2 - Dimensões do painel e da seção típica 91

Figura 6.3 - Posicionamento do painel: (a) encontro no meio da parede; (b) encontro no canto da parede

Figura 6.4 - Arranjo da armadura no painel 92

Figura 6.5 - (a) fôrma do painel com armadura colocada; (b) preenchimento das nervuras; (c) fôrma totalmente preenchida. 94

Figura 6.6 - Esquema estático e de carregamento do painel 95

Figura 6.7 - Aparelhagem para aplicação de força 95

Figura 6.8 - Localização dos transdutores elétricos no painel ensaiado 96

Figura 6.9 - Aparato de ensaio à flexão com detalhe do apoio móvel 97

Figura 7.1 - Gráfico Força $\times$ Deslocamento transversal, para os 3 tipos de painéis 101 Figura 7.2 - Gráfico Tensão $\times$ Deformação: (a) aos 7 dias $\quad$ (b) aos 28 dias 105 


\section{LISTA DE TABELAS}

Tabela 2.1 - Divisão do Lixo no Brasil ....................................................................... 7

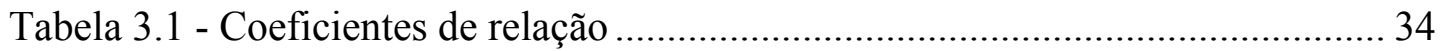

Tabela 4.1 - Abertura das peneiras (NBR 7217/87) ................................................. 40

Tabela 4.2 - Faixas granulométricas (classificação comercial) ................................ 40

Tabela 4.3 - Natureza da composição do reciclado coletado em nov/96 ................... 42

Tabela 4.4 - Caracterização granulométrica do entulho ........................................... 44

Tabela 4.5 - Características físicas dos reciclados (amostra jan/97) para agregados

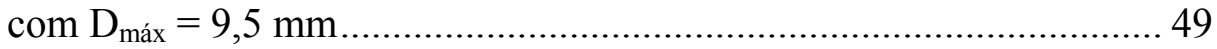

Tabela 4.6 - Quantidades utilizadas para os concretos de referência ....................... 50

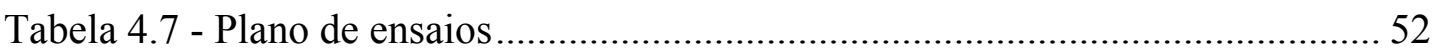

Tabela 4.8 - Resultados dos ensaios de verificação de resistência ............................ 53

Tabela 4.9 - Características físicas dos agregados graúdos reciclados ...................... 62

Tabela 4.10 - Características físicas dos agregados miúdo e graúdo naturais ........... 62

Tabela 4.11 - Absorção, índice de vazios e massa específica dos agregados ............. 63

Tabela 5.1 - Quantidade de materiais utilizada em cada concreto.............................66 66

Tabela 5.2 - Massa específica do concreto fresco e condições ambiente durante o

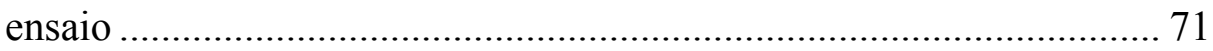

Tabela 5.3 - Número de exemplares para cada tipo de ensaio ................................. 72

Tabela 5.4 - Resistência à compressão e módulo de elasticidade.............................. 73

Tabela 5.5 - Resistência à tração............................................................................ 76

Tabela 5.6 - Relações entre valores teóricos e experimentais. ................................. 78

Tabela 5.7 - Resistência à tração aos 28 dias - Comparação entre os valores experimentais de resistência à tração por compressão diametral, RAPHAEL e proposta da revisão da NB-1/78 ................................... 79

Tabela 5.8 - Valores dos índices esclerométricos ..................................................... 80

Tabela 7.1 - Fator água/cimento e abatimento dos concretos dos painéis ................. 98

Tabela 7.2 - Corpos-de-prova cilíndricos. Média dos resultados ............................ 99

Tabela 7.3 - Absorção, índice de vazios e massa específica dos concretos .............. 100 
Tabela 7.4 - Comparação entre os momentos fletores teóricos e experimentais ..... 103

Tabela 7.5 - Comparação entre as flechas experimentais e teóricos....................... 104 


\section{INTRODUÇÃO}

\subsection{Generalidades}

Um dos graves problemas urbanos atuais, não só das grandes cidades, é a geração e a disposição de resíduos sólidos provenientes de construções e demolições, refletindo diretamente na qualidade ambiental dos espaços urbanos dos municípios.

A construção civil, atividade básica em qualquer economia, vem enfrentando a era da redução de gastos, já que jazidas de materiais de construção, em diversos países, encontram-se exauridas e cada vez mais os custos de transporte, de lugares mais distantes, estão aumentando. Assim, países como Estados Unidos, Alemanha, França, Canadá e tantos outros (e mais recentemente o próprio Brasil, porém num ritmo bem menos acelerado), avançam no estudo de tecnologias e métodos de recuperação de recursos naturais, como medidas eficazes tanto para obtenção de matéria-prima como no combate aos desperdícios, tão freqüentes nas obras de construção civil, principalmente nas de técnicas artesanais como é o caso do Brasil.

Nas últimas décadas estudos têm apresentado bons resultados na utilização de materiais naturais, como bambu, fibras vegetais de côco e sisal, bagaço de cana-de-açúcar, casca de arroz, etc., na produção de concretos e argamassas visando o barateamento do produto final, como também no reaproveitamento de resíduos sólidos inorgânicos, dos mais variados setores em que se apresentam, como cinzas volantes, escória de carvão, entre outros, e mais recentemente, atenções têm se voltado para o próprio resíduo da construção civil. 
Ao entulho, como é popularmente denominado o resíduo de construção e demolição, sempre foi dado o mesmo tratamento dispensado ao lixo domiciliar, ou pior, e o resultado pode ser visto nos bota-fora clandestinos e na degradação das áreas urbanas.

Recentemente, um processo de conscientização ambiental, aliada à necessidade de redução de custos, vem se instalando no país, refletindo-se na indústria da construção civil que através da implantação de programas de qualidade, procura diminuir a geração de rejeitos, ou mesmo reaproveitá-los no próprio canteiro de obra. Felizmente o reflexo atingiu também algumas administrações municipais, de cidades de grande e médio portes que, procurando solucionar o problema, estão instalando usinas de processamento de entulho para a reutilização do material reciclado, como por exemplo em pavimentação urbana, fabricação de componentes de construção (p. ex. guias, sargetas, etc.) e outras aplicações.

No Brasil, já existem usinas recicladoras em algumas cidades com São Paulo e Londrina, no Paraná. Uma das primeiras a serem implantadas foi a usina de Itatinga, no bairro de Santo Amaro na cidade de São Paulo. Devido a algumas falhas de concepção e planejamento, como por exemplo grandes distâncias das regiões centrais da cidade, elas acabaram por se tornar um tanto quanto ociosas, em relação à sua produtividade. Outros exemplos, entretanto, tiveram um melhor planejamento e estudos mais aprofundados para sua implantação, como no caso da cidade de Belo Horizonte, MG, que, com um programa amplo de reciclagem de entulho na cidade, deu início à instalação de quatro usinas de reciclagem espalhadas em pontos estratégicos, previamente definidos. O procedimento estendeu-se também com sucesso para mais duas cidades no estado de São Paulo; São José dos Campos e Ribeirão Preto.

Tomando como estudo de caso a cidade de Ribeirão Preto - SP, estima-se que a geração de resíduos de construção e demolição gire em torno de 970 toneladas/dia, representando $67 \%$ de participação no total de resíduos sólidos gerados diariamente, resultando no rápido esgotamento das áreas de disposição e bota-fora permitidos, PINTO (1995).

Nesse cenário, a reciclagem surge como uma poderosa arma para combater o problema do entulho, tornando-o novamente utilizável e, particularmente no próprio setor da construção civil, onde há grande potencialidade de absorção desses resíduos. A reciclagem pode ser entendida como sendo a "arte" de se reaproveitar produtos ou materiais que resultaram de algum processo produtivo, tornando-os novamente úteis, podendo-se manter ou não as 
mesmas características do material de origem. Portanto, a reciclagem devolve a condição de matéria-prima às montanhas desordenadas de sobras de materiais de construção.

\subsection{Terminologia}

Com o objetivo de homogeneizar a terminologia técnica a ser utilizada no presente trabalho, apresenta-se a seguir algumas definições provenientes do aglutinamento de termos encontrados em normas técnicas (NBR 10.004/87 "Resíduos Sólidos - Classificação") e em literatura específica. Em particular tomaremos como base as definições apresentadas no documento que fez parte do "Programa para Redução de Problemas Ambientais e Reciclagem de Resíduos da Construção na Cidade de Ribeirão Preto", elaborado pela I\&T Informações e Técnicas em Construção Civil, descritas abaixo:

\section{Resíduos Sólidos:}

São os resíduos nos estados sólidos e semi-sólidos, que resultam da atividade de uma comunidade, com origem industrial, doméstica, hospitalar, comercial, agrícola, de serviços e de varrição. Devem ser distinguidos em 3 classes: Classe I - resíduos perigosos; Classe II - resíduos não inertes; Classe III resíduos inertes.

\section{Resíduos Sólidos Urbanos:}

São resíduos sólidos gerados no ambiente urbano.

\section{Resíduos da Construção Civil:}

São os resíduos inertes, do tipo Classe III, que são gerados nas atividades de construção e demolição de edificações ou ambientes urbanos. Incluem o solo retirado nos processos de desaterro e os resíduos, restos ou aparas dos diversos materiais utilizados na atividade construtiva. Enquanto resíduos devem ser classificados como sub-produtos ou rejeitos.

\section{Deposição de Resíduos Sólidos:}

Atividade intermediária, anterior à destinação final de resíduos sólidos (quase sempre é realizada de forma aleatória e ilegal).

\section{Disposição de Resíduos Sólidos:}

Atividade intermediária ou final, com manejo e arranjo corretos dos resíduos. 


\subsection{Relevância da Pesquisa}

Com a estabilidade econômica a atividade da construção civil cresceu consideravelmente, e com ela a produção de materiais de construção. Por conseguinte a geração de rejeitos sólidos de construção e demolição, provenientes dos mais diversos agentes, aumentou assustadoramente.

A construção civil é um dos setores que mais gera resíduos sólidos, considerando-se proporcionalmente o seu produto final. Estatísticas apontam que no Brasil as perdas chegam a atingir $20 \%$ a $30 \%$ da massa de material de construção que entra em cada obra. Segundo o arquiteto Tarcísio de Paula Pinto, da I \& T Informações e Técnicas em Construção Civil, "tudo começa com processos construtivos que resultam em desperdícios". Sem contar que muitos dos defeitos e falhas encontrados nas construções são causados ainda na própria fase de projeto, CALAVERA (1991).

A grande necessidade de redução de custos na construção, aliada ao déficit habitacional existente atualmente em nosso país, bem como a escassez de recursos naturais a que o mundo vem caminhando nos últimos tempos, faz com que o reaproveitamento dos recursos disponíveis seja essencial à sobrevivência futura de nosso planeta.

A esta realidade, acrescenta-se ainda a constatação de que as jazidas de agregados naturais para concreto estão se tornando mais escassas, fazendo com que se busque este material em lugares cada vez mais distantes, aumentando consideravelmente o custo total da construção, com reflexo, inclusive, nas obras destinadas às classes de baixa renda. Segundo dados de 1997 da Coordenadoria da Estação de Reciclagem de Ribeirão Preto, D.E.R.M.U.R.P.- (Departamento de Estradas de Rodagem de Ribeirão Preto), o custo de reciclagem, operando com capacidade total, é de U\$3,94/t contra U\$ 5,37/t, para gerenciamento das deposições irregulares de entulho, o que já seria por si só, uma economia considerável.

Além da economia, existe o fator ambiental onde a deposição indiscriminada, e muitas vezes clandestina, de entulhos de construção na malha urbana acarreta a degradação de áreas e vias urbanas bem como na rápida saturação dos aterros de materiais inertes, quando existentes. Não bastando isto, tem-se ainda rios e córregos assoreados, bueiros e galerias entupidos, (e consequentemente enchentes), tornando os ambientes propícios para proliferação de ratos, insetos e outros animais transmissores de doenças. 
Por fim ressalta-se o fator social, onde se tem a possibilidade de geração de novos empregos, através da instalação e montagem de usinas de reciclagem com centralização de recebimento de materiais, e de realizar programas de incentivo à captação e utilização do entulho.

A reciclagem vem estabelecer novas, efetivas e realistas soluções a alguns dos nossos problemas de engenharia, utilizando-se de materiais locais e de baixo custo, provendo novas ferramentas para enfrentar alguns dos problemas sociais e econômicos, de peso em nosso país.

Procurando definir usos para os reciclados graúdos, como agregado para concreto, com os devidos cuidados e restrições que lhes cabem, a pesquisa pretende estabelecer recomendações técnicas e aplicações práticas e econômicas, para este novo material de construção, cujo custo por metro cúbico em bica corrida, pode chegar a aproximadamente $20 \%$ do custo do agregado natural comercial.

\subsection{Objetivos}

Os objetivos do presente trabalho são:

- Demonstrar a viabilidade da utilização da fração graúda do reciclado, como material de construção para concretos estruturais de média e baixa resistências (classe C-15), e a reutilização em aplicações mais nobres com finalidades de interesse social.

- Investigar a influência do agregado graúdo, reciclado de entulhos de construção e demolição, nas propriedades do concreto fresco e endurecido.

- Avaliar algumas características físicas dos materiais e dos concretos confeccionados com estes materiais.

- Avaliar o desempenho estrutural, à flexão, de painéis confeccionados com concretos utilizando-se a fração graúda do material reciclado como substituição parcial ou total do material natural. 


\subsection{Apresentação do trabalho}

Após uma breve introdução, justificando a importância do trabalho e apontando os objetivos básicos da pesquisa, no Capítulo 2 aborda-se a questão dos resíduos sólidos no Brasil sobre os pontos de vista de alguns aspectos, inclusive legais e sociais.

No Capítulo 3 apresenta-se algumas usinas de reciclagem no Brasil, descrevendo sumariamente seu funcionamento e tipos de equipamentos utilizados. Apresenta-se também aplicações do material entulho reciclado utilizado em concretos.

No Capítulo 4 são descritos os estudos preliminares e feita a caracterização física do material entulho reciclado, proveniente da Usina de Reciclagem de Ribeirão Preto, o qual foi utilizado em substituição total ou parcial do agregado graúdo natural para o preparo do concreto.

No Capítulo 5 analisa-se a influência do material entulho reciclado como agregado graúdo para concreto, em relação principalmente à perda do abatimento no concreto fresco e propriedades mecânicas no concreto endurecido.

O Capítulo 6 trata da aplicação do concreto com agregados reciclados em painéis leves de vedação, abordando-se os fundamentos teóricos e as considerações básicas de cálculo para análise estrutural à flexão do painel.

No Capítulo 7 são apresentados os resultados obtidos da análise estrutural do painel e comentários são feitos. As considerações finais e conclusões encontram-se no Capítulo 8. 


\section{A PROBLEMÁTICA DOS RESÍDUOS NO BRASIL}

O Brasil apresenta a maior extensão territorial dentre os países da América Latina e também a maior população. Com área superficial de $8.511 .985 \mathrm{~km}^{2}$ de extensão, está subdividido em 5 regiões com 26 estados mais Distrito Federal, que por sua vez somam 4.974 municípios; apresenta uma economia em franca evolução, passando pela transição da fase essencialmente agrícola e fornecedora de matéria-prima para uma fase de industrialização diversificada, inclusive proporcionando certa ênfase no ramo dos serviços.

Tomando como exemplo alguns dados estatísticos apresentados por MENDONÇA (1996), a produção de resíduos no país, como um todo, chega a totalizar 241.614,00 t/dia, o que significa dizer que cada brasileiro produz, o equivalente a cerca de $1,59 \mathrm{~kg}$ de lixo diariamente. Para se ter uma melhor descrição do que isto significa, essa quantia pode ser subdividida da seguinte forma, Tabela 2.1:

\section{Tabela 2.1 - Divisão do Lixo no Brasil}

Produção de Lixo no Brasil

\begin{tabular}{lcc}
\hline Residencial & $96.000,00$ & 39,7 \\
\hline Comercial & $32.055,42$ & 13,3 \\
\hline Industrial & $21.745,26$ & 9,0 \\
\hline Material Inerte & $91.813,32$ & 38,0 \\
\hline Total & $241.614,00$ & 100,0 \\
\hline
\end{tabular}

Por estas informações apresentadas, pode-se notar que a parcela de resíduos inertes chega a quase igualar-se à parcela do lixo residencial, representando 
$38 \%$ do total de lixo produzido no país. Não é à toa que as áreas de aterro têmse esgotado rapidamente gerando grandes problemas de deposição dos resíduos, orgânicos ou inertes, principalmente em grandes centros urbanos com concentração de população, como é o caso de São Paulo e vários outros municípios do Brasil.

Em nosso país, a política para o gerenciamento dos resíduos sólidos é controlada basicamente por 3 esferas governamentais; a Federal, a Estadual e a Municipal que, embora possuam objetivos muito semelhantes, nem sempre têm sido bem sucedidas, tendo seus problemas mais comuns como sendo a melhoria da qualidade dos serviços de coleta, e a procura de práticas de destino final que protejam o meio ambiente e a saúde pública, sem no entanto, acarretar em gastos de quantias exorbitantes. Vários são os fatores que contribuem para esse insucesso, dentre eles, a grande diversidade de nosso país dada à sua extensão geográfica, o variado nível econômico da população e também a necessidade de criação de políticas, regras e regulamentos específicos às suas necessidades e que ao mesmo tempo sejam compatíveis com a realidade econômica de cada região, evitando que se façam deposições inadequadas.

Considerando-se que executivamente o problema do lixo é, na maior parte das vezes, de competência da municipalidade, na prática, o que ocorre é que na maioria dos casos as soluções encontradas são totalmente empíricas, principalmente nas cidades menores ou com populações de baixo poder aquisitivo, ou em áreas rurais. A limpeza pública não está localizada entre os serviços que angariam, de imediato, "dividendos eleitorais", colocando-a num patamar secundário pelos políticos interesseiros que, avessos a investimentos em infra-estrutura, adotam muitas vezes soluções inadequadas e provisórias.

Como conseqüência imediata tem-se a caótica situação da destinação final do lixo, não só nas principais capitais mas praticamente em todo o país, que tem sido realizada de maneira improvisada e empírica. "São descargas clandestinas que agravam ainda mais a poluição ambiental, por vezes de forma irreversível devido ao volume de recursos dispensados e às técnicas necessárias para a recuperação das áreas afetadas", MENDONÇA (1996).

De acordo com um levantamento feito pelo PNUD - Programa das Nações Unidas para o Desenvolvimento e pelo IPEA - Instituto de Pesquisa Econômica Aplicada, o Brasil pode ser dividido em 3 áreas bastante diversificadas com base no IDH - Índice de Desenvolvimento Humano. Segundo os estudos apurados na pesquisa, este índice constitui-se num parâmetro da qualidade de vida e do nível de progresso de cada região do Brasil, Figura 2.1, e é formado por 3 fatores principais, apresentados a seguir e resumidamente descritos adiante: 
- indicadores de renda

- expectativa de vida ao nascer

- escolaridade

$\mathrm{Na}$ área indicada na figura como tendo maior índice de desenvolvimento, abrangendo as regiões Sudeste e Sul do país, encontram-se cidades e capitais que possuem sistemas de coleta e transporte equiparados aos existentes nos países chamados desenvolvidos. Encontra-se praticamente consolidado o uso de equipamentos compactadores mecanizados montados sobre plataforma de caminhão, fabricado totalmente no Brasil. Prefeituras como a de São Paulo e algumas empresas particulares já estão implantando sistemas computadorizados de levantamento e controle dos serviços de coleta e principalmente de pesagem dos resíduos quando do seu destino final. A necessidade de padronização também atinge os serviços contábeis, responsáveis pelos pagamentos das faturas. Mesmo assim, nessas regiões ainda se encontram localidades onde a tração animal é largamente utilizada nos serviços de coleta, geralmente nas pequenas cidades.

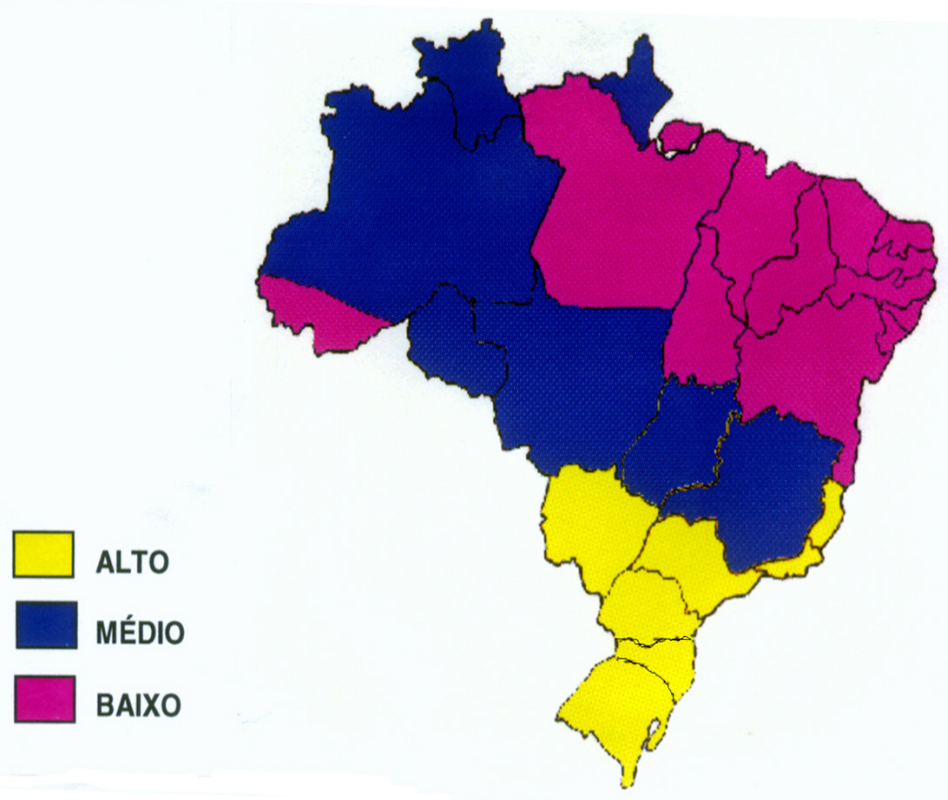

\section{Figura 2.1 - Divisão do Índice de Desenvolvimento Humano no Brasil}

$\mathrm{Na}$ área indicada como tendo índice de desenvolvimento intermediário, abrangendo as regiões Norte e Centro Oeste do país, os sistemas de gerenciamento de resíduos sólidos, mesmo em algumas capitais estaduais, variam de aceitável a abaixo do padrão, de acordo com o determinado na pesquisa. O mesmo pode-se dizer da região Nordeste do país, que corresponde 
à área que apresenta baixo índice de desenvolvimento humano, por localizarse em áreas de secas e infra-estrutura deficiente.

Essas diferenças no desenvolvimento econômico acarretam estilos de vida diferenciados que se refletem diretamente na quantidade e diversidade dos resíduos sólidos gerados. Por exemplo, nas regiões mais ricas onde é mais comum a utilização de alimentos preparados e semi-preparados industrialmente, existe menor quantidade de material orgânico nos resíduos e um enorme volume de recicláveis do tipo embalagens plásticas, vidros e metais. Por outro lado, nas regiões mais pobres, o material orgânico é predominante no lixo domiciliar, pelo fato de que a maior parte dos alimentos consumidos são preparados pelas pessoas em suas próprias casas.

Dessa forma, o resíduo sólido pode até ser considerado como um indicador sociológico, apontando as oscilações da economia, como desemprego, maior ou menor poder aquisitivo, ou ainda a evolução do poder de compra das classes mais favorecidas. Entretanto, mesmo nas regiões metropolitanas das grandes capitais, ainda existe a necessidade de se ter legislações que permitam a implantação de soluções conjuntas entre os municípios, permitindo o aproveitamento mais racional das áreas disponíveis para aterros.

Na maioria das vezes as soluções utilizadas pelos municípios são os lixões a céu aberto, sem qualquer tipo de controle ambiental, que equivocadamente são chamados de aterros sanitários, cuja definição dada por MENDONÇA (1996) consiste no "confinamento da maior quantidade de resíduos no menor espaço possível, com o mínimo de dano ao meio ambiente".

\subsection{Análise Setorial dos Resíduos Sólidos}

A problemática dos resíduos sólidos é tão diversificada, que se torna necessário recorrer a uma análise setorial, mesmo que simplificada, a fim de caracterizá-la de forma mais objetiva na procura de soluções adequadas.

É necessário que se faça um levantamento mais intensificado dos volumes e características dos resíduos sólidos, definindo-os corretamente, a fim de se estabelecer padrões mínimos dos serviços de coleta e transporte, ampliando as áreas atendidas por tais serviços, com redução de custos, aumentando a segurança dos trabalhadores envolvidos e a saúde pública, bem como melhorando a proteção ao meio ambiente. 
A maioria da legislação existente atualmente considera satisfatório o fato de contemplar apenas o lado quantitativo dos resíduos, em função da coleta do lixo, que pode ser resumida em determinar tarifas adicionais para as coletas dos volumes excedentes, geralmente constituído por 100 litros por unidade produtora, numa tentativa de prover um certo reforço à tarifa básica cuja cobrança é efetuada juntamente com o IPTU do imóvel, MENDONÇA (1996). De qualquer forma, o que se tem visto é que sempre foi necessário subsidiar a operação de limpeza pública.

\subsubsection{Resíduos Perigosos}

Esses tipos de materiais são resíduos industriais que foram contaminados ou que contém agentes contaminantes, ou ainda resíduos orgânicos infectados. Também neste caso existe a necessidade de se fazer o levantamento de práticas de gerenciamento, bem como dos aspectos legais, econômicos e tecnológicos, e definir prioridades. "Alguns órgãos estaduais que cuidam do meio ambiente já possuem elementos tanto legais como técnicos para exercerem um controle efetivo, mas ainda se ressentem da falta de recursos adequados para implementação de um sistema uniforme para o gerenciamento", MENDONÇA (1996).

O que ocorre normalmente é que o próprio produtor é responsável pela disposição final do resíduo, após ter passado por algum meio de neutralização dos princípios ativos contaminantes, quer sejam através de filtros ou meios química ou fisicamente atuantes, geralmente realizado por firmas particulares com supervisão e controle dos órgãos estaduais encarregados pela preservação do meio ambiente.

Não existe, por hora, uma legislação específica para combater esse tipo de problema, que vem sendo ignorado até mesmo pela própria população, que lança materiais contaminantes (p.ex. pilhas, baterias, tintas, e demais produtos que possuem princípios químicos ativos ou até mesmo metais pesados como o mercúrio), sem o menor cuidado, juntamente com o lixo domiciliar. "Essa ocorrência vem afetar diretamente o composto orgânico produzido nas usinas, podendo eventualmente exigir um controle mais apurado em sua utilização", MENDONÇA (1996). 


\subsection{Minimização e Reciclagem dos Resíduos Sólidos}

Da análise comparativa, considerando-se as experiências e tendências de países desenvolvidos, finalmente depreende-se que nos planos de gerenciamento dos resíduos sólidos existe a necessidade de se considerar a possibilidade de existirem programas de minimização de lixo e de reaproveitamento dos mesmos.

Com relação ao reaproveitamento, uma boa parte das capitais do Brasil já possui instalações para recuperação de materiais, utilizando a própria mão-deobra local, chamada em algumas regiões e localidades de "catadores", ou com alguma mecanização com sistemas simples, geralmente esteiras rolantes, prensas para papel, papelão ou latas.

Com o surgimento dos recipientes tipo PET - Poli-Etileno Tereflatado, algumas indústrias estão se especializando na reciclagem e fabricação de outros produtos a partir deste material, e já estão se estabelecendo em algumas cidades, como São Paulo por exemplo.

Com base em estudos realizados por MENDONÇA (1996), a reciclagem de materiais ainda é considerada uma atividade cíclica devido a alguns fatores tais como: pequena capacidade de absorção, para alguns materiais, pelas indústrias; grande necessidade de investimentos de capitais, e ainda, ao risco mercadológico. Considera-se, porém, que é um ramo da industrialização que está em ascensão, contendo uma disponibilidade crescente de matéria-prima de alta qualidade e que conta com a opinião pública a seu favor, alavancada por ampla divulgação e esclarecimentos mais detalhados.

Uma solução bastante apropriada para este problema consiste em que as municipalidades deleguem à empresas particulares este ramo de atividade em caráter comercial, e limitem-se à supervisão e controle no que diz respeito, principalmente, à degradação do meio ambiente, e garantindo condições mínimas de sobrevivência aos catadores, no que se refere ao aspecto social.

As autoridades públicas não deveriam gastar esforços para tentar se transformar em "comerciantes" de materiais recicláveis e matéria-prima secundária, mas sim preocuparem-se, concentradamente, em resolver os problemas que há muito mais tempo já existem e ainda são debilitados como a saúde pública, problemas de ordem sanitária, ou mesmo problemas de cunho social decorrentes do acondicionamento, coleta, transporte e destino final dos resíduos sólidos urbanos. 
Os resíduos sólidos domésticos tornam-se mais fáceis de serem reciclados devido a um processo chamado compostagem, que tecnicamente é possível devido ao alto teor de umidade e alta porcentagem de matéria orgânica existente em sua composição. Muitas instalações de compostagem natural têm sido construídas utilizando-se métodos de compostagem natural acelerada do material orgânico, que passa por um "beneficiamento" para remoção de inertes e recicláveis por métodos mecânicos e manuais. Com isso o composto produzido não fica agressivo ao meio ambiente e por ser um produto de baixíssimo risco, proporciona um gradual aumento na sua utilização e inclusive, como conseqüência, um aumento também no número de instalações que poderiam ser construídas.

\subsubsection{Disposição dos Resíduos Sólidos (Aterros)}

A técnica de aterramento sanitário é bastante difundida e praticada, porém existem muitas cidades, principalmente aquelas cuja população possui baixa renda, onde esta técnica ainda é ignorada. No Brasil existem pouquíssimos aterros sanitários que estejam operando dentro das normas técnicas e muitas vezes, a aquisição de um equipamento tipo trator para realizar o recobrimento diário do lixo ainda está acima dos recursos disponíveis do município.

Com isso, os depósitos de resíduos sólidos acabam por se tornarem criadouros de animais, sendo infestados por insetos e roedores. Colaborando para agravar ainda mais a situação, a falta de cuidado técnico permite que, com as chuvas, as águas superficiais e posteriormente as subterrâneas se tornem poluídas e, na errônea suposição de que na queima do lixo depositado surja uma solução barata, o ar atmosférico também é contaminado com grandes poluentes.

Por outro lado, as grandes capitais deparam-se com a dificuldade de se obter locais amplos e apropriados para aterros (sanitários ou de inertes), criando a assim chamada "síndrome N.I.M.B.Y. (Not in my back yard - não no meu quintal) devido à conturbação que deixa as áreas utilizáveis ao lado de áreas residenciais emergentes", MENDONÇA (1996).

Existe a necessidade de se obter procedimentos-padrão para o treinamento do pessoal de operação, estabelecendo-se uma qualidade aceitável de trabalho em qualquer tipo de aterro. Pode-se assim, minimizar o nível de incômodo e perturbação, tanto à vizinhança local como ao próprio meio ambiente, permitindo-se que haja um relacionamento e interação mais harmônicos entre 
população e meio ambiente. Uma das maneiras de se viabilizar isto, é enfatizar a utilização futura das áreas dos aterros como local de lazer para a comunidade da circunvizinhança, ou mesmo a recuperação do local mediante remoção dos materiais recicláveis e mineralizados.

Um problema muito comum que se encontra nas grandes cidades é o grande distanciamento das áreas de aterro em relação aos centros urbanos, tornandose necessária a criação de estações intermediárias de coleta, denominadas "estações de transferência", ou "estações ou postos de recepção", PINTO (1996), onde os resíduos são passados dos veículos de coleta comuns para veículos com capacidades maiores, geralmente semi-reboques, que se dirigem aos aterros enquanto os coletores retornam aos seus locais de trabalho.

O problema das grandes distâncias em relação aos centros urbanos, tem ocorrido também nos últimos anos, para a parcela dos resíduos sólidos provenientes de construções e demolições (entulho de obras), que estão se tornando parte bastante significativa do volume total dos resíduos sólidos urbanos, necessitando áreas de aterros especificamente para estes materiais. Mais recentemente, atenções têm se voltado para a possibilidade de reaproveitamento dos entulhos de obras, inclusive com a instalação, em algumas cidades, de usinas de processamento, através da britagem do material. Algumas características das usinas e dos materiais por elas produzidos, serão abordados no capítulo 3 .

\subsubsection{Tratamento Térmico}

O tratamento térmico de resíduos sólidos não se constitui ainda numa opção expressiva para dar cabo aos resíduos sólidos urbanos. Apenas algumas instalações foram construídas, mas a maioria delas já foi fechada e as que permanecem funcionando são utilizadas exclusivamente para incineração de lixo hospitalar e séptico.

Até 1995 existiam 3 instalações de tratamento térmico em São Paulo; uma delas está fechada e as outras duas estão ainda em funcionamento, porém com capacidade reduzida, devido a problemas de falta de manutenção. Existe legislação federal, estadual e municipal que rege o assunto mas que, por estar com seus princípios básicos apoiados naqueles dos países desenvolvidos, acabam acarretando problemas na sua implantação por se encontrarem fora da realidade econômica de nosso país. 


\subsection{Aspectos Legais}

Em nosso país, não só os resíduos sólidos mas também os aspectos ambientais são regidos pelos 3 níveis de legislação, Federal, Estadual e Municipal. Este fato tem causado diversos motivos de atrito por causa da interferência que cada uma das partes exerce sobre a outra, não apenas nos aterros sanitários e de inertes, mas em unidades de processamento intermediário, de compostagem e de incineração, como por exemplo exigindo-se níveis elevadíssimos de pureza de efluentes gasosos de incineração, praticamente impossíveis de serem alcançados ou comprovados tecnicamente, ou ainda proibindo-se o tráfego de veículos de outros municípios dentro de seus limites, inviabilizando assim soluções conjuntas.

Em agosto do ano de 1996, o Governo Federal propôs modelos de gestão de resíduos, através do Projeto BRA/92/017 - Gestão e Tecnologia de Tratamento de Resíduos, lançado em Brasília partindo-se do planejamento integrado e articulado entre os níveis de ação governamental, em parceria com os diversos segmentos da sociedade.

Esse elemento-chave, isto é, a parceria, levaria em conta os princípios da "Agenda 21" e do "Desenvolvimento Sustentável", e interessaria ao empresariado, usuários, universidades, institutos de pesquisa, ONG's, mídia, associações de classe, parlamentares, enfim, um espectro amplo o suficiente para englobar os segmentos mais representativos da sociedade. A "Agenda 21" foi referendada na Eco 92 - Conferência das Nações Unidas sobre o Meio Ambiente e o Desenvolvimento, realizada no início de 1992 no Rio de Janeiro e contém os seguintes tópicos transcritos a seguir:

- minimização de resíduos;

- reciclagem e reutilização;

- tratamento ambientalmente seguro;

- disposição ambientalmente segura;

- substituição de matérias-primas perigosas;

- transferência e desenvolvimento de tecnologias limpas.

MENDONÇA (1996) salienta que existe a necessidade de se estabelecer uma legislação mais ampla, Federal ou Estadual, que venha regulamentar o transporte e a descarga de resíduos sólidos entre as divisas municipais, prevendo-se condições de financiamento para o custeio de recepção desses 
materiais. Já se poderia pelo menos iniciar a padronização das leis nas Áreas Metropolitanas das Grandes Cidades, viabilizando soluções conjuntas, que poderiam alcançar níveis desejáveis tanto do ponto de vista técnico, como também, e principalmente, econômico.

\subsection{Aspectos Sociais}

$\mathrm{Na}$ destinação final dos resíduos sólidos, também está envolvido o fator de âmbito social com importância representativa na comunidade, não apenas fazendo a acomodação da população de catadores, mas também proporcionando o seu treinamento a fim de aprimorar as técnicas de aproveitamento dos recicláveis, podendo-se inclusive utilizar essa mão-deobra nas instalações de reciclagem e recuperação de materiais.

De igual importância, ou ainda maior, é a participação dos órgãos públicos na implementação de políticas ecológicas e ambientais visando a sua aceitação pela sociedade, que deve ser chamada a entender e colaborar.

O estímulo de uma consciência ecológica entre a população e também entre os grandes produtores de resíduos sólidos, sejam eles de qualquer natureza, deve ser um dos objetivo prioritários, a fim de que se contribua ativa e conjuntamente para a minimização e o estabelecimento da coleta seletiva dos resíduos sólidos.

\subsection{Perspectivas Futuras}

Ao encararmos a realidade de nosso país, considerando-se os mais diversos níveis de desenvolvimento, deve-se reconhecer a extrema necessidade de se enfrentar o problema da limpeza pública de uma maneira mais profissional e técnica. "Um planejamento integrado, dentro da realidade econômica, social e técnica de cada cidade deve ser estabelecido e implantado", MENDONÇA (1996).

As estruturas administrativas das cidades encontram-se bastante arcaicas e carregadas de entraves legais, o que leva cada vez mais, a se considerar a possibilidade de privatização dos serviços públicos como alternativa viável para se colocar em prática soluções dessa natureza. Isto porque as empresas 
possuem uma visão comercial e não burocrática em relação à sistemática de suas atuações, proporcionando redução de custos e aumento de produtividade; além do mais, com a competitividade do mercado, podem oferecer maior eficiência e competência, melhorando inclusive a qualidade dos serviços. $\mathrm{O}$ papel das autoridades municipais seria única e exclusivamente de exercer fiscalização e execução de contratos, mantendo a pontualidade e regularidade da questão financeira, dando fluência à parte econômica do empreendimento.

A melhoria dos serviços e o equacionamento do problema, acarretariam por influenciar também, diretamente e de maneira positiva, a questão da saúde pública e do meio ambiente. De acordo com MENDONÇA (1996), a iniciativa privada, alcançando a estabilidade econômica e financeira, abre-se às possibilidades inovadoras de tecnologias mais modernas e avançadas que venham a melhorar a qualidade dos serviços e o atendimento ao público.

Todas estas idéias parecem muito bonitas, mas se não houver um trabalho conjunto com a população de conscientização, informação e esclarecimentos, pode haver o risco de uma reação negativa com resistência da comunidade em relação às novas idéias. Podemos citar como exemplo o caso da Usina de Reciclagem de Belo Horizonte que sofreu um atraso de mais de 15 meses na sua inauguração por causa da população estar mal informada em relação aos benefícios que a unidade traria à comunidade local.

É necessário que haja campanhas de divulgação e programas de incentivo que impulsionem a participação intensa da população. Faz-se necessário também dar ênfase a programas educacionais nas escolas de todos os níveis, mas prioritariamente nas escolas primárias para se começar a mudar a mentalidade e a maneira de encarar a situação dos resíduos e a importância da colaboração coletiva para que, no futuro, a sociedade possa colher algum resultado no decorrer das próximas décadas.

Finalmente, talvez a parte mais importante caiba aos poderes públicos de estabelecer uma legislação abrangente, uniforme e que leve em conta as peculiaridades das diversas regiões, MENDONÇA (1996). Assim, os sistemas de gerenciamento dos resíduos sólidos tornam-se capazes de se adequar às realidades fiscais, políticas, econômicas e financeiras das comunidades, não somente das mais desenvolvidas mas também, e principalmente, daquelas comunidades menos providas de infra-estrutura urbana.

Qualquer que seja o processo utilizado, a destinação final dos resíduos deve ser considerada como prioritária em qualquer sistema de gerenciamento de resíduos sólidos, seja municipal ou particular. O desafio maior, no atual estágio de desenvolvimento técnico e na capacidade de investimento das 
cidades, é criar condições para a implantação de aterros "que sejam realmente sanitários e que não agridam ao meio ambiente”, MENDONÇA (1996).

A questão dos resíduos sólidos e dos locais para sua disposição, bem como programas de incentivo à reciclagem de materiais passíveis de tal processo, ainda está bem longe de ser totalmente controlada e solucionada. A parceria com a iniciativa privada parece ser a alternativa mais concreta e segura para tentar evitar conseqüências irreversíveis em termos de impacto ambiental. Com isto, abre-se caminho para se acabar, ou pelo menos diminuir com os lixões e com a dramática situação que vem se estabelecendo nas pequenas cidades e se alastrando nas grandes metrópoles.

Com a problemática estabilizada dos pontos de vista técnicos e legais, resta incentivar órgãos internacionais relacionados ao desenvolvimento, saúde pública e meio-ambiente, a investirem financeiramente na construção de instalações com elevado custo. Por outro lado, não é só investimento financeiro a grande necessidade do setor, mas juntamente com estes recursos, a transferência de tecnologia torna-se imprescindível para permitir que se possa implementar o adequado gerenciamento dos resíduos sólidos.

Da fração dos resíduos sólidos classificados como material inerte, proveniente do entulho de construção e demolição, já se tem iniciado o tratamento para "beneficiamento" em Usinas de Reciclagem em diversas cidades brasileiras e seus produtos utilizados genericamente. A respeito das usinas e algumas aplicações dos materiais resultante desse "beneficiamento" será abordado no capítulo seguinte. 


\section{UMA ABORDAGEM SOBRE OS RESÍDUOS SÓLIDOS INERTES: USINAS E UTILIZAÇÕES}

\subsection{Introdução}

A reciclagem não é propriamente uma novidade. Tem-se notícias de que, segundo CSTB Magazine (1993), os antigos romanos no ano 19 a.C. utilizaram cacos de tijolos e telhas como agregado de concreto para a construção de uma ponte, que até hoje subsiste.

Atualmente retoma-se a preocupação em definir o que fazer com toneladas de resíduos que são gerados por reformas e demolições ou mesmo por sobras e desperdícios de novas construções.

Dos países desenvolvidos nos chegam os melhores exemplos de reaproveitamento dos resíduos sólidos, apesar destes também enfrentarem, por ausência ou falha de fiscalização, problemas com entulho lançado na paisagem urbana, em aterros ou vias públicas. Nos Estados Unidos, por exemplo, existem fortes empresas que geram lucros enormes com a demolição de casas, transportando todo esse material para as usinas recicladoras onde são separados e montanhas de materiais estão prontos para serem vendidos como matéria-prima. Segundo PINTO (1995) "qualquer ação de reciclagem somente tem sentido se forem contabilizados os benefícios ambientais para a 
comunidade e as economias no transporte do material depositado irregularmente na malha urbana".

Embora ainda não existam estatísticas de todo o país, na média, o "entulho que sai dos canteiros de obras brasileiros é composto basicamente de 64\% de argamassa, 30\% de componentes de vedação (tijolo maciço, tijolo furado e blocos) e $6 \%$ de outros materiais como concreto, pedra, areia, metálicos e plásticos", TÉCHNE (1995). Esses valores não podem ser tomados como absolutos dada a grande heterogeneidade dos resíduos em todo o país e dos materiais que as constituem, porém estas estatísticas vêm revelando uma tendência nas características de composição dos materiais, à medida que estudos vão se desenvolvendo e aprimorando.

Observando-se estes dados, não fica muito difícil de entender que o resultado do entulho venha a ser um material basicamente de qualidade. "É necessário encontrar soluções para o problema dos resíduos, com formas práticas de reciclagem, na própria obra ou em usinas montadas para este fim. A construção civil é a única indústria capaz de absorver quase totalmente os resíduos que produz", AGOPYAN (1995).

\subsection{Algumas Usinas de Reciclagem do Brasil}

\subsubsection{Usina de Itatinga - SP}

A primeira usina recicladora do Hemisfério Sul foi a montada em São Paulo durante a gestão de Luiza Erundina na Prefeitura, em 1989. Com capacidade para reciclar até $700 \mathrm{~m}^{3}$ diários de resíduos, a usina de Itatinga, instalada no bairro de Santo Amaro, revertia o material produzido para a pavimentação de vias públicas. Após algum tempo desativada, onde passou por uma reformulação, atualmente a usina voltou a funcionar, porém com capacidade abaixo de seu potencial máximo.

Um exemplo bastante otimista e empreendedor foi que, na época, a Emurb Empresa Municipal de Urbanização realizou o projeto de uma fábrica de componentes acoplada à usina de Itatinga. As projeções indicavam que tais componentes feitos com material reciclado poderiam atingir até $70 \%$ de economia em relação aos comumentes encontrados no mercado. 
Apesar da interrupção dos trabalhos da usina de Itatinga, foi possível constatar na prática, o potencial da correta reciclagem de materiais de construção. "Em regime de plena utilização o custo do material produzido na usina recicladora chega a ser 20 a $30 \%$ do preço de mercado da pedra britada", GRANATO (1995).

Baseado na experiência de Itatinga, algumas aplicações mais adequadas para o resíduo reciclado que foram brevemente reproduzidas abaixo:

- Material para reforço de sub-base de ruas, avenidas e estradas;

- Agregados para construção, utilizados em cascalhamento, concreto e até mesmo em construção em geral;

- Blocos e material de argamassa: o processo de britagem produz material fino em grande quantidade e a um baixo custo;

- Aterro.

\subsubsection{Usina de Santo André - SP}

Santo André, município da Grande São Paulo, foi outra prefeitura que, na mesma época, avançou na direção de um projeto de uma usina para reciclagem diária de $350 \mathrm{~m}^{3}$ de resíduos, com produção simultânea de componentes de construção da ordem de 4 mil blocos de concreto por dia. Estudos realizados na ocasião, e nas condições específicas, apresentavam uma relação de um décimo (1/10) entre o custo de reciclagem e os gastos abolidos pela introdução desta prática.

O projeto desenvolvido por Paula Pinto apresentava a possibilidade de se gerar agregados a um custo $83 \%$ inferior aos preços médios dos materiais convencionais comerciais e também a viabilidade de se produzir blocos de concreto com preço $45 \%$ menor do que os componentes de qualidade existentes no mercado. Mesmo com esses números favoráveis, a usina não foi montada devido a problemas econômicos vividos pelo país naquele período. Somente mais tarde (1995), a prefeitura local retomou os estudos para tentar viabilizá-la, PINTO (1995). 


\subsubsection{Usina de São José dos Campos - SP}

Segundo artigo da revista Construção n. 2505, de fevereiro/96, "um bom exemplo do peso que a situação do entulho significa no dia-a-dia das cidades, encontra-se na cidade de São José dos Campos, município no interior paulista com 500 mil habitantes. Um diagnóstico realizado na cidade revelou que durante o ano de 1995 o entulho representou 64,76\% dos resíduos sólidos urbanos, compostos por blocos, argamassa dura, cerâmica, areia, pedra, concreto e minerais como estes. Os restantes 35\% do resíduo compunham-se por lixo doméstico, comercial, hospitalar e material de poda e varrição juntos". Com projeto da I\&T, a usina inaugurou suas instalações em abril de 1997, mas ainda apresenta produção pequena.

\subsubsection{Usina de Ribeirão Preto - SP}

No final de 1996 entrou em operação na cidade de Ribeirão Preto, uma estação de reciclagem de entulhos, com capacidade para processar $200 \mathrm{t} / \mathrm{dia}$. Pelo diagnóstico da I\&T, a cidade, com mais de 500 mil habitantes, produz cerca de 970 t/dia de entulho. O projeto incluiu estação de reciclagem, postos de recepção e banco de solos.

Atualmente, com produção diária abaixo da capacidade total, produz reciclados na forma de bica corrida. Os reciclados têm sido utilizados, em sua maior quantidade, na recuperação de vias públicas da periferia sem pavimentação asfáltica e, em menor proporção, na fabricação de blocos. A situação tem se tornado crítica por não haver áreas de descarte para o entulho nas regiões sul e leste da cidade.

Até então, todo o material era encaminhado para a zona norte, significando 11 mil viagens em 18 meses. A solução foi a indicação da implantação de 2 usinas, das quais apenas uma opera na região norte e que, sem computar o terreno, custou aproximadamente 130 mil reais. Foram também implantados postos de recepção pois, "sem tudo isso, o sistema ficaria ocioso", CONSTRUÇÃO (1996) ${ }^{1}$.

A Usina de Reciclagem de Ribeirão Preto constitui-se objeto de estudo desta pesquisa, por situar-se nas proximidades da cidade de São Carlos. Além disso,

\footnotetext{
${ }^{1}$ Revista Construção, n. 2505 fev./96
} 
a efetivação de sua implantação e funcionamento em tempo oportuno, novembro de 1996, constituiu-se fator fundamental e relevante para obtenção dos materiais estudados, a fim de que se pudesse, na prática, demonstrar a viabilidade e grande potencial de utilização do material reciclado. As Figuras 3.1 a 3.5 apresentam as dependências da usina e alguns detalhes do equipamento de britagem utilizado:

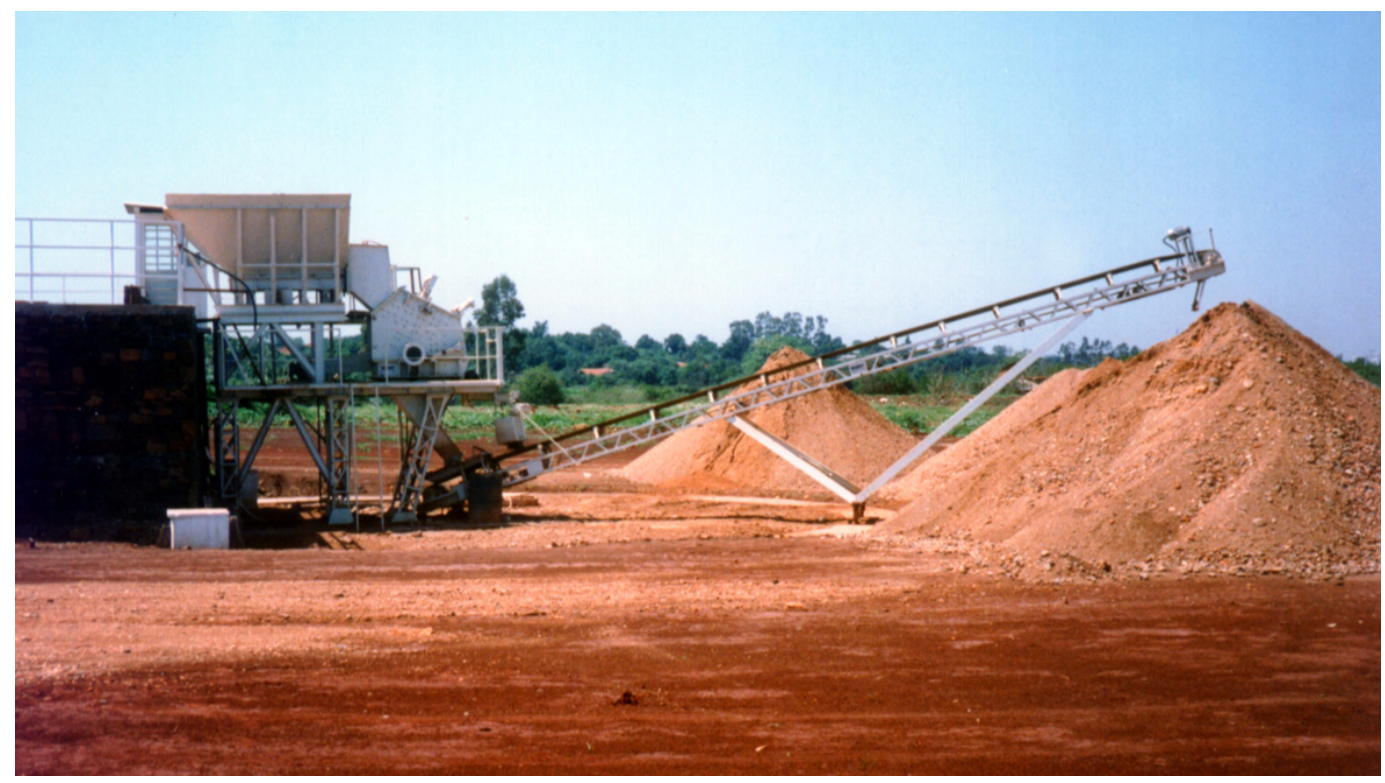

Figura 3.1 - Vista geral da Usina de Reciclagem de Ribeirão Preto

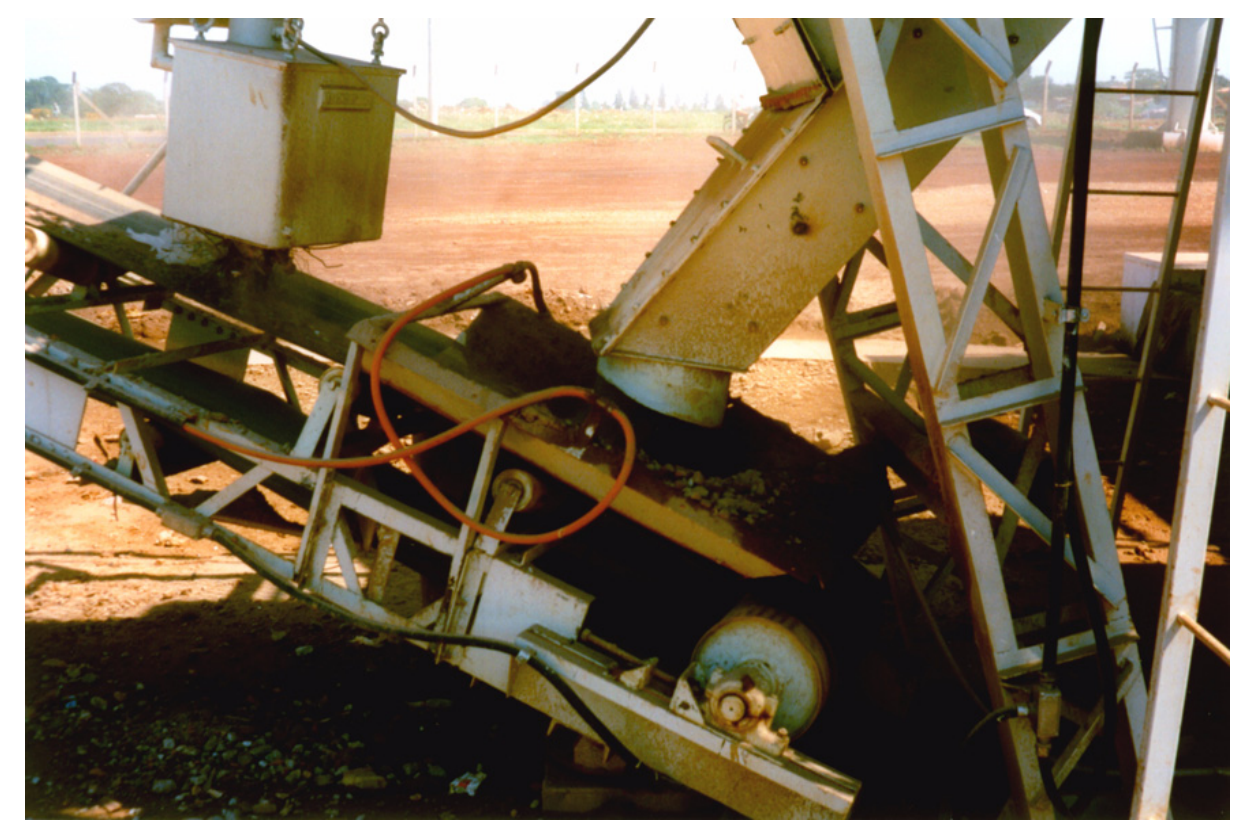

Figura 3.2 - Calha que alimenta o transportador de correia 


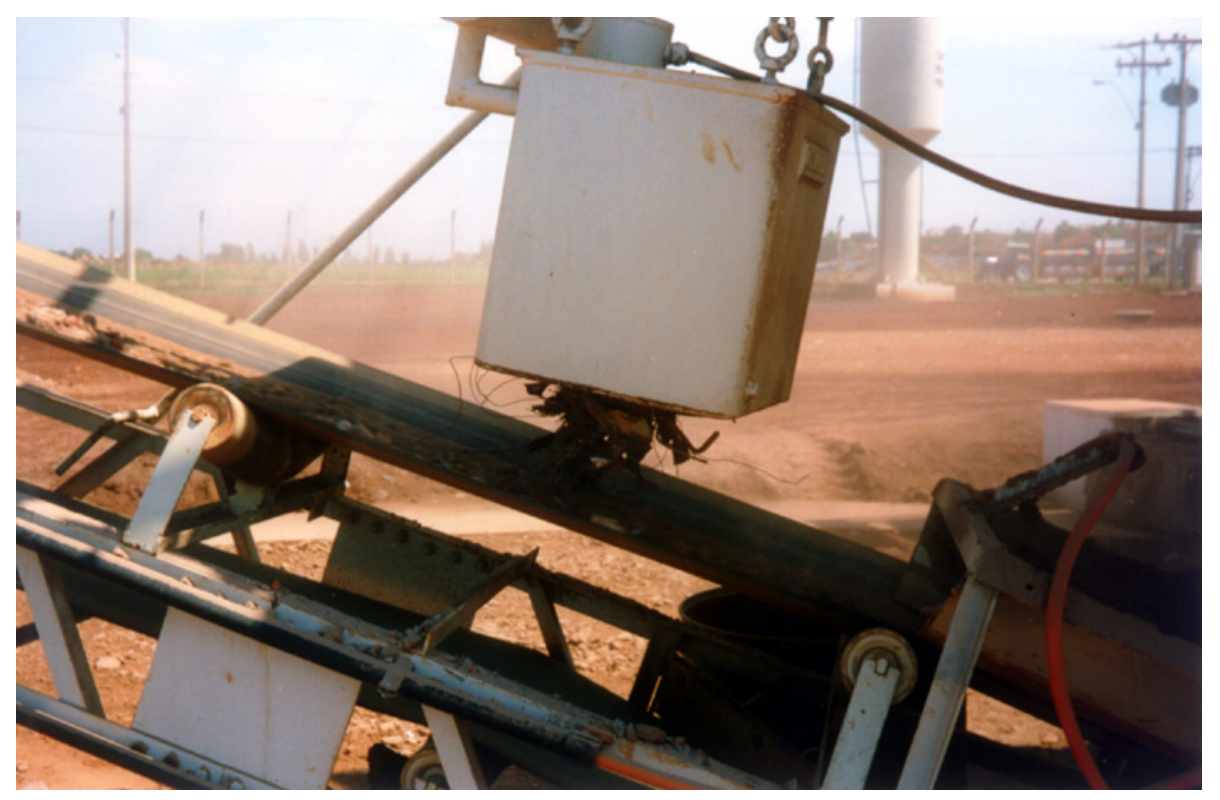

Figura 3.3 - Eletroímã para retirada de metais ferrosos

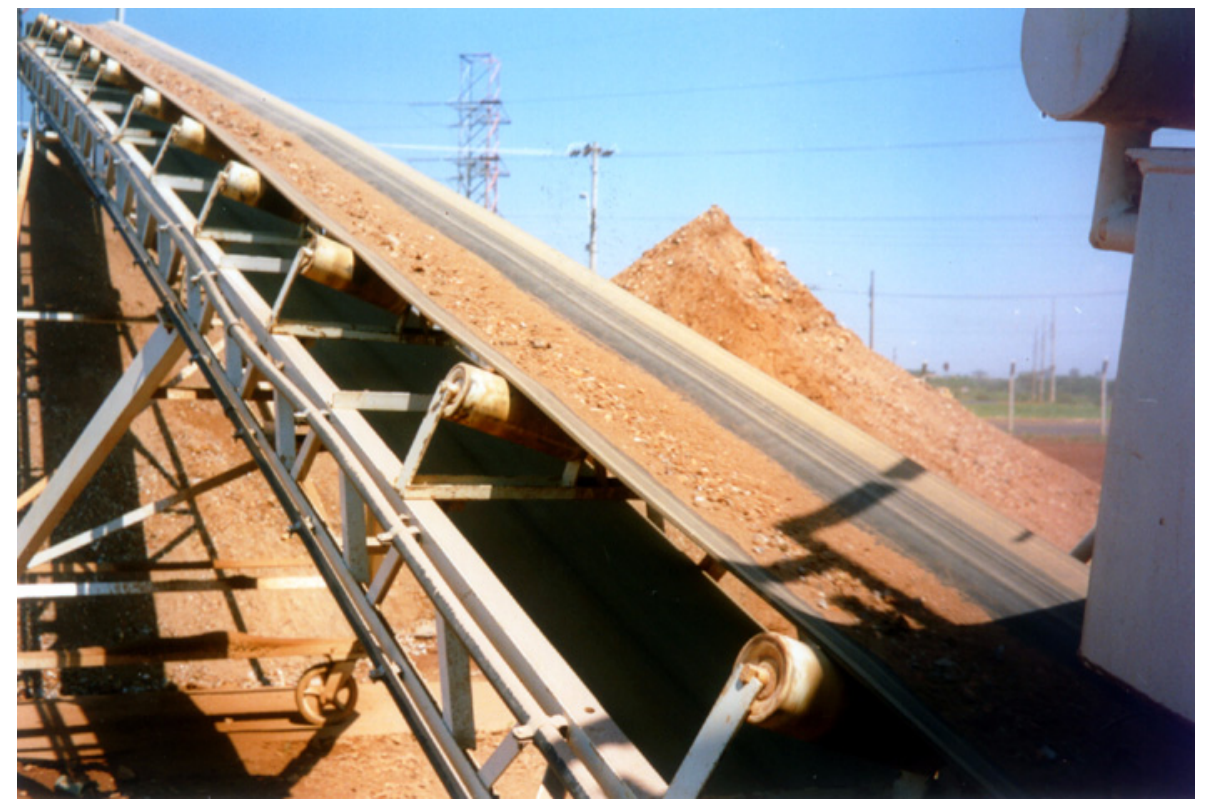

Figura 3.4 - Transportador de correia 


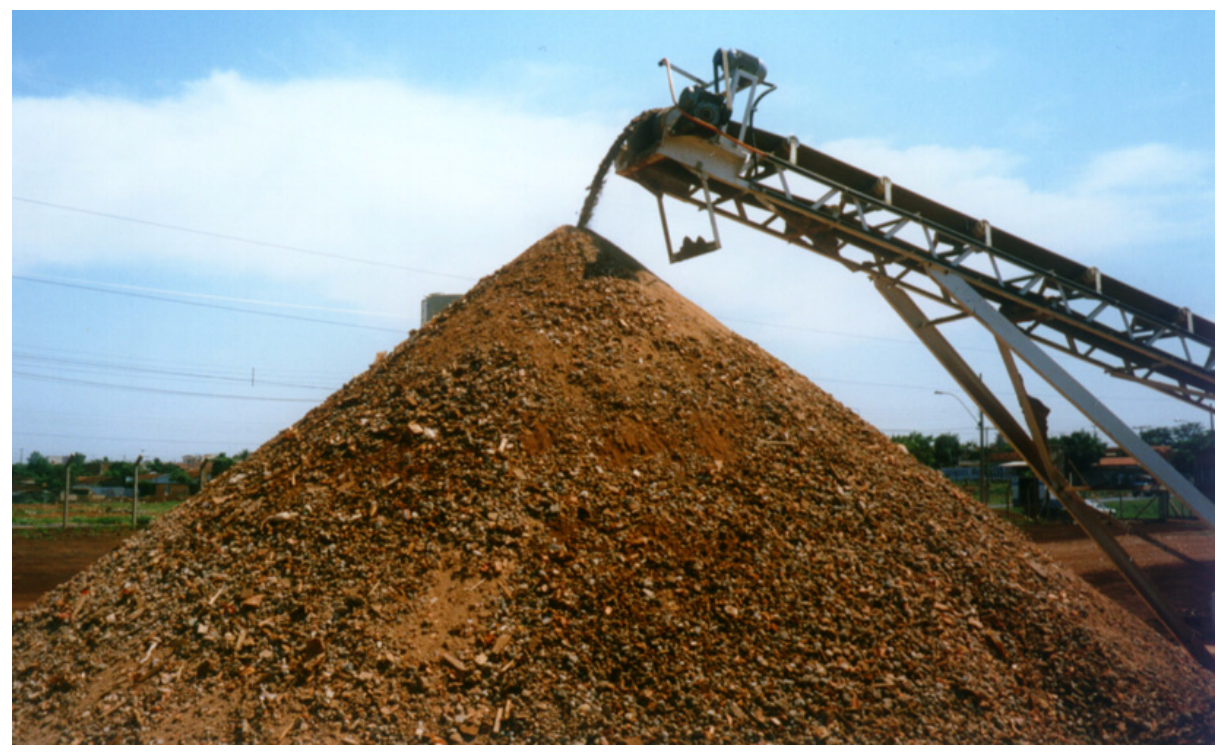

Figura 3.5 - Área de estocagem de material

\subsubsection{Usina de Belo Horizonte - MG}

Em Belo Horizonte - MG, a prefeitura está colocando em prática um programa de reciclagem de material de construção, desenvolvido pela I\&T Informações e Técnicas em Construção Civil, que apresenta um fator inovador por ter uma característica descentralizada. Foi possível alcançar bons resultados naquela cidade pela união da reciclagem com a captação ordenada de resíduos, buscando-se a potencialização de resultados, obtendo-se um material de construção barato e melhorando-se o ambiente urbano.

Em levantamento estatístico realizado pela I\&T em 1993 na cidade, constatouse uma produção de $2.000 \mathrm{~m}^{3}$ de resíduos por dia, sendo $1.250 \mathrm{~m}^{3}$ proveniente de desaterro e $750 \mathrm{~m}^{3}$ de entulho gerado nos processos de construção. O levantamento indicou a existência de 134 áreas de deposição clandestina, que resulta numa coleta de aproximadamente $425 \mathrm{~m}^{3}$ de material por dia. Economicamente falando, essa realidade traduz-se num gasto anual de mais de 1 milhão de dólares para a Superintendência de Limpeza Urbana da Cidade, o que significa dizer que são gastos 9,5 dólares por $\mathrm{m}^{3}$ para o gerenciamento destes resíduos incorretamente depositados na malha urbana, "valor que se aproxima também dos verificados em outras cidades", PINTO (1995).

Com um custo total de aproximadamente 100 mil dólares, o programa de Belo Horizonte foi previsto para ser implantado em várias etapas e integra uma 
política geral da prefeitura para o tratamento dos resíduos sólidos da cidade. Este valor de investimento é considerado razoável pela Superintendência de Limpeza Urbana de Belo Horizonte, já que são gastos cerca de 3 mil dólares por dia com o trabalho de coleta, transporte e deposição final desse material, TÉCHNE (1995).

Segundo o programa realizado pela I\&T, uma das fases mais importantes do estudo prevê, na região oeste de B.H., a instalação de uma rede de 4 estações de recepção de resíduos e nucleamento de coletores, montadas em áreas públicas de pequeno porte.

Com as quatro estações de reciclagem previstas e um amplo trabalho de fiscalização e educação ambiental, espera-se atingir um volume estimado de reciclagem de $8.800 \mathrm{t} /$ mês de resíduos, com produção de $5.500 \mathrm{~m}^{3}$ de agregados reciclados, podendo chegar até $80 \%$ na redução do custo da produção dos agregados. Os resíduos reciclados são usados para frentes de trabalho tais como sub-base ou tratamento primário de ruas, briquetes para calçadas, blocos para muração, agregados para "rip-rap"- usados em contenções de encostas ou canalizações, blocos para alvenaria de casas populares, ou também como em agregados para produção de tubos, guias, sarjetas e bocas-de-lobo, entre outros, TÉCHNE (1995).

\subsubsection{Prefeitura de Londrina - PR}

Outro exemplo localiza-se na região Sul do Brasil onde se encontra a usina de reciclagem da cidade de Londrina no estado do Paraná, a aproximadamente $600 \mathrm{~km}$ de São Paulo. A central fica estabelecida numa grande área afastada da cidade onde o entulho chega, através de caminhões e/ou caçambas que, na maioria das vezes, são alugadas pelos construtores.

Com um procedimento semelhante às demais usinas, todo o material que chega é depositado num local onde passa por uma seleção prévia para separar o rejeito do que será moído, e então esta fração é levada para o "canteiro", assim chamado naquela região. A grande diferença entre esta usina e as demais é que aqui, primeiramente o entulho passa por uma moagem "grossa", num britador do tipo de mandíbulas, em que a principal função é diminuir o tamanho das peças de alvenarias e concretos recebidos.

Através de esteiras, o material é então levado para o $2^{\circ}$ equipamento que faz o rebritamento por meio de um moinho de martelos. Os 2 britadores estão 
dispostos em série, um em seguida do outro, conforme mostra a Figura 3.6, que "produzem" o agregado todo misturado, do tipo bica corrida, seguindo-se a partir daí o "peneiramento" de todo este "produto".

Este "peneiramento" ocorre da seguinte maneira: o material cai num cilindro giratório (ou peneira rotativa) que possui 2 partes; a $1^{\text {a }}$ com orifícios menores e a $2^{\mathrm{a}}$ com orifícios um pouco maiores. Na primeira parte passam os materiais classificados como areia e pedrisco; na segunda, os materiais denominados brita 1. Este equipamento pode ser visto na Figura 3.7. Ainda no final do cilindro, que possui uma parte aberta, acabam por sair as britas maiores. Por fim, esta última parcela mais graúda do material é colocada novamente nos britadores de martelos pois, por hora, o que interessa naquela usina é a produção de areias e pedriscos.

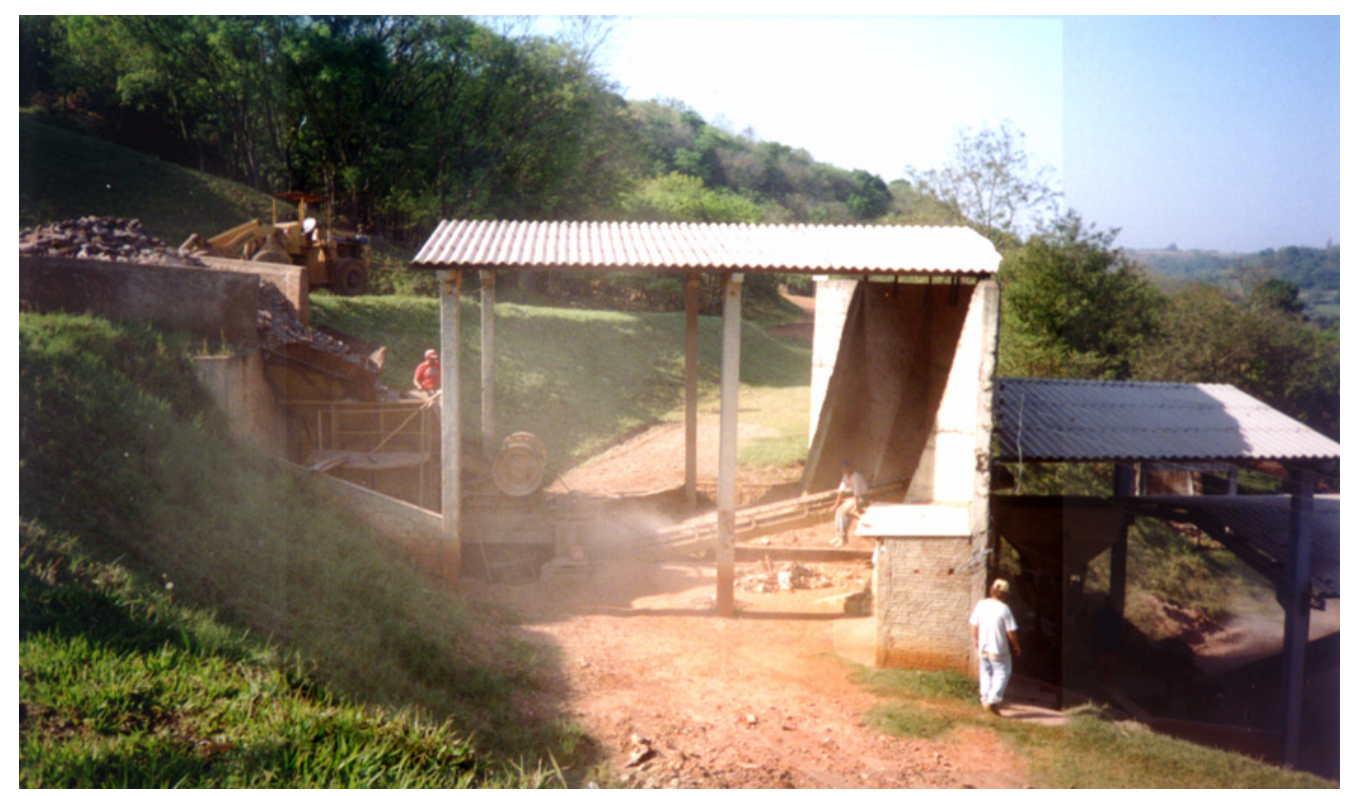

Figura 3.6 - Vista geral da Usina de Reciclagem de Londrina - PR com 2 britadores dispostos em série 


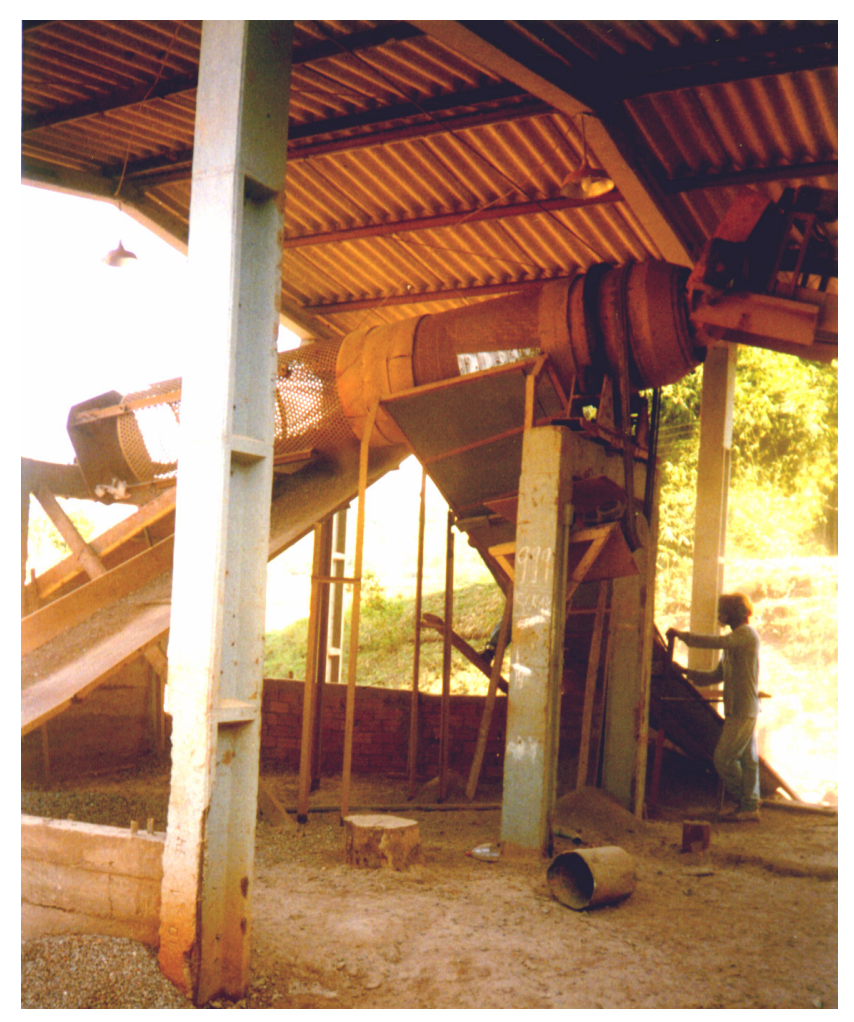

Figura 3.7 - Peneiras rotativas

No próprio local de fabricação, a areia e o pedrisco são utilizados na fabricação de blocos de concreto para vedação, e briquetes sextavados utilizados para calçamento de pisos de praças. Existe também o interesse na utilização do agregado graúdo de diâmetro maior em peças de concreto tais como lajes, pilaretes, etc, porém não se encontrando ainda embasamento técnico devido a limitações locais e, por estar enfrentando alguns problemas de ordem política, não se tem muito interesse em dar continuidade ao projeto. Este fato demonstra a grande importância da presente pesquisa com a finalidade de fornecer uma aplicação prática para os materiais reciclados.

A usina tem uma produção estimada de 8 a $10 \mathrm{t} / \mathrm{h}$ de material reciclado dos quais $60 \%$ são areia, $8 \%$ pedriscos e $30 \%$ a $40 \%$ outras britas. Os blocos produzidos na usina estão sendo utilizados em construções habitacionais populares e em favelas.

Alguns dados dos materiais reciclados produzidos nesta usina serão comparados, no capítulo 4, com os obtidos neste trabalho. 


\subsection{Equipamentos}

\subsubsection{Equipamentos de Grande Porte}

Nos últimos anos, várias empresas como a Hazemag, Krupp, Kleeman Reiner e a Nordberg, entre outras, empresas multinacionais especializadas em máquinas de britagem, tradicionalmente utilizadas em pedreiras, têm destinado uma parcela importante de sua produção para usinas de reciclagem em várias partes do mundo. Estes equipamentos são adequados para britagem de materiais com dimensão granulométrica grande, e com o material resultante, é possível fazer uma série de trabalhos dos quais, os principais até o momento, são de pavimentação ou de confecção de blocos para alvenaria. "A montagem de uma usina recicladora de entulho tornou-se nos últimos anos parte de um processo de mudança de mentalidade de preservação das fontes naturais de matérias-primas", GRANATO (1995).

Existem meios para que a indústria da construção civil possa absorver praticamente todo o resíduo por ela gerado. Britadores são os equipamentos do tipo que são usados em pedreiras, que aparecem quando se quer transformar uma peça feita em concreto; por exemplo parte de uma viga, de um pilar, pedaços de laje, ou mesmo uma caixa d'água de concreto que foi demolida; em partículas menores como pedra, pedrisco, areia, etc. Um equipamento de britagem de grande porte, basicamente, subdivide-se nas seguintes partes:

- alimentador vibratório - recebe o entulho que é despejado pela pá carregadeira;

- britador propriamente dito - pode ser de impacto ( caso de $\mathrm{BH}$ ), onde cai o entulho e possui capacidade que pode variar de 20 até mais de $100 \mathrm{~m}^{3}$ / hora de produção; e também de mandíbulas ( como em outros casos );

- calha vibratória - equipamento que capta o produto do britador e alimenta o transportador de correia;

- transportador de correia - responsável pela condução do material para a área de estoque;

- nebulizador - protege a saída dos agregados, evitando a formação de nuvens de poeira; 
- eletroímã - peça importante do conjunto, instalada acima do transportador, com a função de retirar todos os metais ferrosos, para não contaminar os agregados.

\subsubsection{Equipamentos de Pequeno Porte}

Outras alternativas que vêm possibilitando resultados significativos de economia e de gerenciamento é a reutilização do resíduo na própria obra onde ele é gerado, através de um equipamento simples, de médio porte, com função dupla de moer os agregados e "fabricar" argamassas, fabricado por empresas como a ANVI e a Mecânica Alfa. Com ele é possível produzir argamassas na proporção 1 : 11 de cimento e agregado, além de se economizar com o transporte do bota-fora, segundo o fabricante, (ANVI).

Algumas empresas fizeram um levantamento de desempenho para esse tipo de argamassa. Alguns estudos demonstraram que o produto feito com entulho chega a atingir resistência cerca de 3 vezes superior à resistência da argamassa tradicional. Este fato deve-se à recuperação das características originais destes materiais que viraram entulho, além da geração da pozolana, que é proveniente da moagem de blocos cerâmicos, NATENZON (ANVI) ${ }^{2}$.

LEVY (1997), utilizando este tipo de equipamento de pequeno porte (ANVI), avaliou o desempenho de argamassas produzidas, em princípio, para revestimento através da moagem de entulho de construção civil de 4 obras da capital de São Paulo. Os resultados obtidos demonstraram a viabilidade técnica de se empregar materiais cerâmicos finamente moídos, conferindo às argamassas um certo incremento nas propriedades mecânicas, em razão do potencial aglomerante desenvolvido pela atividade pozolânica, e pelo efeito "filler" apresentado pelos materiais cerâmicos.

Nesse estudo constatou-se ainda que as argamassas produzidas podem conferir uma economia, em média, de $30 \%$ no consumo de cimento, comparadas às argamassas convencionais.

${ }^{2}$ Revista TÉCHNE 1995 


\subsection{Questão de Gerenciamento}

O gerenciamento do problema do entulho em grandes cidades apresenta um número de dificuldades proporcional, na medida em que crescem os volumes gerados e , ao mesmo tempo, diminuem as áreas para disposição, ou então, estas áreas afastam-se dos centros urbanos. Estima-se que o custo desta atividade seja da ordem de 4 vezes mais que o custo da própria reciclagem, CONSTRUÇÃO (1995).

Estudos realizados pela Nortec, empresa representante de equipamentos de grande porte no Brasil, indicam que a reciclagem do entulho em usinas com equipamentos desta natureza, torna-se viável toda vez que for gerado em quantidades razoáveis, comportando plantas de $30 \mathrm{t} / \mathrm{h}$ a $500 \mathrm{t} / \mathrm{h}$. Entretanto, segundo levantamentos realizados pela I\&T, o mais importante é adequar o porte do conjunto de equipamentos à necessidade do município ou do canteiro de obras, que podem até atingir menores escalas de produção e consequentemente configurações mais simples como por exemplo de $20 \mathrm{t} / \mathrm{h}$. "É fundamental salientar que não basta a simples transposição dos equipamentos de britagem para o ambiente urbano, é necessário que a sua instalação seja rodeada de novos cuidados que vão permitir ao maquinário uma adequação para essa finalidade", PINTO (1995). Esses cuidados visam principalmente a diminuição da geração de ruídos e de material particulado.

\subsection{Algumas Referências de Aplicações de Material Reciclado na Construção Civil}

\subsubsection{Leitos de Vias Públicas e Estradas}

Com o objetivo de apresentar um programa de reciclagem de entulho de construção cilvil para fins de pavimentação na cidade de São Paulo, BODI (1995) et all realizaram estudos de laboratório e análise dos pavimentos construídos com esses materiais. Duas frentes foram estudadas quanto ao reaproveitamento do entulho de construção civil reciclado: fabricação de prémoldados de concreto e utilização como material para pavimentação.

Após uma breve explanação sobre a problemática do entulho em São Paulo, alguns fatores orientaram os autores na busca de soluções, quais sejam: 
Em São Paulo, são várias as vias urbanas não pavimentadas onde a população utilizou entulho de construção civil como revestimento primário do sub-leito, visando diminuir a lama em tempo chuvoso e a poeira em tempo de estiagem. notou-se que houve uma estabilização do solo e do sub-leito, melhorando suas condições de suporte, com a incidência das chuvas e aliada à compactação pelo próprio tráfego local.

Desempenho altamente satisfatório da rua Gervásio da Costa, executada como entulho de construção civil na camada de reforço do sub-leito, com acompanhamento executivo e de desempenho pelo IPT - Instituto de Pesquisas Tecnológicas.

Foram realizados ensaios de CBR (Califórnia Bearning Ratio) e Mini-CBR para se determinar os parâmetros geotécnicos do solo, e também ensaios triaxiais em vários tipos de entulho, chegando a capacidade de suporte e módulos elásticos amplamente satisfatório.

Quando comparados os valores de CBR entre misturas de solo/agregado natural com solo/entulho britado, constatou-se que nesta última, os valores de CBR equivalentes eram atingidos por menores proporções de mistura. Outro bastante relevante foi a constatação de que não ocorreram grandes variações da massa aparente seca das misturas solo/entulho britado.

Os estudos apontam o entulho de construção civil como sendo um excelente material para compor bases granulares e reforço de sub-leito, misturado ou não com o solo.

\subsubsection{Concretos para Construção Civil}

Em trabalhos desenvolvidos por YANNAS (1977), foram avaliadas e comparadas as propriedades mecânicas de um concreto convencional com um concreto contendo, no lugar do agregado graúdo comum, pedaços de concretos de resíduos de demolição. Neste caso, o concreto reciclado apresenta um comportamento mecânico mais parecido com o concreto convencional quando contém agregados reciclados com maior porcentagem de graúdos do que de finos. Neste trabalho foram substituídos todos os agregados graúdos da mistura por pedaços de resíduos de concreto e estudado os efeitos desta substituição quanto a resistência à compressão, módulo de elasticidade e consistência. 
A trabalhabilidade dos 2 concretos foi similar, porém o concreto reciclado apresentou uma resistência à compressão $76 \%$ do concreto convencional e módulo de elasticidade cerca de $60 \%$ a $100 \%$ do mesmo.

YANNAS cita que descobertas de BUCK em 1973 revelam que concreto reciclado pode ser melhor aproveitado como substituto de agregado graúdo apenas, e sugere a utilização de concreto reciclado em regiões onde a deposição torna-se um problema ou onde jazidas de agregados naturais não são acessíveis. "Trabalho considerável, entretanto, ainda precisa ser feito antes que o "novo" produto possa ser entendido suficientemente para ser usado com segurança por engenheiros e construtores", diz ela.

Estudos mostram que o concreto poderia ser produzido inteiramente a partir de produtos residuais como agregados de concreto reciclado e cinza volante, sem a presença de Cimento Portland na mistura. Devido a reação pozolânica entre a cinza volante e o hidróxido de cálcio da pasta de cimento existente no concreto velho, o concreto reciclado ganha resistência muito lentamente.

YODA (1988) relatou o desenvolvimento, no Japão, de um cimento reciclado que era produzido contendo concretos triturados com altos teores de cimento. Entretanto, constatou-se que a resistência à compressão de concretos feitos com tais cimentos reciclados era aproximadamente a metade da resistência à compressão de concretos feitos com Cimento Portland Comum, para mesmas condições de cura e fator água/cimento.

Na França, após uma breve discussão sobre os problemas da demolição de edifícios e locais de deposição para estes rejeitos, BERNIER (1978) apresentou uma proposta para a solução do problema, por eles denominada de "Bibeton", que consiste em se partir de um concreto inicial perfeitamente conhecido do ponto de vista de sua composição e propriedades mecânicas (concreto primário) e, a partir deste, confeccionar um concreto reciclado, que foi dividido em 2 categorias:

Bibeton I - utiliza todas as faixas de granulometria dos rejeitos britados, como agregado para concreto.

Bibeton II - utiliza apenas agregados graúdos reciclados na confecção de concretos reciclados.

Suas propriedades mecânicas foram comparadas e resultados surpreendentes foram obtidos com o Bibeton II, que praticamente manteve as mesmas características do concreto primário, em relação a tensão-deformação. Deve-se notar que o concreto contendo apenas agregados reciclados graúdos é que obteve melhores resultados, fato que vem de encontro ao proposto por este trabalho. 
HANSEN e BOEGH (1985) fizeram uma investigação sistemática do módulo de elasticidade e da retração de concretos de agregados reciclados feitos de agregados graúdos reciclados e areia natural, como função dos mesmos parâmetros dos concretos originais dos quais os agregados foram derivados. Os autores citam que os números alcançados vieram confirmar resultados relatados por Mukai (1979), e Wesch e Shulz (1982), de 15\% a 30\% mais baixos módulo de elasticidade para o concreto reciclado, e $40 \%$ a $60 \%$ mais altos índices de retração em relação ao concreto original. Salientou-se também que, quando concretos reciclados contêm grande quantidade de argamassa velha reciclada, a retração desses concretos pode ser muitas vezes maior do que aquela dos concretos convencionais (70\% maior em alguns casos) e o módulo de elasticidade pode atingir valores acima de 50\% mais baixos do que aqueles de controle.

Um estudo bastante recente foi o apresentado em outubro de 1993 , no $3^{\underline{o}}$ Simpósio Internacional Rilem em Demolição e Reuso de Concretos e Argamassas, o qual tornou-se uma Recomendação RILEM para utilização de agregados graúdos reciclados para concreto com $\phi \geq 4,0 \mathrm{~mm}$. Estas especificações classificam em diferentes categorias os agregados graúdos reciclados e indicam o campo de aplicação para concretos contendo esse material. Os 3 tipos de agregados classificados nesta especificação estão descritos a seguir:

Tipo I : agregados reciclados que se originam principalmente de pedaços de alvenaria;

Tipo II : agregados reciclados que se originam principalmente de pedaços de concreto;

Tipo III : agregados que compõem-se de uma mistura de agregados reciclados e naturais.

É recomendado, nestas especificações que, na ausência de dados experimentais mais acurados, para uma estimativa aproximada, as características destes materiais podem ser obtidas pela multiplicação dos seguintes coeficientes, transcritos na Tabela 3.1:

Tabela 3.1 - Coeficientes de relação

\begin{tabular}{|c|c|c|c|}
\hline Valores de Projeto & Tipo I & Tipo II & Tipo III \\
\hline resistência à tração & 1 & 1 & 1 \\
\hline módulo de elasticidade & 0,65 & 0,8 & 1 \\
\hline coef. de fluência & 1 & 1 & 1 \\
\hline retração & 2 & 1,5 & 1 \\
\hline
\end{tabular}


Os agregados classificados como Tipo I, e Tipo III com alguma variante, apresentam-se semelhantes aos agregados utilizados neste estudo, e seus coeficientes, com maior interesse para resistência à tração, serão objeto de análise e comentários no capítulo 5.

Além dessas proposições, é feita uma série de advertências quanto ao uso, em concretos, de agregados finos reciclados, devido seus aspectos limitantes e desconhecidos. Sugere-se então, a realização de estudos mais aprofundados para a utilização desses materiais.

ZORDAN (1997) realizou um estudo com o objetivo de avaliar o material proveniente da reciclagem de entulho para confecção de concretos. Diferentes traços e relações água/cimento foram utilizados. Uma de suas avaliações demonstrou que, dentre as proporções que estavam sendo comparadas, para as que continham menor consumo de cimento, a resistência à compressão dos concretos com reciclados aproximou-se daquelas obtidas para concretos de referência.

Entretanto, uma característica que deve ser salientada neste estudo é que o autor não realiza a separação granulométrica das graduações de agregados a serem utilizados nos concretos, tratando o entulho reciclado como um todo, ou seja, contendo agregados graúdos e miúdos em sua composição.

Esta característica apresenta-se bastante diferenciada do presente trabalho, pois avalia-se aqui, a presença dos agregados reciclados graúdos apenas, para confecção de concretos. Mesmo assim, o autor faz uma avaliação qualitativa e granulométrica do entulho reciclado, como um todo, o que será objeto de comparações e comentários oportunamente.

Usinas de concreto, também chamadas centrais de concreto, podem ser tomadas como exemplo de geradores de resíduos sólidos (entulho), dado à quantidade de concreto "retornável" que ela está sujeita. O concreto que retorna a uma central de concreto pode chegar a 3\% da produção diária. Só para se ter uma idéia, análises preliminares em uma usina de concreto típica, com retorno médio de $10 \mathrm{~m}^{3}$ da produção diária de concreto, demonstraram que a perda potencial na quantidade de agregados pode totalizar $2.520 \mathrm{~m}^{3}$ por ano, CONCRETE INTERNATIONAL (1997).

Pesquisas citadas na literatura por HANSEN (1992) \& RASHWAN (1995) indicam que o concreto reciclado proveniente de um processo de trituração (britagem) pode oferecer certos benefícios incluindo altos valores de isolação, resistência ao fogo e baixas densidades, enquanto mantém o nível de resistência à compressão equivalente ao obtido pelo concreto feito com agregado natural. Entretanto, algumas desvantagens também citadas na literatura incluem retração por secagem e menor durabilidade do concreto reciclado. 
Em HANSEN (1992), encontra-se que Rashwam e Rizk (1997) realizaram um estudo analisando as propriedades do concreto confeccionado com agregados reciclados provenientes de retorno e lavagem de equipamentos de usinas de concreto, e suas influências relativas ao período de cura, antes de passar pela trituração e, ao período de estocagem anterior ao uso.

Era de se esperar que as partículas de cimento não hidratadas poderiam contribuir para o volume de cimento contido no concreto reciclado. A hidratação do cimento é um processo que depende do tempo e portanto, deveria haver uma duração ótima, após a qual o concreto está pronto para britagem, e ao mesmo tempo conter a mais alta porcentagem possível de partículas de cimento não hidratadas.

Também haveria uma duração ótima de estocagem do material reciclado anterior ao qual, o máximo de benefício poderia ser ganho a partir da contribuição das partículas de cimento não hidratadas. Portanto as 2 fases do experimento foram designadas para investigar os efeitos do tempo nas propriedades dos produtos reciclados e eventualmente determinar o período de tal duração.

Com a finalidade de maximizar os benefícios obtidos pelo processo de reciclagem e minimizar problemas associados ao uso dos materiais reciclados, torna-se essencial entender mais profundamente as propriedades de tais materiais. A seguir, no capítulo 4, são estudadas as características dos materiais provenientes da usina de reciclagem de Ribeirão Preto (estudo de caso) após passarem pelo processo de britagem. Avaliação de resistência e algumas comparações com materiais de outras usinas também constituem-se objeto deste capítulo. 


\section{CARACTERÍSTICAS DOS MATERIAIS NATURAIS E RECICLADOS UTILIZADOS NA PESQUISA}

\subsection{Introdução}

Para estudar os efeitos do entulho reciclado como agregado graúdo para concreto, uma série de ensaios preliminares foram realizados no material coletado na usina de reciclagem e nos materiais naturais, e em corpos de prova moldados com concretos confeccionados com estes materiais.

Baseado na produção da usina de reciclagem de Ribeirão Preto, dois tipos de entulho foram identificados: $\mathrm{O}$ entulho tipo $\mathrm{A}$, contendo em sua composição materiais mais nobres como pedaços de concreto, argamassas, blocos de concreto, tijolos e materiais cerâmicos; e o entulho tipo B, contendo grande porcentagem de terra, poda de árvores e outros materiais não minerais misturadas na sua composição. Os estudos aqui apresentados referem-se apenas ao processamento do entulho tipo A para obtenção do agregado reciclado. A Figura 4.1 mostra uma pilha de entulho tipo A, proveniente da usina de Ribeirão Preto - SP. 


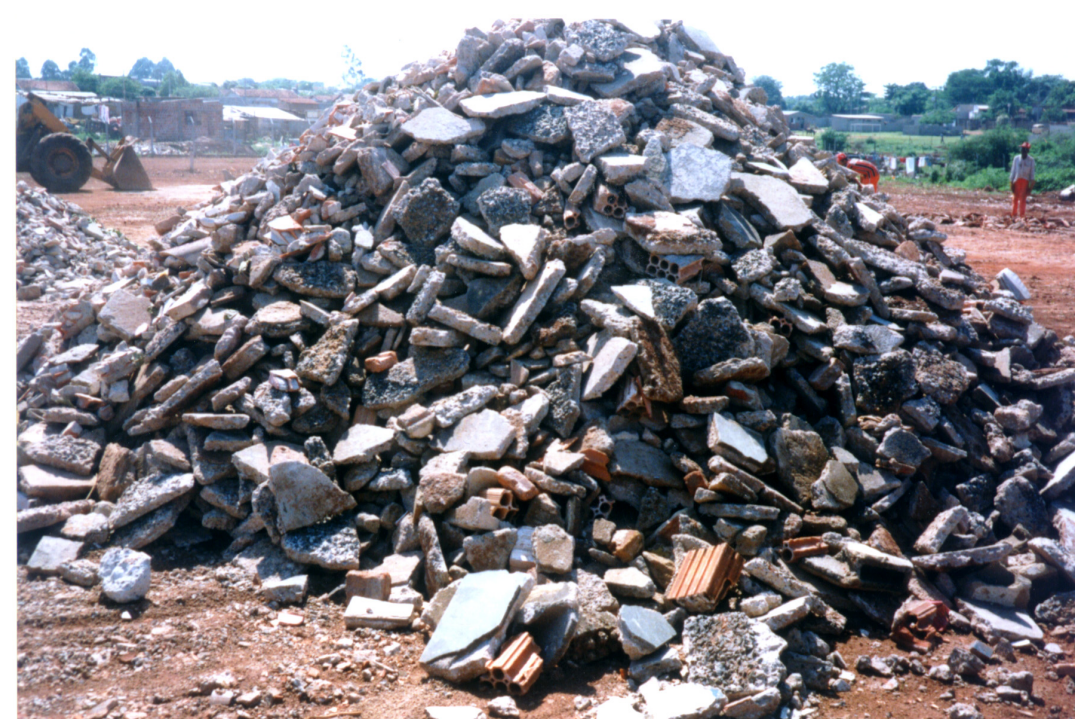

Figura 4.1: Pilha de entulho a ser britado

Após passar por um processo de britagem, num equipamento de grande porte, como o apresentado no capítulo 3, forma-se então uma pilha de material, nas mais diversas granulometrias, os quais estão potencialmente prontos para serem utilizados. Figura 4.2.

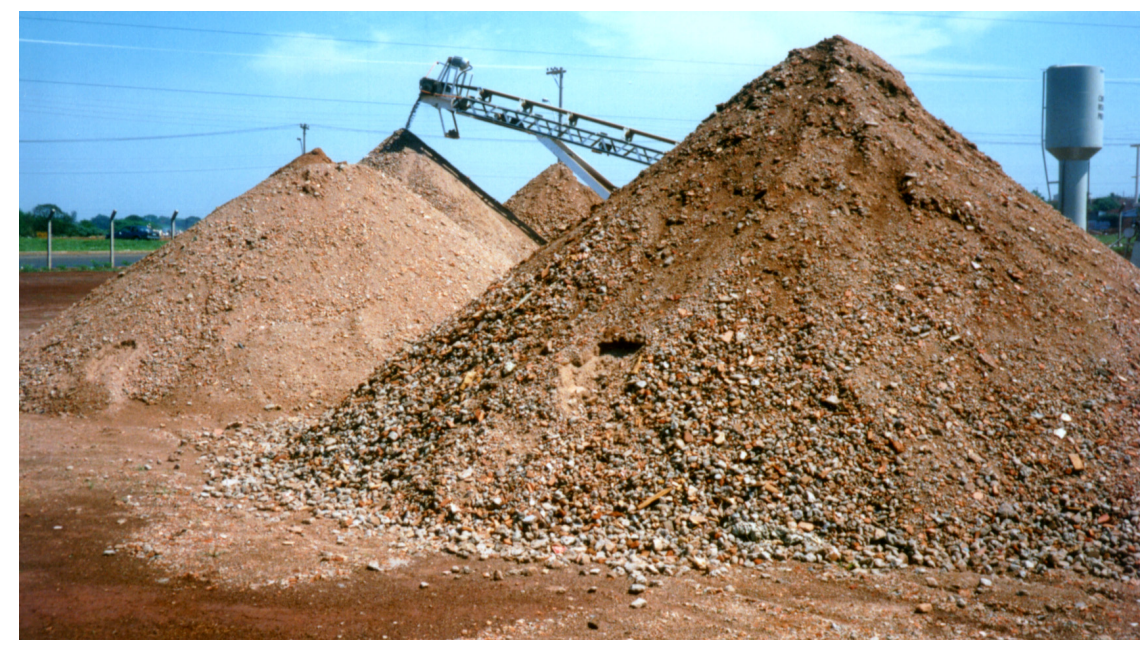

Figura 4.2: Pilha de entulho após processo de britagem

Um dos objetivos básicos da pesquisa consiste na confecção de concreto utilizando-se agregado graúdo reciclado proveniente da reciclagem de entulho. Sendo assim, tornou-se necessária a identificação da presença destes agregados graúdos, contidos na pilha de entulho reciclado, e quais as suas proporções. A priori, foram escolhidos os agregados compreendidos nas graduações normatizadas "brita 0" e "brita 1" por serem estes os mais utilizados em concretos para obras comuns de pequeno e médio portes. 
Sendo assim, duas etapas distintas foram executadas para avaliação dos materiais:

- Estudos Preliminares

- Estudos de Dosagem e Verificação de Resistência

\subsection{Estudos Preliminares}

Nesta etapa fez-se um estudo prévio para se ter uma idéia de como seria o comportamento do material reciclado e sua viabilidade na continuação da pesquisa, utilizando-se metodologia que abrangeu o seguinte:

- Coleta de amostras de entulho reciclado

- Caracterização granulométrica do reciclado

- Caracterização qualitativa do reciclado

\subsubsection{Coleta de Amostras do Entulho Reciclado}

Logo após o início das atividades da estação de reciclagem de Ribeirão Preto, uma amostra foi coletada, sem qualquer metodologia, diretamente nas pilhas de material já processado. Utilizando-se uma pá comum, recolheu-se amostras de entulho reciclado, em sacos plásticos, que foram transportados para o Laboratório de Estruturas da E.E.S.C.-USP. A amostra foi então reduzida para determinação da composição granulométrica e da natureza da composição da fração graúda do material ( $\mathrm{D}_{\text {máx }}>4,8 \mathrm{~mm}$ ).

O método utilizado para se obter uma amostra do campo que seja representativa para o laboratório foi o apresentado pela NBR 9941 "Redução de Amostra de Campo de Agregados para Ensaio de Laboratório", que apresenta o processo de quarteamento onde a amostra de campo é espalhada na forma circular e dividida em 4 (quatro) partes, sendo duas partes, diametralmente opostas, desprezadas. Com as outras duas, mistura-se novamente e repete-se o processo, até se obter a amostra para os ensaios. 


\subsubsection{Caracterização Granulométrica do Material Reciclado}

A caracterização granulométrica do resíduo foi realizada segundo prescrição da NBR 7217/87 “Agregado - Determinação da Composição Granulométrica”, que se constitui num processo de peneiramento, utilizando-se peneiras com aberturas de malhas pré-determinadas, denominadas série normal e série intermediária, compondo-se das seguintes peneiras estabelecidas pela norma, mostradas na Tabela 4.1:

Tabela 4.1 - Abertura das peneiras (NBR 7217/87)

\begin{tabular}{c|c}
\hline Série Normal & Série Intermediária \\
\hline $76 \mathrm{~mm}$ & --- \\
\hline--- & $64 \mathrm{~mm}$ \\
\hline--- & $50 \mathrm{~mm}$ \\
\hline $38 \mathrm{~mm}$ & $32 \mathrm{~mm}$ \\
\hline--- & $25 \mathrm{~mm}$ \\
\hline--- & --- \\
\hline $19 \mathrm{~mm}$ & $12,5 \mathrm{~mm}$ \\
\hline--- & --- \\
\hline $9,5 \mathrm{~mm}$ & $6,3 \mathrm{~mm}$ \\
\hline--- & --- \\
\hline $4,8 \mathrm{~mm}$ & --- \\
\hline $2,4 \mathrm{~mm}$ & --- \\
\hline $1,2 \mathrm{~mm}$ & --- \\
\hline $0,6 \mathrm{~mm}$ & --- \\
\hline $0,3 \mathrm{~mm}$ & --- \\
\hline $0,15 \mathrm{~mm}$ &
\end{tabular}

As faixas estabelecidas pela NBR 7211/83 "Agregados para Concreto" para agregados graúdos, correspondem às peneiras com abertura de malhas superior a $4,8 \mathrm{~mm}$.

Os intervalos entre as peneiras de $19,0 \mathrm{~mm}$ a $9,5 \mathrm{~mm}$, e entre $9,5 \mathrm{~mm}$ e 4,8 $\mathrm{mm}$, correspondem à graduação "brita 1" e "brita 0 " respectivamente. A Tabela 4.2 mostra a divisão, por faixa granulométrica, que foi utilizada:

Tabela 4.2 - Faixas granulométricas (Classificação Comercial)

\begin{tabular}{c|c|c|c|c}
\hline $38<\mathrm{D}<76 \mathrm{~mm}$ & $19<\mathrm{D}<38 \mathrm{~mm}$ & $9,5<\mathrm{D}<19 \mathrm{~mm}$ & $4,8<\mathrm{D}<9,5 \mathrm{~mm}$ & $\begin{array}{c}\mathrm{D}<4,8 \mathrm{~m} \\
\mathrm{~m}\end{array}$ \\
\hline brita 3 & brita 2 & brita 1 & brita 0 & $\begin{array}{c}\text { agregado } \\
\text { miúdo }\end{array}$ \\
\hline
\end{tabular}


Os primeiros resultados estão mostrados no gráfico da Figura 4.3.

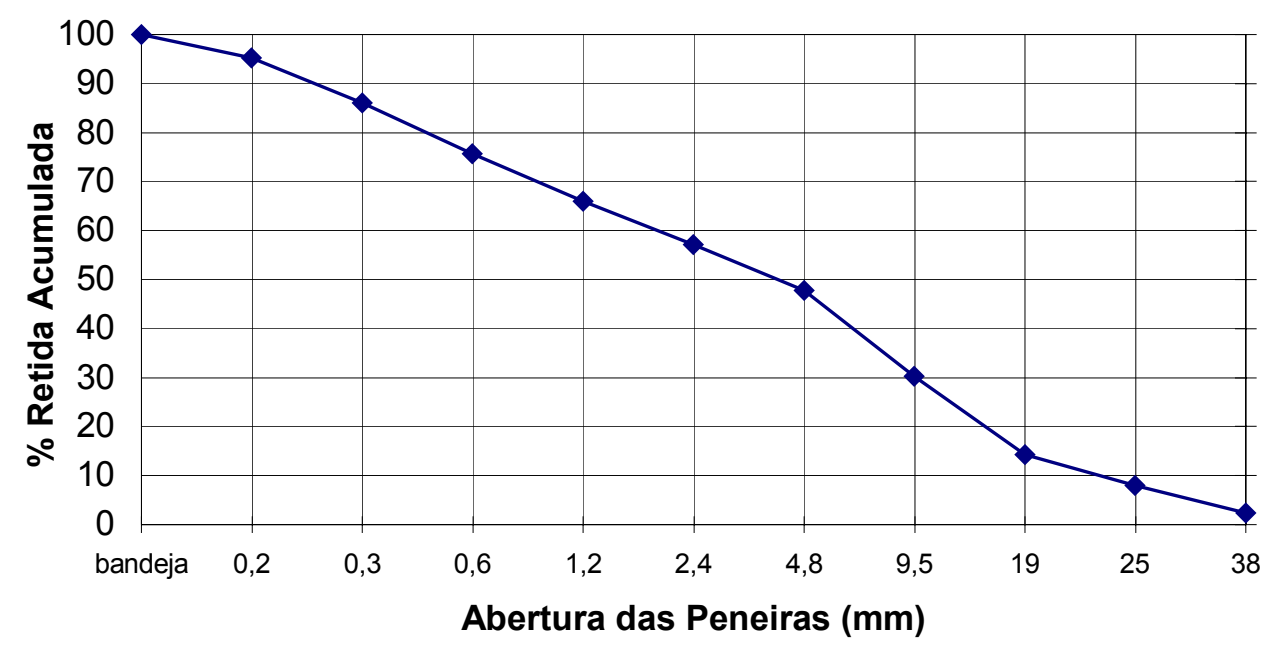

\section{Figura 4.3 - Curva granulométrica da amostra de entulho coletada em nov/96}

Os ensaios mostraram que $52 \%$ da amostra recolhida correspondiam à faixa dos agregados miúdos, ou seja, com diâmetro menor que $4,8 \mathrm{~mm}$ e que, do restante, $71 \%$ correspondia à faixa granulométrica enquadrada na pesquisa, isto é, graduação "brita 0" e "brita 1" da NBR 7211/83. Estes números foram confirmados posteriormente em outras amostragens no decorrer da pesquisa e por outros pesquisadores, como por exemplo ZORDAN (1997) que, na pesquisa de seu trabalho de dissertação de mestrado realizado na Unicamp obteve, na média de suas amostras, um total de 50,7\% de material miúdo e do restante, $72 \%$ enquadrava-se na faixa granulométrica em estudo, como se pode observar, comparativamente, nos gráficos da Figura 4.4.

Latterza

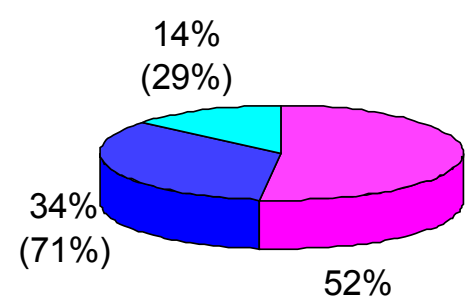

Zordan

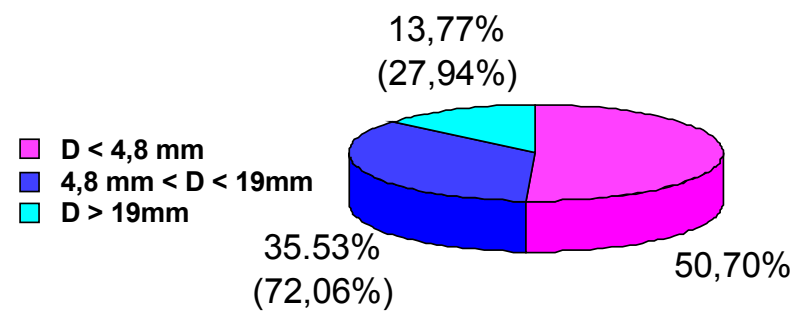

Figura 4.4 - Gráficos comparativos das curvas granulométricas do entulho 
A soma dos intervalos correspondentes à brita 0 e brita 1 apresentou-se como uma parte bastante representativa do entulho reciclado, cerca de $34 \%$ do total da amostra, fator este fundamental que impulsionou o prosseguimento dos estudos direcionados para a faixa granulométrica escolhida de agregados graúdos.

\subsubsection{Caracterização Qualitativa do Material Reciclado}

Com uma outra parte da amostra coletada, e tomando-a já peneirada, os materiais retidos em cada peneira foram espalhados, separados e devidamente identificados nas quantidades e tipos de materiais existentes para cada abertura de malha, para os agregados graúdos dentro do intervalo compreendido entre as peneiras $4,8 \mathrm{~mm}$ e $38 \mathrm{~mm}$, e definidos por: britas, pedaços de concretos, pedaços de argamassa endurecida, materiais cerâmicos e torrões. A Tabela 4.3 mostra os diferentes tipos de materiais encontrados e suas respectivas quantidades:

Os materiais passantes na peneira 4,8 mm tornam-se muito difíceis de serem identificados visualmente por possuírem diâmetro muito reduzido; além do mais, a faixa granulométrica de interesse, neste estudo, constitui-se a dos agregados graúdos do tipo brita 0 e brita 1 , conforme já exposto.

Tabela 4.3 - Natureza da composição do reciclado coletado em nov/96

\begin{tabular}{|c|c|c|c|c|c|c|}
\hline & & & peneiras & & & total da \\
\hline & $4,8 \mathrm{~mm}$ & $9,5 \mathrm{~mm}$ & $19 \mathrm{~mm}$ & $25 \mathrm{~mm}$ & $38 \mathrm{~mm}$ & amostra \\
\hline material & $(\%)$ & $(\%)$ & $(\%)$ & $(\%)$ & $(\%)$ & $(\%)$ \\
\hline britas & 23,4 & 15,9 & 4,5 & - & 100 & 19,10 \\
\hline $\begin{array}{l}\text { pedaços de } \\
\text { concretos }\end{array}$ & - & 28,9 & 22,5 & 13,7 & - & 14,60 \\
\hline argamassas & 56,9 & 36,6 & 49,0 & 65,8 & - & 46,20 \\
\hline cerâmicos & 22,7 & 18,6 & 24,10 & 13,0 & - & 19,20 \\
\hline torrões & - & - & - & 7,6 & - & 0,90 \\
\hline $\begin{array}{l}\text { total da } \\
\text { peneira }\end{array}$ & 100 & 100 & 100 & 100 & 100 & 100 \\
\hline
\end{tabular}


$\mathrm{Na}$ tabela 4.3, estão indicados as porcentagens que ficaram retidas em cada peneira; a parcela referente às argamassas ficou com $46,20 \%$ do total analisado, e a parcela de britas e pedaços de concretos juntas somam $33,70 \%$, valores estes que se apresentam semelhantes aos obtidos para a caracterização granulométrica.

Se considerarmos que os materiais argamassas (46,20\%) e cerâmicos $(19,20 \%)$ formam a grande maioria dos componentes do entulho reciclado, correspondendo a $65,40 \%$ do total da amostra, e que num processo de britagem mais intenso esses possam ser os materiais que tenham a possibilidade de se desagregar mais facilmente do que os pedaços de concretos e as britas, então poderia-se explicar a elevada quantidade da parte fina, representada na caracterização granulométrica do entulho. Porém isto não pode ser tomado como absoluto, dado ao pequeno número de amostragens ainda realizadas.

Apresenta-se a seguir, no gráfico da Figura 4.5, os dados da natureza da composição das primeiras amostras:

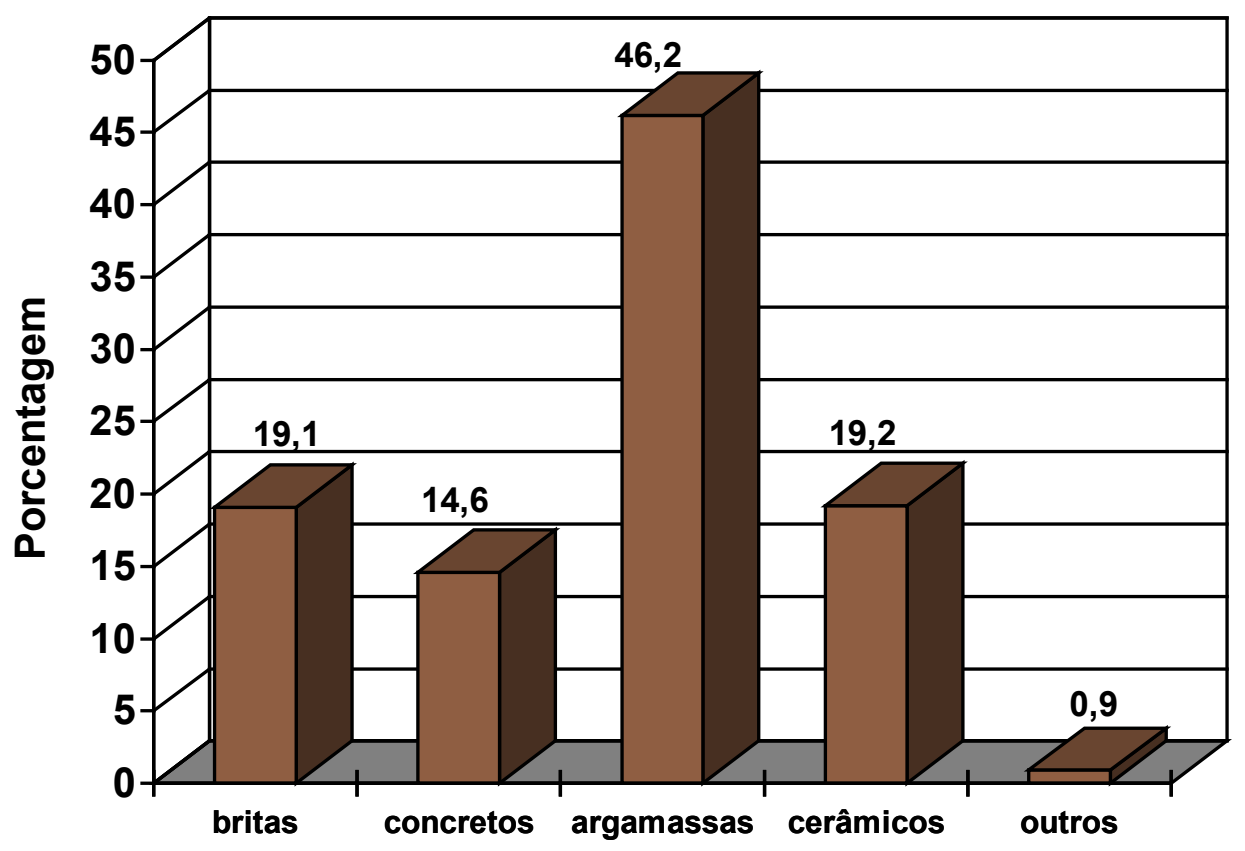

Figura 4.5 - Gráfico da composição do entulho reciclado 


\subsection{Estudo de Dosagem e Verificação de Resistência}

Posteriormente nova amostra, desta vez enviada pela administração municipal de Ribeirão Preto em janeiro de 1997, sem qualquer indicação da metodologia utilizada na coleta, foi inteiramente separada nas peneiras da série normal da ABNT, para produção de reciclados graúdos para execução de ensaios para estudo de dosagem do concreto. Desta vez, o entulho reciclado foi apenas separado nas frações das faixas granulométricas para agregado graúdo, conforme Tabela 4.4 abaixo:

Tabela 4.4 - Caracterização granulométrica do entulho

\begin{tabular}{c|c|c|c|c|c}
\hline $\mathrm{D}>38 \mathrm{~mm}$ & $19<\mathrm{D}<38 \mathrm{~mm}$ & $9,5<\mathrm{D}<19 \mathrm{~mm}$ & $4,8<\mathrm{D}<9,5 \mathrm{~mm}$ & $\mathrm{D}<4,8 \mathrm{~mm}$ & Total \\
\hline $75 \mathrm{~g}$ & $2.330 \mathrm{~g}$ & $11.385 \mathrm{~g}$ & $17.800 \mathrm{~g}$ & $45.520 \mathrm{~g}$ & $77.000 \mathrm{~g}$ \\
\hline $0,1 \%$ & $3,0 \%$ & $14,8 \%$ & $23,1 \%$ & $59,0 \%$ & $100 \%$ \\
\hline & brita 2 & brita 1 & brita 0 & $\begin{array}{c}\text { agregado } \\
\text { miúdo }\end{array}$ & \\
\hline
\end{tabular}

Pode-se notar que, na distribuição granulométrica, a parte correspondente à fração miúda ( $<<4,8 \mathrm{~mm}$ ) ficou com $59 \%$ do total da amostra e a parte graúda ficou com 41\%. A Figura 4.6 mostra a fração granulométrica desta amostra estudada.

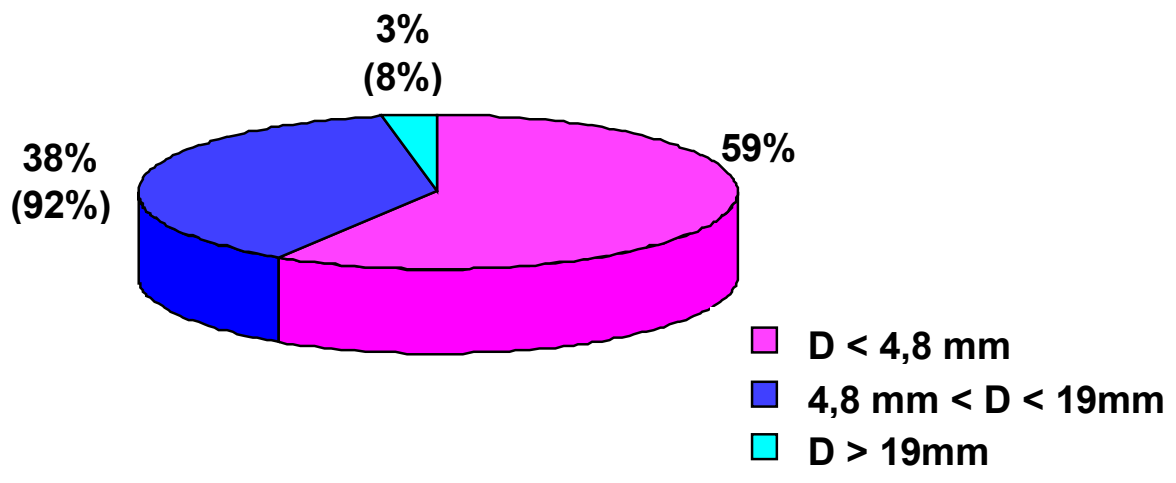

Figura 4.6 - Fração granulométrica da amostra de entulho coletada em jan/97 
A soma dos intervalos das peneiras de $19 \mathrm{~mm}$ a $9,5 \mathrm{~mm}$ e de $9,5 \mathrm{~mm}$ a $4,8 \mathrm{~mm}$ resultou num montante de aproximadamente $38 \%$ do total da amostra, correspondente a $92 \%$ da parte graúda que se enquadra na graduação brita 0 e brita 1 da NBR 7211/83.

Nesta etapa, além da subdivisão granulométrica, fez-se necessário também acrescentar as seguintes metodologias:

- Determinação das características físicas dos agregados

- Escolha do traço

- Verificação da resistência dos concretos feitos com material reciclado

\subsubsection{Características Físicas dos Agregados}

Para se determinar as características físicas dos materiais, foram realizados ensaios nos agregados graúdos reciclados, que incluíram determinação de massa unitária no estado solto e no estado compactado, e determinação da massa específica. Houve também a necessidade de se realizar estes ensaios nos agregados naturais, tanto graúdos como miúdos, a fim de, posteriormente, poder calcular o traço de referência a ser utilizado na confecção dos corposde-prova.

Todos os ensaios foram conduzidos de acordo com as normas especificadas pela $\mathrm{ABNT}$, os quais estão brevemente descritos nos parágrafos seguintes:

a) Granulometria do Agregado Graúdo

Realizou-se ensaio de peneiramento utilizando-se as peneiras descritas anteriormente, para as duas faixas de agregados graúdos naturais. As curvas granulométricas estão representadas na Figura 4.7 e 4.8: 


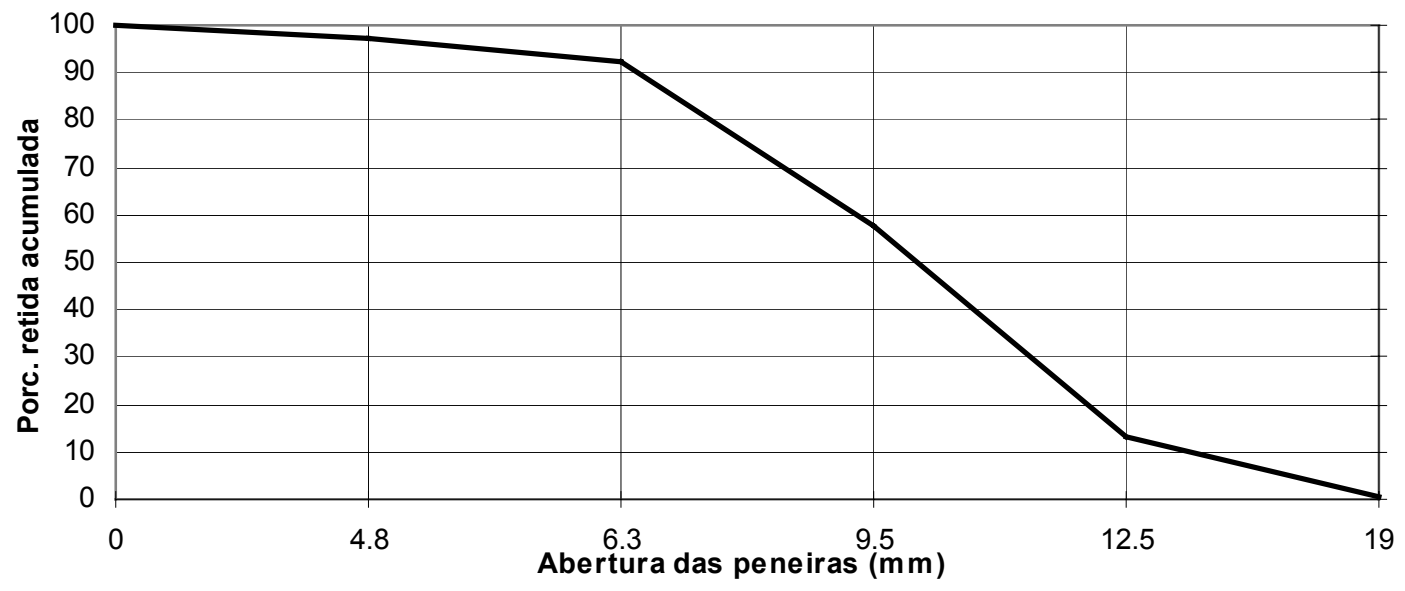

Figura 4.7 - Curva granulométrica do agregado graúdo natural:

$D_{\text {máx }}=19,0 \mathrm{~mm}$

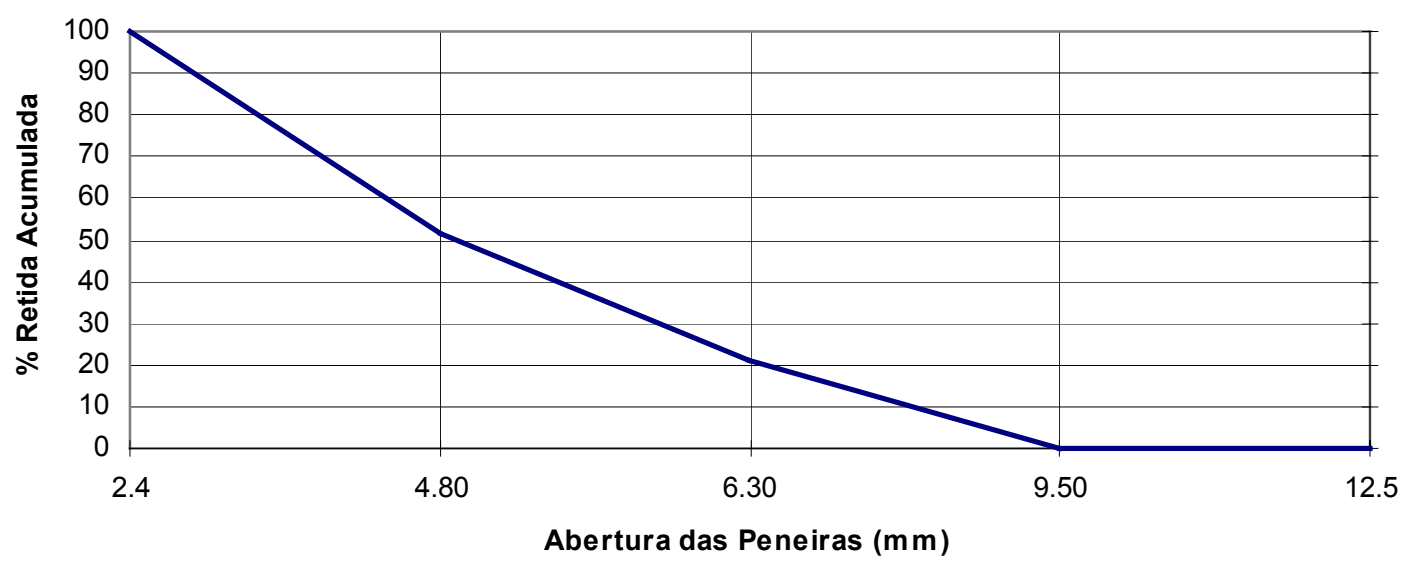

Figura 4.8 - Curva granulométrica do agregado graúdo natural: $D_{\text {máx }}=9,5 \mathrm{~mm}$

b) Massa Unitária dos Agregados Graúdos

É utilizada para converter quantidades expressas em massa para quantidades expressas em volume. Foi determinada de acordo com as recomendações da NBR 7251/82 "Agregado em Estado Solto - Determinação da Massa Unitária" e da NBR 7810/83 “Agregado em Estado Compactado Seco - Determinação da Massa Unitária”.

Para o estado solto, este ensaio consiste em se dividir a massa de uma quantidade de material; agregado graúdo, natural ou reciclado; por um volume fixo equivalente a 20 litros. A amostra é pesada dentro de um recipiente 
paralelepipédico metálico com massa igual a 5.100 g. O procedimento é repetido por 3 vezes e em seguida tira-se a média das massas unitárias.

Para o estado compactado e agregados com $\mathrm{D}_{\text {máx }} \leq 38 \mathrm{~mm}$, o procedimento deste ensaio consiste em se preencher um recipiente cilíndrico de metal em 3 camadas, conferindo-se 25 golpes e cada uma delas com um bastão de aço, nivelando-se a superfície ao final. Para agregados com $D_{\text {máx }}=9,5 \mathrm{~mm}$ e com $D_{\text {máx }}=19,0 \mathrm{~mm}$, os recipientes indicados pela norma são os de capacidade de 3 litros e 15 litros respectivamente. A massa unitária compactada é então determinada tirando-se a média de 3 medidas.

Nesta fase foram realizadas as determinações apenas para os agregados com $D_{\text {máx }}=9,5 \mathrm{~mm}$, pois o objetivo inicial era trabalhar com painéis de pequena espessura. Para o agregado natural, obteve-se o valor de $1,44 \mathrm{~kg} / \mathrm{dm}^{3}$ e de 1,56 $\mathrm{kg} / \mathrm{dm}^{3}$ para as massas unitárias no estado solto e compactado, respectivamente. $\mathrm{O}$ agregado graúdo reciclado, com mesmas dimensões, apresentou valores de $1,10 \mathrm{~kg} / \mathrm{dm}^{3}$ e $1,27 \mathrm{~kg} / \mathrm{dm}^{3}$, analogamente.

c) Massa Específica dos Agregados Graúdos

Foi determinada de acordo com as recomendações da NBR 9776/87 "Agregados - Determinação da Massa Específica de Agregados Miúdos por Meio do Frasco de Chapman" porém, modificado para agregado graúdo.

Neste ensaio coloca-se no Frasco de Chapman uma quantidade em massa de agregado graúdo que passa na peneira de malha $6,3 \mathrm{~mm}$. Utilizando-se uma quantidade de água pré-estabelecida de $300 \mathrm{ml}$, faz-se a leitura no frasco. O procedimento é repetido por 3 vezes e em seguida tira-se a média das massas específicas. Os valores obtidos foram $2,88 \mathrm{~kg} / \mathrm{dm}^{3}$ e $2,45^{*} \mathrm{~kg} / \mathrm{dm}^{3}$ para o agregado natural e para o agregado graúdo reciclado, respectivamente. Pelos mesmos motivos, utilizou-se apenas apenas agregados com $D_{\text {máx }}=9,5 \mathrm{~mm}$.

d) Granulometria do Agregado Miúdo

Faz-se necessário a realização deste ensaio para determinação do Módulo de Finura da areia natural, que será utilizado no cálculo do consumo de cimento e do traço. Para realizar este ensaio, utiliza-se uma quantidade de $1.100 \mathrm{~g}$ de areia, colocando a amostra no conjunto de peneiras a fim de ficar 10 minutos no aparelho de peneiramento. Depois a quantidade de material de cada peneira é pesada e os resultados apresentados. A faixa granulométrica correspondente

\footnotetext{
*Ver Obs. na pág. 49
} 
a este agregado foi a estabelecida pela norma como "Areia Média", com $\mathrm{D}_{\text {máx }}=2,4 \mathrm{~mm}$, apresentando Módulo de Finura (MF) igual a 2,34. Acurva granulométrica para este agregado pode ser vista na Figura 4.9:

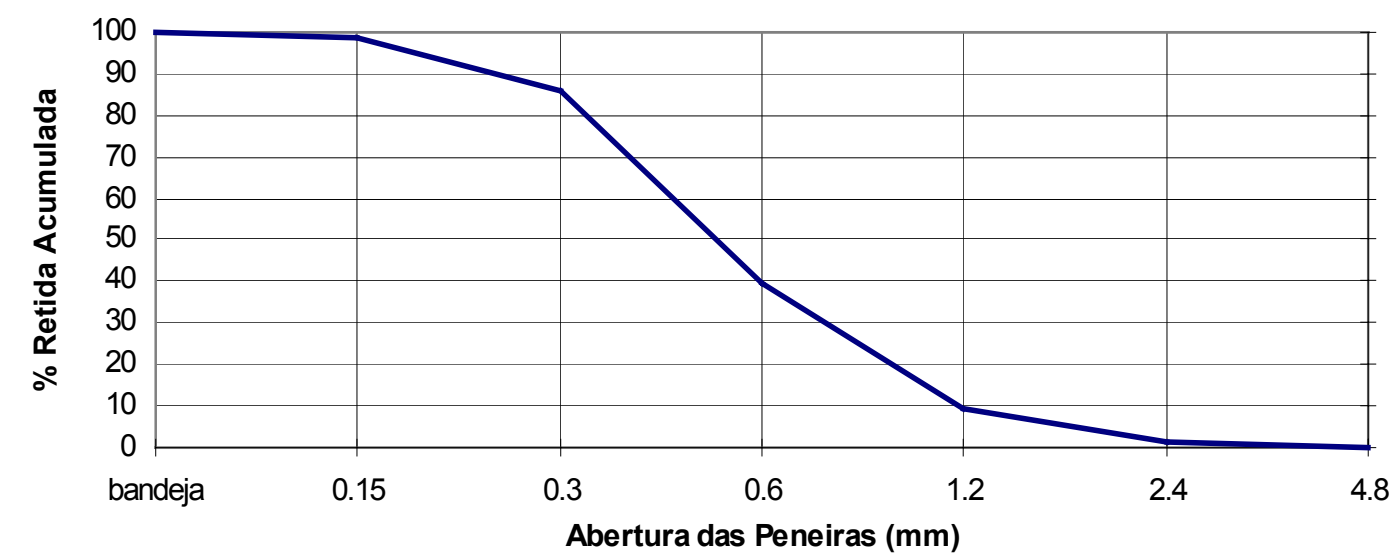

Figura 4.9 - Curva granulométrica do agregado miúdo

e) Massa Unitária do Agregado Miúdo

Foi determinada de acordo com as recomendações da NBR 7251/82. Para a areia este ensaio consiste em se dividir o peso de uma quantidade de agregado miúdo por um volume fixo equivalente a 15 litros. A amostra é pesada dentro de um recipiente paralelepipédico metálico com massa igual a $4.200 \mathrm{~g}$. Repete-se o ensaio por 3 vezes e em seguida tira-se a média das massas unitárias que teve como resultado o valor de $1,46 \mathrm{~kg} / \mathrm{dm}^{3}$.

\section{f) Massa Específica do Agregado Miúdo}

Foi determinada de acordo com as recomendações da NBR 9776/87. Este ensaio consiste em se colocar no Frasco de Chapman uma massa de agregado miúdo que passa na peneira de malha $4,8 \mathrm{~mm}$. Utiliza-se, para este ensaio, uma massa de areia de $500 \mathrm{~g}$ e, para se fazer a leitura no frasco utiliza-se uma quantidade de água de $300 \mathrm{ml}$. O procedimento é repetido por 3 vezes e então tira-se a média das massas específicas. $O$ valor obtido foi de $2,60 \mathrm{~kg} / \mathrm{dm}^{3}$.

Apresenta-se a seguir, na Tabela 4.5 um resumo das características físicas dos materiais naturais e da amostra de reciclados: 
Tabela 4.5 - Características físicas dos reciclados (amostra jan/97) para agregados com $D_{\text {máx }}=9,5 \mathrm{~mm}$

\begin{tabular}{lccc}
\hline & \multicolumn{2}{c}{ agregado graúdo } \\
\cline { 2 - 4 } \multicolumn{1}{c}{ Características físicas } & areia natural & natural & reciclado \\
\hline Massa unitária estado solto $\left(\mathrm{kg} / \mathrm{dm}^{3}\right)$ & 1,46 & 1,44 & 1,10 \\
Massa unitária estado compactado $\left(\mathrm{kg} / \mathrm{dm}^{3}\right)$ & - & 1,56 & 1,27 \\
\hline Massa específica $\left(\mathrm{kg} / \mathrm{dm}^{3}\right)$ & 2,60 & 2,88 & $2,45^{*}$ \\
\hline
\end{tabular}

* Obs.: O ensaio do Frasco de Chapman Modificado para determinação da massa específica do agregado graúdo mostrou-se inadequado quando se trata do material reciclado, devido a sua grande absorção. Nos ensaios posteriores, onde foram utilizados outros métodos, este fato será confirmado.

Comparando-se os valores da tabela, pode-se observar que a massa unitária média no estado solto do agregado graúdo reciclado ficou em torno de $23,61 \%$ menor do que aquela para agregado natural de peso normal. No estado compactado, o agregado reciclado apresentou-se $18,59 \%$ menor que o agregado natural e, para massa específica, o reciclado apresentou-se 14,93\% menor. Tendo-se determinado os valores das características físicas dos materiais a serem utilizados, passou-se para o cálculo do traço.

\subsubsection{Escolha do Traço}

Em primeira instância calculou-se os traços experimentais utilizando-se os agregados naturais e, a partir destes, os demais traços foram sendo adaptados para os agregados reciclados, devido às suas características físicas diferentes.

Assim, duas dosagens para o concreto de referência, uma com $\mathrm{D}_{\text {máx }}$ da fração graúda igual a $19,0 \mathrm{~mm}$ e a outra com $\mathrm{D}_{\text {máx }}$ igual a $9,5 \mathrm{~mm}$; tendo em ambas, como agregado miúdo areia média natural com $\mathrm{D}_{\text {máx }}$ igual a 2,4 $\mathrm{mm}$ e módulo de finura previamente determinado $\mathrm{MF}=2,34$, foram definidas para uma resistência à compressão aos 28 dias $\left(f_{\mathrm{c} 28}\right)$ igual a 22,0 $\mathrm{MPa}$. Isto significa dizer que o concreto deve atingir uma resistência característica $\left(f_{c k}\right)$ de aproximadamente 15,0 $\mathrm{MPa}$.

Deve-se observar que o fato de se ter adotado um $\mathrm{f}_{\mathrm{ck}}$ igual a $15 \mathrm{MPa}$, foi por ser este um valor freqüentemente utilizado nas obras de concreto estrutural de baixa e média resistências. 
Adotando-se o método de dosagem do ACI para determinação do consumo de cimento, e para o fck estimado de $15 \mathrm{MPa}$, o traço em massa resultante, para o concreto contendo agregado graúdo com $\mathrm{D}_{\text {máx }}=9,5 \mathrm{~mm}$ foi $1: 2,83: 2,33$, com consumo de cimento igual a $335 \mathrm{~kg} / \mathrm{m}^{3}$ e fator água/cimento $(\mathrm{a} / \mathrm{c})$ igual a 0,68 . Para o concreto contendo agregado graúdo com $\mathrm{D}_{\text {máx }}=19,0 \mathrm{~mm}$ o traço resultante foi $1: 3,06: 3,20$, com consumo de cimento igual a $300 \mathrm{~kg} / \mathrm{m}^{3} \mathrm{e}$ fator água/cimento $(\mathrm{a} / \mathrm{c})$ também igual a 0,68 .

Os materiais utilizados foram o Cimento Portland classe CP II E-32, areia natural do rio Mogi e agregado graúdo proveniente da britagem de basalto da região. A Tabela 4.6 mostra as quantidades, em massa, por metro cúbico de concreto adotadas para os concretos de referência.

Tabela 4.6 - Quantidades utilizadas para os concretos de referência

\begin{tabular}{lcc}
\hline \multicolumn{1}{c}{ materiais } & \multicolumn{2}{c}{ quantidades $\left(\mathrm{kg} / \mathrm{m}^{3}\right)$} \\
\hline Cimento ( CP II E-32 ) & $\mathrm{D}_{\text {máx }}=19,0 \mathrm{~mm}$ & $\mathrm{D}_{\text {máx }}=9,5 \mathrm{~mm}$ \\
\hline areia natural( $\left.\mathrm{D}_{\text {máx }}=2,4 ; \mathrm{MF}=2,34\right)$ & 300 & 335 \\
\hline agregado graúdo ( basalto ) & 918 & 949 \\
\hline água & 960 & 780 \\
\hline
\end{tabular}

\subsubsection{Verificação da Resistência dos Concretos Preparados com Material Reciclado}

Com os traços determinados para os concretos de referência, partiu-se para execução de corpos-de-prova para verificação de resistência. Nos concretos com reciclados, o agregado graúdo natural foi substituído em massa. Para determinação das características, tanto dos concretos feitos com agregados naturais, como dos concretos feitos com agregados reciclados, diferentes combinações foram consideradas:

- Concreto de Referência: é aquele com $0 \%$ de agregado graúdo reciclado, ou seja, utilizou-se apenas agregado graúdo natural.

- $100 \%$ Reciclado : constitui-se no concreto com substituição total do agregado graúdo natural pelo graúdo reciclado. 
- 50\% natural $+50 \%$ reciclado: é o concreto contendo metade da quantidade de material graúdo natural substituído pelo graúdo reciclado.

Todos os concretos tiveram como agregado miúdo a areia natural caracterizada anteriormente.

Corpos-de-provas cilíndricos de $10 \mathrm{~cm}$ de diâmetro e $20 \mathrm{~cm}$ de altura foram moldados para realização dos ensaios para determinação da resistência à compressão axial e diametral dos concretos, utilizando-se as recomendações da norma NBR 5738 "Moldagem e Cura de Corpos-de-Prova de Concreto Cilíndricos ou Prismáticos".

Da mesma forma, para determinação da consistência do concreto tomou-se as especificações da NBR 7223 "Concreto - Determinação da Consistência pelo Abatimento do Tronco de Cone". Após desmoldados, os corpos-de-prova foram curados submersos em tanques com água até a data dos ensaios.

Dando prosseguimento a esta fase, foi realizada a avaliação de resistência nos exemplares conforme a programação de ensaios definida.

Foram moldados 12 exemplares com $\mathrm{D}_{\text {máx }}$ igual a 19,0 mm, distribuídos em 2 séries, uma com 6 exemplares para o concreto de referência e outra com 6 exemplares para o concreto com $100 \%$ de substituição do agregado graúdo natural.

Para o agregado graúdo com $D_{\text {máx }}$ igual a $9,5 \mathrm{~mm}$, foram moldados 18 exemplares, distribuídos em 3 séries iguais. A série 1 refere-se ao concreto de referência; as séries 2 e 3 referem-se, respectivamente, aos concretos com 50\% e $100 \%$ de agregado graúdo reciclado, em substituição ao agregado graúdo natural. Todos os exemplares eram cilíndricos com diâmetro de $10 \mathrm{~cm}$ e altura de $20 \mathrm{~cm}$. A Tabela 4.7 apresenta o plano de ensaio realizado com as séries definidas: 
Tabela 4.7 - Plano de ensaios

\begin{tabular}{|c|c|c|c|c|c|}
\hline \multirow{3}{*}{$\begin{array}{l}\mathrm{D}_{\text {máx }}= \\
(\mathrm{mm})\end{array}$} & \multirow{3}{*}{$\begin{array}{l}\text { concreto com } \\
\text { agregado } \\
\text { graúdo } \\
\end{array}$} & \multirow{3}{*}{ Série } & \multicolumn{3}{|c|}{ Número de exemplares } \\
\hline & & & \multicolumn{2}{|c|}{ compr. axial } & \multirow{2}{*}{$\begin{array}{c}\text { compr.diametral } \\
28 \text { dias } \\
\end{array}$} \\
\hline & & & 7 dias & 28 dias & \\
\hline \multirow[t]{2}{*}{19,0} & natural & 1 & 3 & 3 & - \\
\hline & $100 \%$ reciclado & 2 & 3 & 3 & - \\
\hline \multirow{3}{*}{9,5} & natural & 1 & 2 & 2 & 2 \\
\hline & $\begin{array}{l}50 \% \text { natural }+ \\
50 \% \text { reciclado }\end{array}$ & 2 & 2 & 2 & 2 \\
\hline & $100 \%$ reciclado & 3 & 2 & 2 & 2 \\
\hline
\end{tabular}

Deve-se observar que o ensaio de compressão diametral não foi realizado para o concreto com agregado $D_{\text {máx }}=19,0 \mathrm{~mm}$ pois, a princípio, tinha-se em mente fazer como primeira aplicação prática a moldagem de painéis leves de vedação de pequena espessura, de forma que as atenções foram direcionadas, nesta etapa, para a graduação brita $0\left(D_{\text {máx }}=9,5 \mathrm{~mm}\right)$.

Tendo em vista a pouca quantidade de materiais para a moldagem de cada série, o concreto foi misturado manualmente, da forma convencional, em amassadeira de chapa. Em cada série os materiais foram misturados a seco, com posterior adição da água de amassamento. As proporções entre os materiais para cada série, foram iguais ao do concreto de referência, sendo que, para as 2 graduações, no concreto com $100 \%$ de agregado reciclado, houve a necessidade de se acrescentar mais água, resultando num fator água/cimento $(\mathrm{a} / \mathrm{c})$ maior. Portanto, para estes concretos, o fator $\mathrm{a} / \mathrm{c}$ está baseado na quantidade de água total da mistura, considerando-se a água adicionada.

Os testes de resistência foram conduzidos conforme NBR 5739 - "Ensaios de Compressão de Corpos de Prova Cilíndricos de Concreto", em idades de 7 e 28 dias. Para ensaios por compressão diametral, utilizou-se as prescrições da NBR 7222 - "Argamassas e Concretos - Determinação da Resistência à Tração por Compressão Diametral de Corpos-de-prova Cilíndricos". Com base nos resultados da análise experimental desenvolvida, são feitos alguns comentários a respeito do comportamento dos corpos-de-prova confeccionados e dos materiais utilizados.

A Tabela 4.8 apresenta os resultados dos ensaios, com seus respectivos valores do fator a/c, do abatimento e das resistências médias à compressão e à tração: 
Tabela 4.8 - Resultados dos ensaios de verificação de resistência

\begin{tabular}{|c|c|c|c|c|c|c|}
\hline \multirow[t]{2}{*}{$\begin{array}{l}\mathrm{D}_{\text {máx }} \\
(\mathrm{mm})\end{array}$} & \multirow[t]{2}{*}{$\begin{array}{l}\text { tipo de } \\
\text { agregado } \\
\text { graúdo }\end{array}$} & \multirow[t]{2}{*}{$\begin{array}{l}\text { fator } \\
a / c\end{array}$} & \multirow[t]{2}{*}{$\begin{array}{c}\text { abatimento } \\
(\mathrm{mm})\end{array}$} & \multicolumn{2}{|c|}{$\begin{array}{l}\text { resistência à } \\
\text { compressão } \\
(\mathrm{MPa})\end{array}$} & \multirow{2}{*}{$\begin{array}{c}\text { resistência } \\
\text { à tração } \\
(\mathrm{MPa}) \\
28 \text { dias }\end{array}$} \\
\hline & & & & 7 dias & 28 dias & \\
\hline \multirow[t]{3}{*}{19,0} & natural & 0,68 & 13 & $15,4(1,00)$ & $21,8(1,00)$ & - \\
\hline & $100 \%$ reciclado & 0,83 & 15 & $13,2(0,86)$ & $18,5(0,85)$ & - \\
\hline & natural & 0,68 & 18 & $15,2(1,00)$ & $22,3(1,00)$ & $2,59(1,00)$ \\
\hline \multirow[t]{2}{*}{9,5} & $\begin{array}{l}50 \% \text { natural }+ \\
50 \% \text { reciclado }\end{array}$ & 0,68 & 10 & $19,2(1,26)$ & $29,0(1,30)$ & $2,85(1,10)$ \\
\hline & $100 \%$ reciclado & 0,74 & 0 & $18,2(1,20)$ & $27,0(1,21)$ & $2,72(1,05)$ \\
\hline
\end{tabular}

A resistência média à compressão, $\mathrm{f}_{\mathrm{c} 28}$, dos concretos de referência, atingiu o valor previsto no estudo de dosagem. O concreto com agregado graúdo reciclado com $D_{\text {máx }}=19,0 \mathrm{~mm}$ apresentou $85 \%$ da resistência média do concreto de referência aos 7 e aos 28 dias, necessitando aproximadamente $20 \%$ a mais de água para o mesmo abatimento. Resultados estes previsíveis em se tratando de agregados graúdos reciclados de rejeitos de construção e demolição (C\&D), por serem mais porosos e apresentarem maior índice de vazios, como poderá ser constatado adiante.

Ao contrário do que se esperava, para os agregados com $\mathrm{D}_{\text {máx }}=9,5 \mathrm{~mm}$, todos os concretos com agregados graúdos reciclados tiveram resistências médias mais altas que o de referência, aumentando, inclusive, com a idade. As resistências à tração, foram aproximadamente iguais nas 3 séries. $\mathrm{O}$ concreto com $50 \%$ de agregado reciclado, apresentou melhor desempenho que aquele com $100 \%$, como era de se esperar.

Para os concretos utilizando-se agregados com $\mathrm{D}_{\text {máx }}=9,5 \mathrm{~mm}$, todas as misturas contendo agregados reciclados apresentaram valores de abatimento mais baixos em comparação com a mistura do concreto de referência. Isto poderia decorrer principalmente devido à absorção de água do agregado reciclado durante a mistura do concreto dado à grande quantidade de argamassas e materiais cerâmicos porosos constituintes da sua composição; fato que foi verificado quando da realização do ensaio para determinação da absorção dos agregados, apresentado no item 4.4.3.

Com o aumento da porcentagem de agregado reciclado usado na mistura do concreto, os respectivos valores de abatimento diminuíram. Tais tendências e comportamentos serão investigados com os estudos realizados no concreto 
fresco, através de ensaios de perda de abatimento, e estão apresentados no capítulo 5.

A análise dos resultados dos estudos de viabilidade quanto à verificação da resistência à compressão axial e diametral apresentou-se positiva para que se desse continuidade à investigação proposta. Para dar prosseguimento aos estudos necessitou-se obter mais material reciclado.

\subsection{Coleta da Amostra Representativa do Entulho Reciclado da Usina de Ribeirão Preto}

Uma grande amostra foi coletada na Estação de Reciclagem de Ribeirão Preto, em conformidade com a NBR 7216 "Amostragem de Agregados", para amostragem em bica corrida. Com um caminhão basculante com capacidade superior a $5 \mathrm{~m}^{3}$, coletou-se o material no meio da linha de produção, ou seja, antes de se formarem as pilhas de resíduos triturados, caindo direto da esteira na caçamba do caminhão, o qual fez o transporte da usina para o Laboratório de Estruturas da EESC - USP.

De acordo com a NBR 10.007 "Amostragem de Resíduos", retirou-se nova amostra, diretamente da pilha de reciclados. Esta nova amostra foi reduzida, a fim de serem realizados ensaios de granulometria, em laboratório, conforme a NBR 9941 "Redução de Amostra de Campo de Agregados para Ensaios de Laboratório".

\subsubsection{Determinação Granulométrica do Entulho Reciclado}

Uma vez coletado o material reciclado na usina, fez-se a separação em amostras representativas que foram utilizadas nos ensaios de laboratório. Para isto utilizou-se o procedimento definido pela NBR 9941 "Redução de Amostras de Campo de Agregados para Ensaios de Laboratório", descrito anteriormente. 
A curva granulométrica do entulho reciclado em bica corrida, apresenta-se na Figura 4.7:

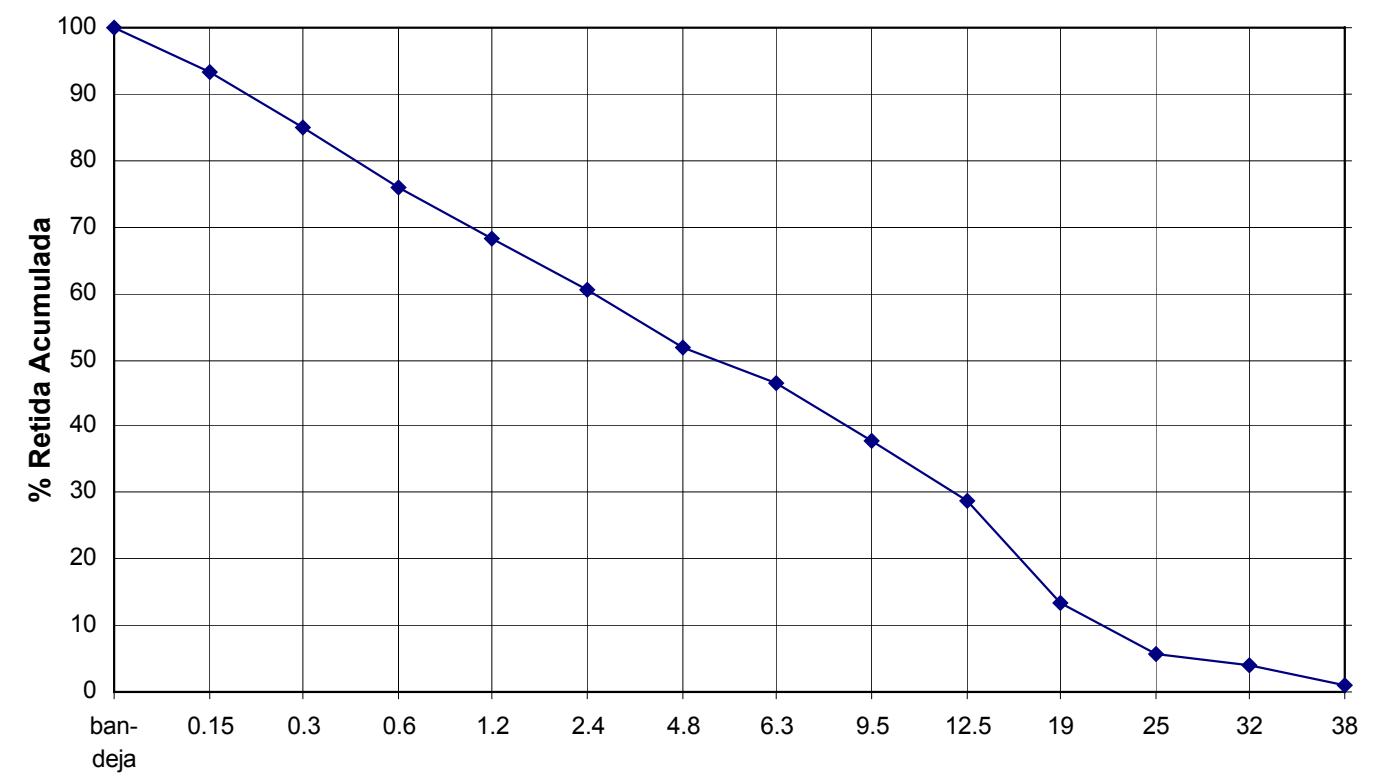

Abertura das Peneiras ( $\mathrm{mm})$

Figura 4.10 - Curva granulométrica da amostra coletada em abril/97: Bica corrida

Estes ensaios mostraram que a quantidade de agregados reciclados miúdos, passante na peneira $4,8 \mathrm{~mm}$, foi de $48 \%$, e do restante, $74 \%$ enquadrava-se na faixa granulométrica correspondente à brita 0 e brita 1. Estes resultados demonstraram-se coincidentes com os das primeiras amostragens.

Para fins unicamente de comparação, a partir dos resultados de uma amostra previamente analisada, coletada na Usina de Reciclagem de Londrina-PR, comparou-se a curva granulométrica do reciclado desta usina com as curvas das amostras de entulho reciclado em bica corrida, obtidas neste estudo, as quais estão apresentadas na Figura 4.8: 


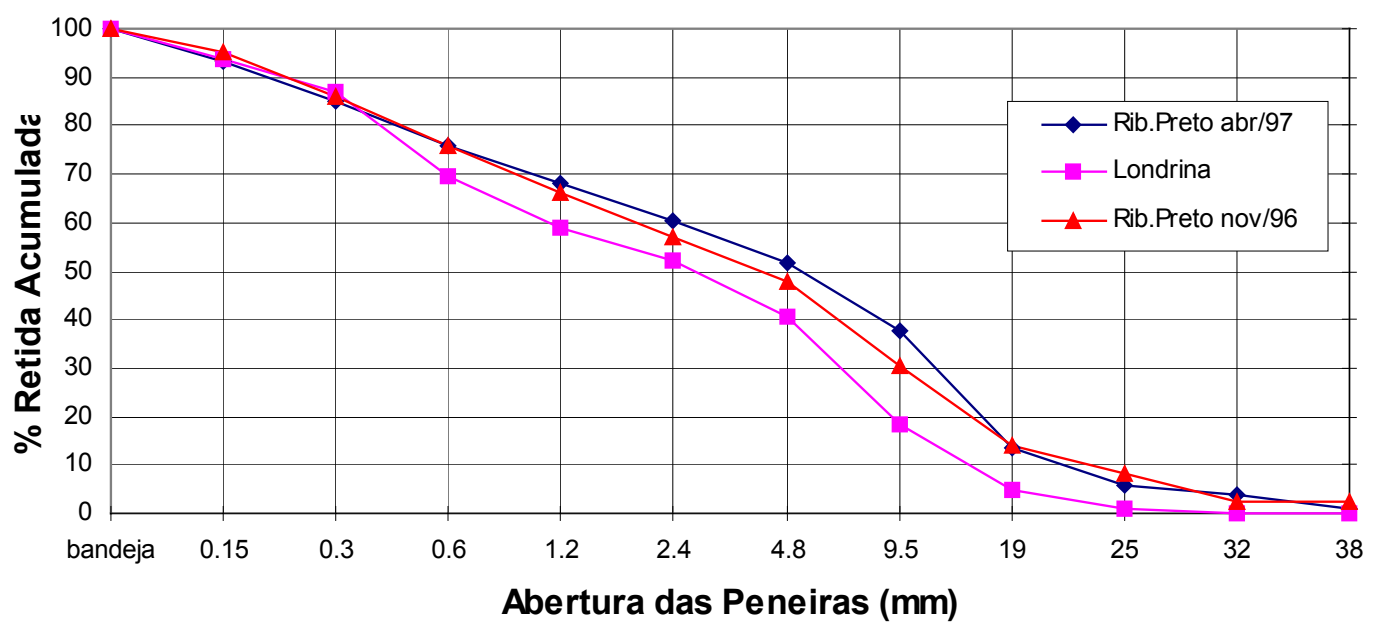

Figura 4. 11 - Curvas granulométricas comparativas do entulho reciclado: Usinas de Ribeirão Preto e Londrina

Pode-se notar pelos gráficos que, apesar das amostras de Ribeirão Preto terem sido colhidas em épocas diferentes e, até mesmo em cidades diferentes, houve uma semelhança nos resultados apresentados, demonstrando uma tendência nas características dos entulhos reciclados.

Observa-se ainda que a curva referente à amostra de Londrina apresenta uma declividade maior em relação às outras duas. Isto significa que os agregados daquela usina possuem, de forma geral, graduação mais fina do que os agregados provenientes da usina de Ribeirão Preto. Este fato pode ser explicado, talvez, por causa do processo diferenciado de britagem, possuindo 2 britadores em série, sendo o segundo um moinho de martelos, conforme já mostrado no item 3.2.6.

Para se ter uma melhor compreensão das características dos agregados de entulho reciclado, pelo menos nas regiões onde foram estudados, comparou-se também os gráficos das divisões das frações granulométricas dos reciclados desta última amostra, com os valores apresentados nos estudos de viabilidade e os obtidos na usina de Londrina. Os gráficos podem ser vistos na Figura 4.8:

As 2 primeiras amostras são as obtidas neste estudo; a terceira consiste na amostra caracterizada por Zordan (1997), procedente da mesma usina de reciclagem (Ribeirão Preto) em diferente data, e por fim apresenta-se a fração granulométrica da amostra coletada na usina de Londrina - PR. 


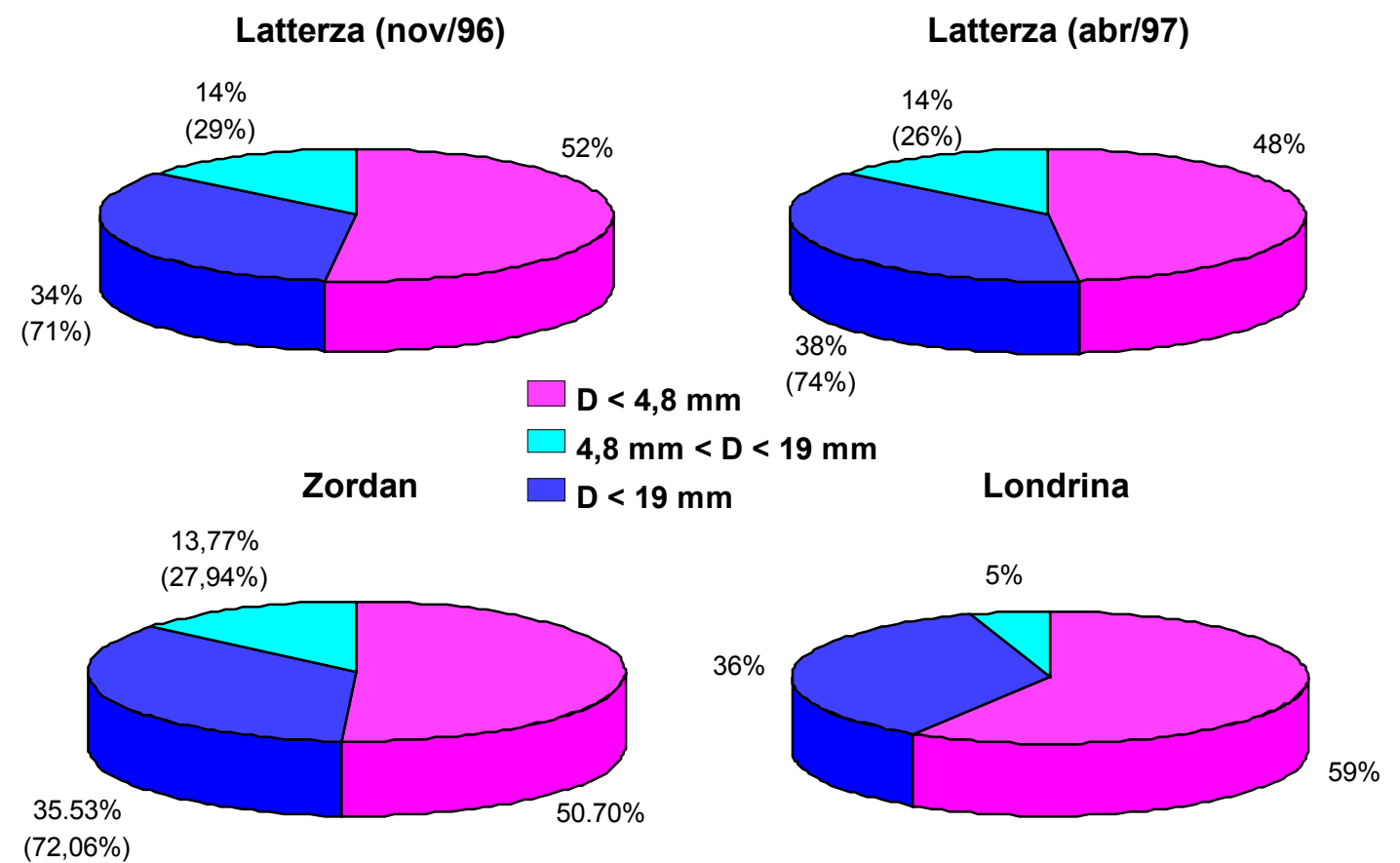

Figura 4.12 - Gráficos comparativos das frações granulométricas do entulho reciclado

Em todos os casos, a parte miúda constituiu-se a grande parcela do entulho reciclado, com valores quase sempre maiores que $50 \%$. A faixa granulométrica de maior ênfase nesta pesquisa também apresentou valores bastante signficativos em todos os casos, mantendo-se em torno dos $35 \%$, em média.

Após análise das características granulométricas do entulho reciclado como um todo (bica corrida), determinou-se também as curvas granulométricas referente a cada graduação estudada, ou seja brita 0 e brita 1 separadamente, as quais apresentam-se nas Figuras 4.13 e 4.14 . 


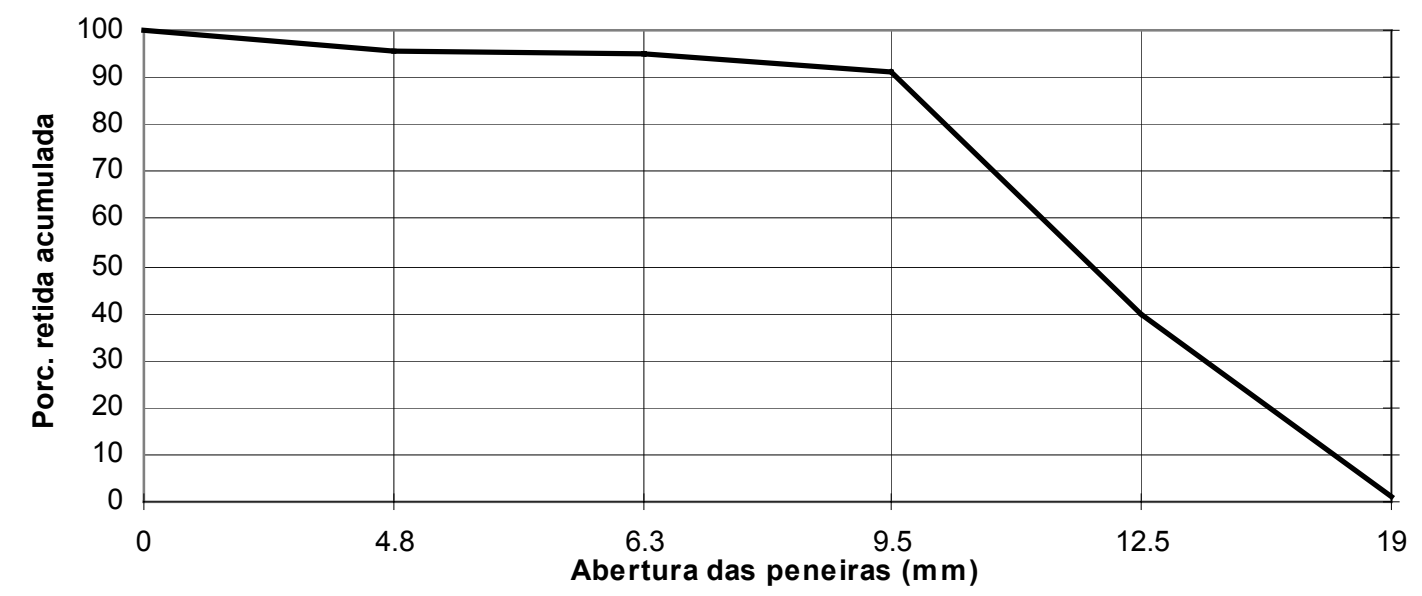

Figura 4.13 - Curva granulométrica do agregado graúdo reciclado: $D_{\text {máx }}=19,0 \mathrm{~mm}$

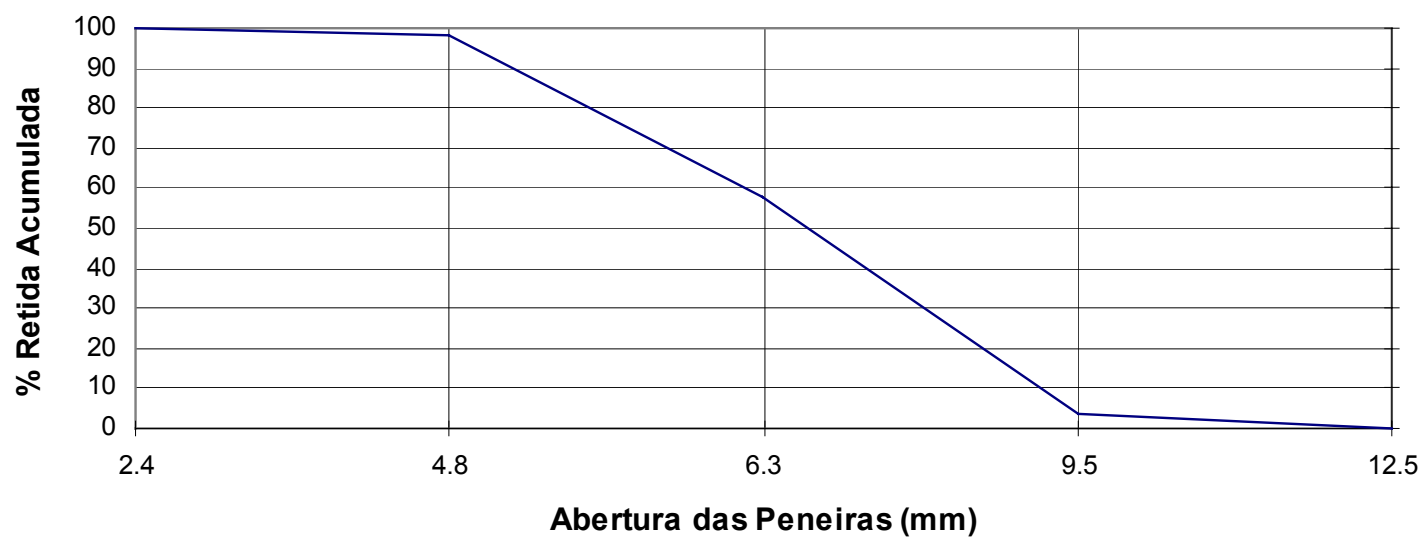

Figura 4.14 - Curva granulométrica do agregado graúdo reciclado: $D_{\text {máx }}=9,5 \mathrm{~mm}$ 


\subsubsection{Natureza da Composição do Entulho Reciclado}

Para determinação da natureza da composição desta nova amostra coletada, foram executados ensaios similares aos realizados nos estudos preliminares, cujos resultados constam no gráfico da Figura 4.15:

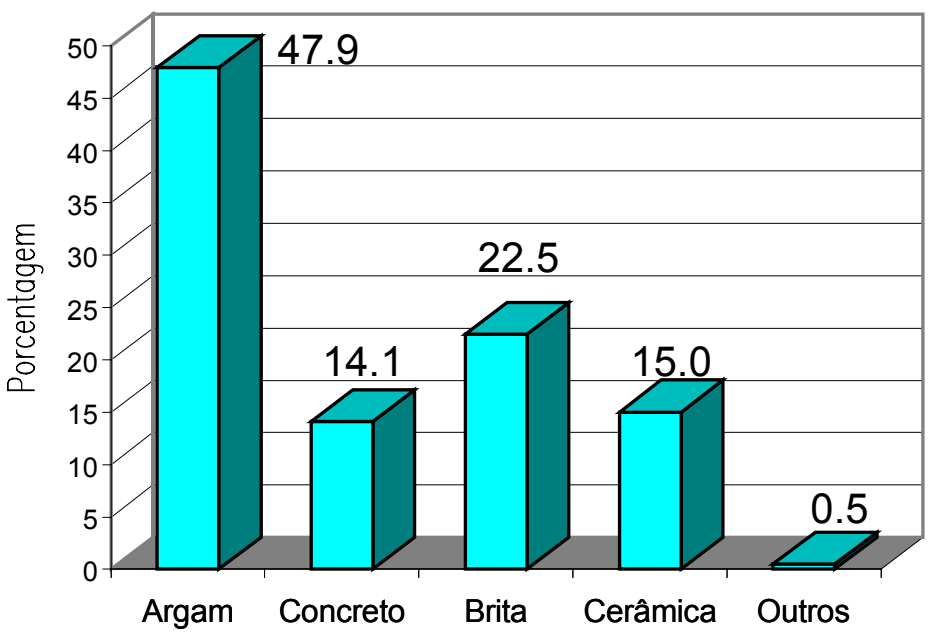

Figura 4.15 - Gráfico da natureza da composição do agregado graúdo reciclado, coletado em bica corrida (abr/97)

Nesta amostra a argamassa também obteve a maior quantidade em relação ao total de agregados analisados, vindo logo em seguida a brita. Pedaços de concreto e brita somaram $36,5 \%$ do total da amostra, ficando próximos dos valores obtidos nos estudos preliminares $(33,70 \%)$.

Da mesma forma foram feitas comparações para a natureza da composição para as amostras das usinas analisadas anteriormente, como pode ser visto na Figura 4.16: 


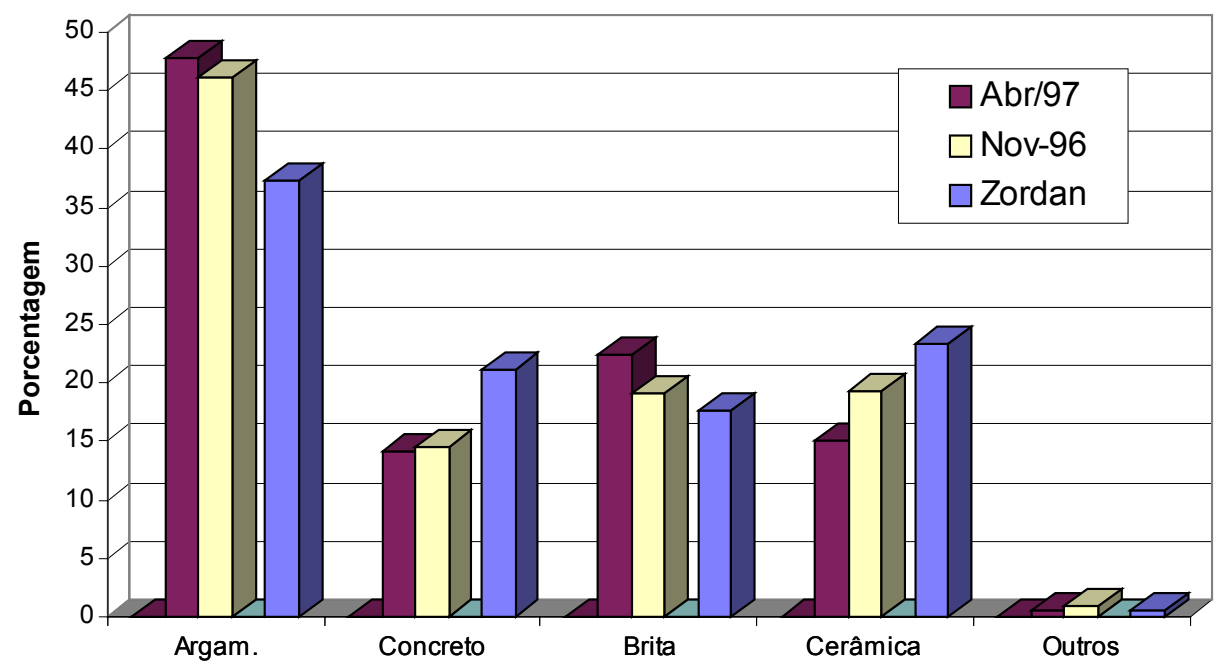

Figura 4.16 - Gráfico comparativo da natureza de composição dos agregados graúdos reciclados (bica corrida)

Observando o gráfico, pode-se notar que em todos as amostras apresentadas, pedaços de argamassas constituem a grande parcela do entulho reciclado, vindo logo em seguida as britas e os materiais cerâmicos. Na amostragem analisada por Zordan, pedaços de concretos e britas somam 38,8\%, próximo aos valores obtidos neste estudo, de 36,35\% (média).

Para a amostra de reciclados deste estudo, foi determinada também a natureza da composição para cada dimensão máxima do agregado, mostrada nos gráfico da Figuras $4.17\left(D_{\text {máx }}=19,0 \mathrm{~mm}\right)$ e Figuras $4.18\left(D_{\text {máx }}=9,5 \mathrm{~mm}\right)$ :

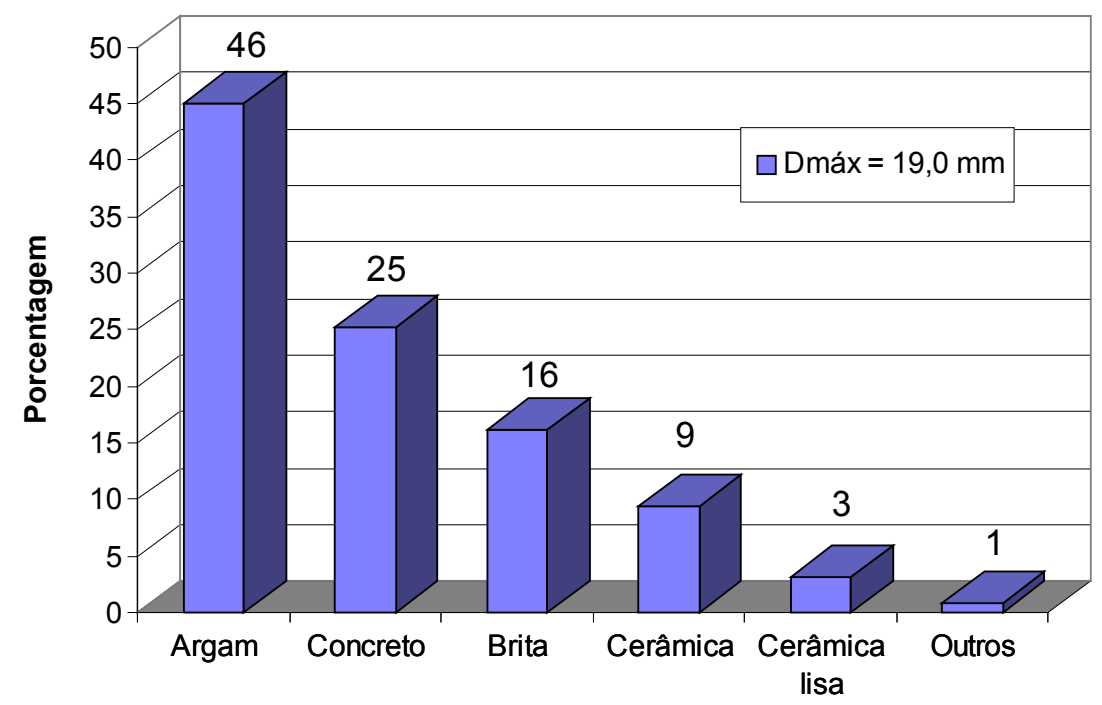

Figura 4.17 - Natureza da composição do agregado graúdo reciclado: $D_{\text {máx }}=19,0 \mathrm{~mm}$ 


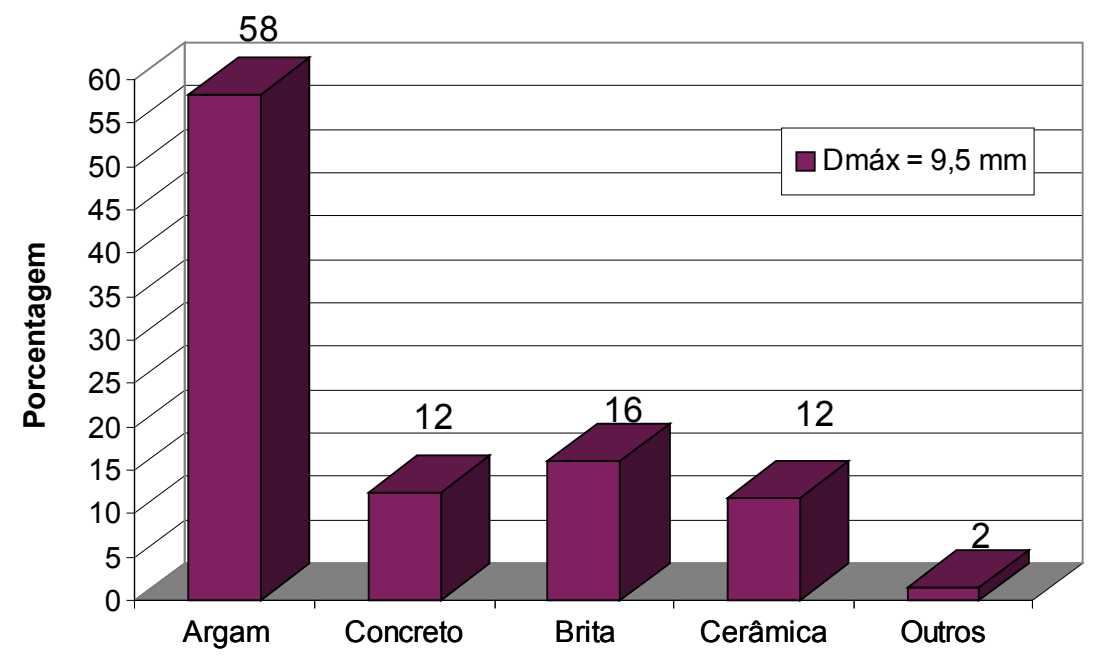

Figura 4.18 - Natureza da composição do agregado graúdo reciclado: $D_{\text {máx }}=9,5 \mathrm{~mm}$

\subsubsection{Características Físicas dos Agregados Graúdos Reciclados Utilizados}

A determinação das características físicas do material utilizado a partir de então, foi realizada com os mesmos ensaios prescritos nos estudos de viabilidade.

Durante o preparo dos concretos para os estudos preliminares, e posteriormente para os concretos utilizados nos painéis, objeto do capítulo 6 , notou-se que os agregados reciclados influenciavam o concreto em propriedades como abatimento e resistência à compressão. Entretanto, quanto a resistência à tração, ainda não se tinha dados suficientes para perceber alguma influência.

O material graúdo reciclado utilizado para a confecção dos concretos foi o proveniente da amostra de entulho coletada em abril de 1997, cuja curva granulométrica e caracterização da natureza da composição estão apresentadas nos itens anteriores. A graduação dos agregados utilizados foi aquela caracterizada como brita 0 e brita 1 da NBR 7211/83. A determinação das características físicas, para os agregados graúdos reciclados desta amostra, foi realizada de acordo com os ensaios prescritos na NBR 9937/87 - "Agregados Determinação da Absorção e da Massa Específica de Agregado Graúdo". 
Para os graúdos naturais, estes ensaios não foram realizados, uma vez que já se possuíam os valores determinados pelo ensaio do Frasco de Chapman modificado, válido para esses agregados. As características físicas dos graúdos reciclados estão apresentadas, separadamente, para cada uma das graduações (Tabela 4.9), e apresenta-se também as características físicas referentes aos agregados naturais, a título de comparação (Tabelas 4.10):

Tabela 4.9 - Características físicas dos agregados graúdos reciclados

\begin{tabular}{lcc}
\hline \multicolumn{1}{c}{ Características físicas } & \multicolumn{2}{c}{ agregado graúdo } \\
\cline { 2 - 3 } & $\mathrm{D}_{\text {máx }}=19,0 \mathrm{~mm}$ & $\mathrm{D}_{\text {máx }}=9,5 \mathrm{~mm}$ \\
\hline Massa unitária estado solto $\left(\mathrm{kg} / \mathrm{dm}^{3}\right)$ & 1,11 & 1,10 \\
Massa unitária estado compactado $\left(\mathrm{kg} / \mathrm{dm}^{3}\right)$ & 1,26 & 1,26 \\
\hline Massa específica $\left(\mathrm{kg} / \mathrm{dm}^{3}\right)$ & 2,32 & 2,36 \\
\hline
\end{tabular}

Tabela 4.10 - Características físicas dos agregados miúdo e graúdo naturais

\begin{tabular}{lccc}
\hline \multirow{2}{*}{ Características físicas } & areia natural & \multicolumn{2}{c}{ agregado graúdo } \\
\cline { 2 - 4 } & \multicolumn{3}{c}{$\mathrm{D}_{\text {máx }}(\mathrm{mm})$} \\
\cline { 2 - 4 } & 2,4 & 19,0 & 9,5 \\
\hline Massa unitária estado solto $\left(\mathrm{kg} / \mathrm{dm}^{3}\right)$ & 1,46 & 1,45 & 1,34 \\
Massa unitária estado compactado $\left(\mathrm{kg} / \mathrm{dm}^{3}\right)$ & - & 1,60 & 1,53 \\
\hline Massa específica $\left(\mathrm{kg} / \mathrm{dm}^{3}\right)$ & 2,60 & 2,90 & 2,92 \\
\hline
\end{tabular}

Os agregados graúdos, natural e reciclado, foram submetidos a ensaios para determinação da absorção, índices de vazios e massa específica no estado seco e saturado superfície seca, segundo a norma NBR 9937/87 "Agregados Determinação da Absorção e da Massa Específica de Agregado Graúdo”.

Este ensaio consiste em se lavar uma quantidade de amostra retida na peneira $4,8 \mathrm{~mm}$ e secá-la em estufa até constância de massa. Imerge-se o agregado em água, à temperatura ambiente, por \pm 24 horas. Retira-se a amostra da água enxugando-a cuidadosamente com pano absorvente e em seguida determina-se a massa da amostra na condição saturada com superfície seca ( B ).

Imediatamente após, coloca-se o material num cesto de arame com abertura de $3,4 \mathrm{~mm}$ ou menor, imergindo-o completamente num tanque com água, acoplando o cesto à uma balança fazendo a leitura na sua escala ( C ). A amostra é seca novamente em estufa até constância de massa, e a massa do agregado seco é determinada ( A ).

Utilizou-se as quantidades de $2 \mathrm{~kg}$ e $3 \mathrm{~kg}$ para agregados com $D_{\text {máx }}=9,5 \mathrm{~mm}$ e $\mathrm{D}_{\text {máx }}=19,0 \mathrm{~mm}$, respectivamente. Os valores obtidos são: 


$$
\gamma_{\mathrm{s}}=\frac{\mathrm{A}}{\mathrm{B}-\mathrm{C}} \quad \gamma_{\mathrm{sss}}=\frac{\mathrm{B}}{\mathrm{B}-\mathrm{C}} \quad \mathrm{a}=\frac{(\mathrm{B}-\mathrm{A})}{\mathrm{A}} \times 100
$$

onde:

$\gamma_{\mathrm{s}}=$ massa específica da amostra seca $\left(\mathrm{kg} / \mathrm{dm}^{3}\right)$

$\gamma_{\mathrm{sss}}=$ massa específica da amostra saturada com superfície seca $\left(\mathrm{kg} / \mathrm{dm}^{3}\right)$

$\mathrm{a}=$ absorção do agregado $(\%)$

$\mathrm{A}=$ massa do agregado seco $(\mathrm{kg})$

$\mathrm{B}=$ massa do agregado saturado com superfície seca $(\mathrm{kg})$

$\mathrm{C}=$ leitura correspondente ao agregado imerso em água $(\mathrm{kg})$

Os resultados podem ser vistos na Tabela 4.11 apresentada a seguir:

Tabela 4.11 - Absorção, índice de vazios e massa específica dos agregados

\begin{tabular}{ccccc}
\hline $\begin{array}{c}\text { tipo de } \\
\text { agregado }\end{array}$ & $\begin{array}{c}\text { absorção } \\
(\%)\end{array}$ & $\begin{array}{c}\text { índice de } \\
\text { vazios } \\
(\%)\end{array}$ & $\begin{array}{c}\gamma_{\mathrm{s}} \\
\left(\mathrm{kg} / \mathrm{dm}^{3}\right)\end{array}$ & $\begin{array}{c}\gamma_{\text {sss }} \\
\left(\mathrm{kg} / \mathrm{dm}^{3}\right)\end{array}$ \\
\hline natural (basalto) & $2,3(1,00)$ & $6,5(1,00)$ & $2,82(1,00)$ & $2,88(1,00)$ \\
\hline $\begin{array}{c}\text { reciclado } \\
\mathrm{D}_{\text {máx }}=19,0 \mathrm{~mm}\end{array}$ & $8,2(3,56)$ & $17,6(2,71)$ & $2,15(0,76)$ & $2,32(0,81)$ \\
\hline $\begin{array}{c}\text { reciclado } \\
\mathrm{D}_{\text {máx }}=9,5 \mathrm{~mm}\end{array}$ & $8,7(3,80)$ & $18,9(2,90)$ & $2,17(0,77)$ & $2,36(0,82)$ \\
\hline
\end{tabular}

Pelos resultados obtidos observa-se que, o fato de haver a necessidade, durante o preparo do concreto para moldagem dos corpos-de-prova, de se acrescentar mais água à mistura, pôde ser verificado através destes ensaios, devido ao índice de vazios do agregado reciclado ser quase 3 vezes superior ao valor do agregado natural, como pode ser visto na tabela acima. Devido à sua alta porcentagem de vazios, a absorção de água dos agregados reciclados também apresentou valores bem maiores (quase 4 vezes) do que para os agregados naturais.

No capítulo seguinte são apresentados os estudos efetuados para avaliar a influência do material reciclado no concreto fresco e endurecido e comentários são tecidos. 


\section{INFLUÊNCIA DO AGREGADO GRAÚDO RECICLADO NA PERDA DO ABATIMENTO DO CONCRETO FRESCO E NAS PROPRIEDADES MECÂNICAS DO CONCRETO ENDURECIDO}

Objetivando enriquecer os estudos até aqui conduzidos, estes ensaios foram realizados a fim de se investigar a influência do agregado graúdo reciclado, proveniente do entulho de construção e demolição, nas propriedades físicas e mecânicas do concreto fresco e endurecido.

Os ensaios foram conduzidos para dois tipos de graduações de agregados, uma com $D_{\text {máx }}$ igual a $19,0 \mathrm{~mm}$ e outro com $D_{\text {máx }}$ igual a $9,5 \mathrm{~mm}$. Os concretos foram preparados com as mesmas proporções até agora adotadas, isto é, com $50 \%$ e $100 \%$ de agregado graúdo reciclado em substituição ao agregado graúdo natural. Os ensaios realizados foram: perda de abatimento, massa específica no estado fresco, resistência à compressão (com determinação do módulo de elasticidade), resistência à tração na flexão e por compressão diametral. Verificou-se também a resistência à abrasão em função da relação direta existente entre esta e a dureza superficial do concreto. 


\subsection{Materiais Utilizados}

Os agregados naturais, miúdo e graúdo, utilizados nesta fase foram os mesmos empregados nas fases anteriores, provenientes da região de São Carlos. As características físicas foram determinadas conforme ensaios descritos no item 4.4.3 de acordo com as normas NBR 7251/82, NBR 7810/83 e NBR 9776/87 e os resultados já foram apresentados (Tabela 4.10).

O material graúdo reciclado utilizado para a confecção dos concretos foi o proveniente da amostra de entulho coletada em abril de 1997, cuja curva granulométrica e caracterização da natureza da composição estão apresentadas no item 4.4.1 e 4.4.2. A graduação dos agregados utilizados foi aquela caracterizada como brita 0 e brita 1 da NBR 7211/83. A determinação das características físicas destes agregados, para cada uma das graduações, foi realizada segundo os ensaios normatizados e apresentados na Tabela 4.9. O tipo de cimento utilizado para estes ensaios foi o CP II F-32.

\subsection{Concreto no Estado Fresco}

Nos ensaios anteriormente realizados, para a verificação da resistência (item 4.3.3), constatou-se que a simples substituição, em massa, dos agregados graúdos naturais pelos reciclados, apenas com pequeno acréscimo na quantidade de água de amassamento, resultava num concreto possível de ser moldado, porém com abatimento nulo em alguns casos (vide Tabela 4.8). A partir das misturas anteriormente preparadas, para a realização desta série de ensaios, todos os concretos, inclusive os de referência, foram ajustados para as seguintes finalidades: obter um abatimento de $60 \pm 10 \mathrm{~mm}$; usar um mesmo fator água/cimento; e alcançar um $\mathrm{f}_{\mathrm{ck}}=15 \mathrm{MPa}$ para o concreto de referência. As misturas foram feitas mecanicamente devido aos maiores volumes necessários à moldagem dos corpos-de-provas. As quantidades de materiais para cada faixa de agregado, medidas em massa, por metro cúbico de concreto fresco, estão apresentadas na Tabela 5.1: 
Tabela 5.1 - Quantidade de materiais utilizada em cada concreto

\begin{tabular}{|c|c|c|c|c|c|}
\hline \multirow[b]{2}{*}{$\begin{array}{l}D_{\text {máx }} \\
(\mathrm{mm})\end{array}$} & \multirow[b]{2}{*}{$\begin{array}{l}\text { tipo de } \\
\text { agregado } \\
\text { graúdo } \\
\end{array}$} & \multicolumn{4}{|c|}{ Quantidades de Materiais } \\
\hline & & $\begin{array}{c}\text { cimento } \\
\text { CP II F-32 } \\
\left(\mathrm{kg} / \mathrm{m}^{3}\right) \\
\end{array}$ & $\begin{array}{l}\text { areia natural } \\
\qquad\left(\mathrm{kg} / \mathrm{m}^{3}\right)\end{array}$ & $\begin{array}{l}\text { agregado } \\
\text { graúdo } \\
\left(\mathrm{kg} / \mathrm{m}^{3}\right) \\
\end{array}$ & $\begin{array}{c}\text { água } \\
\left(\mathrm{kg} / \mathrm{m}^{3}\right)\end{array}$ \\
\hline \multirow{4}{*}{19,0} & natural & 318 & 789 & 1.100 & 210 \\
\hline & $50 \%$ natural + & 318 & 722 & 1.008 & 226 \\
\hline & $50 \%$ reciclado & & & & \\
\hline & $100 \%$ reciclado & 347 & 652 & 909 & 239 \\
\hline \multirow{4}{*}{9,5} & natural & 358 & 909 & 755 & 269 \\
\hline & $50 \%$ natural + & 360 & 882 & 734 & 266 \\
\hline & $50 \%$ reciclado & & & & \\
\hline & $100 \%$ reciclado & 344 & 843 & 702 & 261 \\
\hline
\end{tabular}

\subsubsection{Ensaio de Perda do Abatimento}

Sabe-se que o agregado reciclado é mais poroso que o agregado natural e que o concreto recém-misturado enrijece com o tempo. Este fenômeno se dá devido a principalmente 3 fatores: uma parcela da água é perdida por evaporação; outra é removida por causa das reações químicas com o cimento e uma $3^{\text {a }}$ parcela da água da mistura é absorvida pelo agregado. Estes fatores afetam a trabalhabilidade do concreto fresco e têm influência significativa em suas características.

A fim de se obter parâmetros para definir qual o efeito e influência deste fenômeno no concreto, com a presença de agregado reciclado, realizou-se ensaio de perda de abatimento conforme as prescrições da NBR 10.342/88 "Concreto Fresco - Perda de Abatimento".

Inicialmente registra-se a temperatura ambiente, da água e do cimento. É necessário também marcar a hora no instante da adição da água na mistura. Determina-se o abatimento anotando-se a temperatura do concreto e a umidade relativa do ar e a hora correspondente. Subsequentemente são feitas medidas a cada 15 minutos até se chegar a valores de $30 \pm 10 \mathrm{~mm}$, quando se encerra o ensaio. 
No caso do presente trabalho, os ensaios foram conduzidos até um abatimento de $20 \pm 10 \mathrm{~mm}$, com o objetivo de se obter maior número de pontos para se traçar as curvas.

Foi realizado este ensaio para cada tipo de mistura de concreto contendo agregado natural, $100 \%$ de agregado graúdo reciclado e $50 \%$ de material reciclado e natural. Os resultados estão apresentados graficamente, como tempo decorrido contra porcentagem de perda de abatimento em relação à primeira leitura. São apresentados os resultados individuais para cada tipo de concreto e cada graduação do agregado, e por fim é apresentado a comparação entre as curvas, Figura $5 \cdot 1\left(D_{\text {máx }}=19,0 \mathrm{~mm}\right)$ e Figura $5.2\left(D_{\text {máx }}=9,5 \mathrm{~mm}\right)$ :
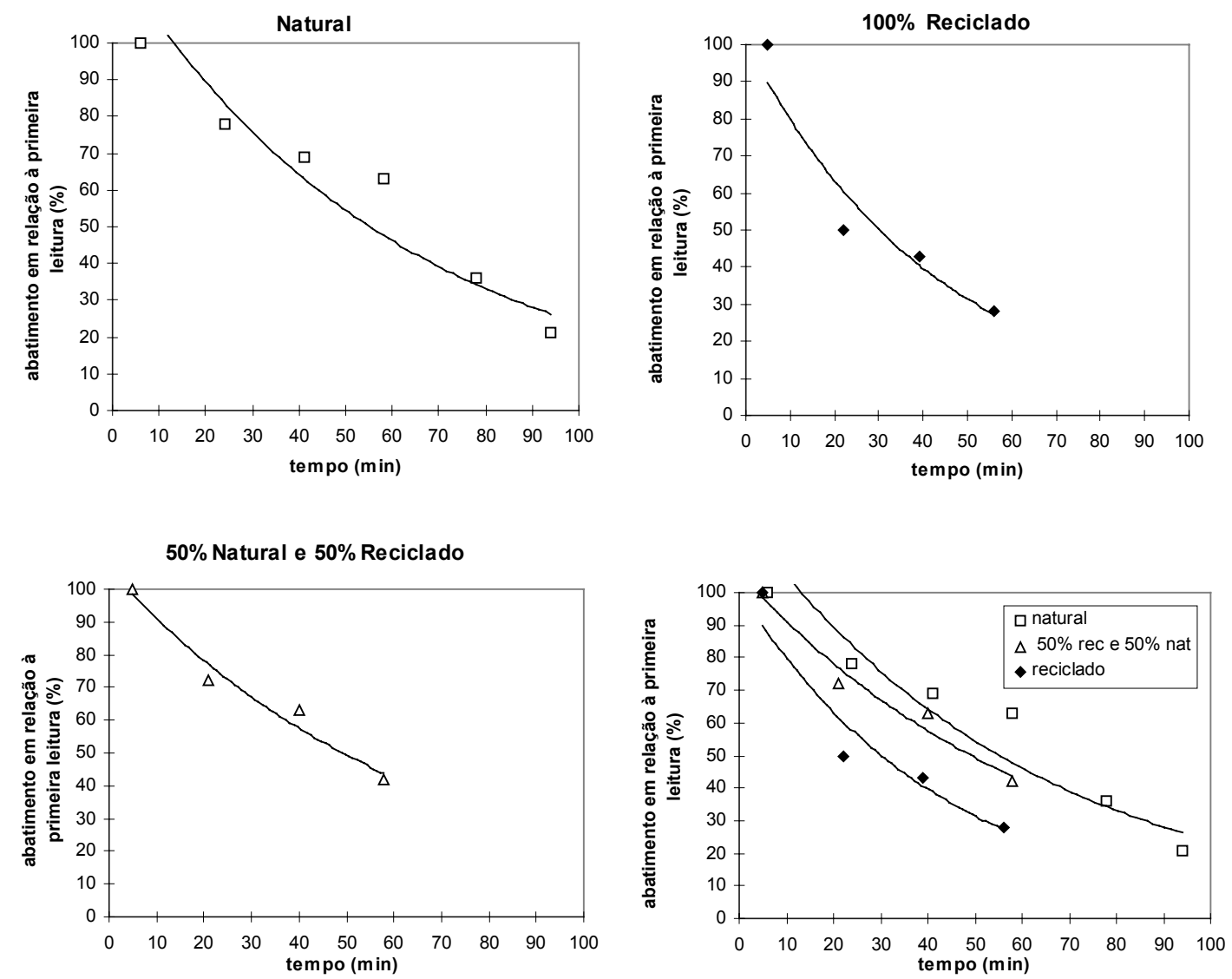

Figura 5.1 - Curvas de perda do abatimento individuais e comparação entre as curvas. Concretos com agregados graúdos com graduação $9,5 \mathrm{~mm}<D<19,0 \mathrm{~mm}$ 

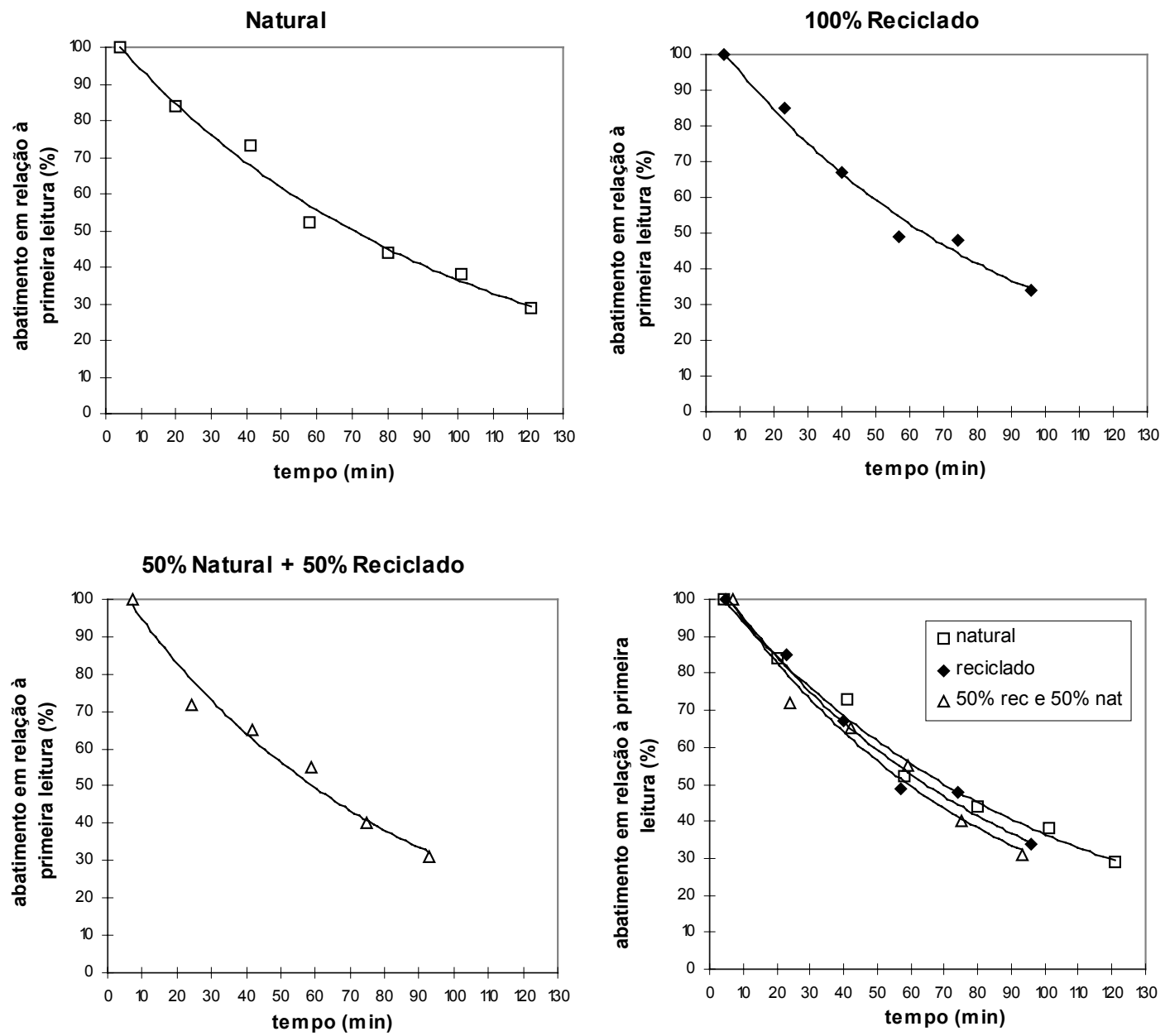

Figura 5.2 - Curvas de perda do abatimento individuais e comparação entre as curvas. Concretos com agregados graúdos com graduação $4,8 \mathrm{~mm}<\mathrm{D}<9,5 \mathrm{~mm}$

Como pode ser visto nas curvas individuais de perda de abatimento, para os concretos com agregados graúdos reciclados com $\mathrm{D}_{\text {máx }} 19,0 \mathrm{~mm}$ a inclinação das curvas foi bem mais acentuada, o que indica uma perda de abatimento mais rápida. Para o concreto de referência, o tempo de ensaio estendeu-se até 94 minutos após a adição da água, encerrando-se com um abatimento de 15 $\mathrm{mm}$ - representando $21 \%$ do abatimento inicial. Para os concretos com substituição de $50 \%$ e $100 \%$ de agregado graúdo reciclado, o ensaio estendeuse por 58 e 56 minutos, respectivamente, após a adição da água, obtendo-se um abatimento final de $18 \mathrm{~mm}$ e $11 \mathrm{~mm}$ - representando, para cada mistura, 42 e $28 \%$ da leitura do primeiro abatimento. 
Observando-se o gráfico comparativo entre os três concretos pode-se perceber que, tomando-se como referência o tempo de 58 minutos após a adição da água, o concreto com agregado natural apresentou abatimento de 63\% do valor inicial, o concreto com $100 \%$ de agregado graúdo reciclado teve um abatimento igual a $28 \%$ do inicial e o concreto com $50 \%$ de substituição resultou num abatimento aproximadamente médio entre os anteriores, chegando a $42 \%$ do primeiro abatimento medido.

As curvas para os concretos com $\mathrm{D}_{\text {máx }}=9,5 \mathrm{~mm}$, mesmo apresentando inclinações mais acentuadas (o que representa uma perda de abatimento mais rápida), mantiveram-se muito próximas umas das outras e inclusive do concreto de referência. Isto denota uma tendência à similaridade de comportamento entre os concretos. O ensaio foi encerrado ao se obter um abatimento de $18 \mathrm{~mm}$ para o concreto de referência, o que ocorreu após 121 minutos da adição da água de amassamento. Após 96 minutos da adição de água obteve-se um abatimento de $21 \mathrm{~mm}$ para o concreto com $100 \%$ de material graúdo reciclado. O concreto com $50 \%$ de substituição de reciclados apresentou um abatimento de $20 \mathrm{~mm}$ após 93 minutos da adição de água. Estes valores representam, respectivamente, $29 \%$, 34\% e $31 \%$ da primeira leitura de cada mistura.

Observando-se as curvas no gráfico comparativo e tomando-se como referência o tempo próximo aos 100 minutos, o abatimento representou 38\% do valor inicial para o concreto de referência contra $34 \%$ e $31 \%$ para os outros dois concretos.

Em ambos os tipos de agregado, o ensaio realizado com o material natural estendeu-se por mais tempo do que os demais, demonstrando maior demora para ocorrer a perda do abatimento. Em contrapartida, como se pode observar nos gráficos comparativos, os concretos confeccionados com substituição total ou parcial do agregado natural por material reciclado, apresentaram menor tempo de ensaio, demonstrando claramente a influência da maior absorção de água pelo agregado reciclado no concreto fresco. Este comportamento se assemelha ao observado nos concretos confeccionados com agregados graúdos leves. 


\subsubsection{Massa Específica do Concreto Fresco}

A massa específica do concreto fresco é definida como sendo a massa de um volume unitário de concreto fresco adensado, no qual se considera o volume de ar aprisionado ou incorporado. Esta quantidade de ar aprisionado, expressa em porcentagem do volume total de concreto fresco adensado, é denominada Teor de Ar ( NBR 9833/87).

O ensaio é realizado num recipiente cilíndrico, rígido e de metal sendo que, para agregados com diâmetros compreendidos entre $4,8 \mathrm{~mm}$ e $12,5 \mathrm{~mm}$, o recipiente possui capacidade para 3 litros, diâmetro nominal de $150 \mathrm{~mm}$ e altura interna de $170 \mathrm{~mm}$; e para agregados com diâmetros compreendidos entre $12,5 \mathrm{~mm}$ e $38 \mathrm{~mm}$, o recipiente apresenta diâmetro nominal de $250 \mathrm{~mm}$ e altura interna de $306 \mathrm{~mm}$, com capacidade para 15 litros.

Os recipientes são preenchidos em camadas aproximadamente iguais sendo que para o recipiente de 3 litros é necessário apenas uma camada fazendo-se o adensamento mecânico vibratório, e para o recipiente de 15 litros são necessárias 2 camadas de preenchimento com mesmo tipo de adensamento.

O tipo de adensamento é estabelecido de forma a que seja compatível com a consistência do concreto determinada através do ensaio de abatimento de tronco de cone, e em ambos os casos, para abatimento maior que $20 \mathrm{~mm}$, utilizou-se adensamento vibratório, conforme prescreve a norma. Finalmente, faz-se o rasamento e limpa-se a superfície do recipiente que é pesado e sua massa determinada. Apresenta-se na Tabela 5.2 os resultados obtidos: 
Tabela 5.2 - Massa específica do concreto fresco e condições ambiente durante o ensaio

\begin{tabular}{cccccc}
\hline $\begin{array}{c}\mathrm{D}_{\text {máx }} \\
(\mathrm{mm})\end{array}$ & $\begin{array}{c}\text { tipo de agregado } \\
\text { graúdo }\end{array}$ & $\begin{array}{c}\text { temperatura } \\
\text { ambiente } \\
\left({ }^{\circ} \mathrm{C}\right)\end{array}$ & $\begin{array}{c}\text { umidade } \\
\text { relativa } \\
(\%)\end{array}$ & $\begin{array}{c}\text { abatimento } \\
(\mathrm{mm})\end{array}$ & $\begin{array}{c}\text { massa } \\
\text { específica } \\
\left(\mathrm{kg} / \mathrm{dm}^{3}\right)\end{array}$ \\
\hline \multirow{3}{*}{19,0} & 31,1 & 54 & 75 & $2,442(1,00)$ \\
\cline { 2 - 7 } & $\begin{array}{c}50 \% \text { natural }+ \\
50 \% \text { reciclado }\end{array}$ & 31,5 & 60 & 80 & $2,323(0,95)$ \\
\cline { 2 - 7 } & $100 \%$ reciclado & 27,1 & 68 & 70 & $2,229(0,91)$ \\
\hline \multirow{3}{*}{9,5} & \begin{tabular}{l} 
natural \\
\cline { 2 - 7 }
\end{tabular} & 28,9 & 57 & 49 & $2,292(1,00)$ \\
\cline { 2 - 7 } & $50 \%$ natural + & 28,9 & 55 & 68 & $2,250(0,98)$ \\
\cline { 2 - 7 } & $100 \%$ reciciado & 29,1 & 54 & 75 & $2,192(0,96)$ \\
\hline
\end{tabular}

A massa específica do concreto contendo $100 \%$ de agregado graúdo reciclado está situada próxima ao limite superior dos concretos leves e ao limite inferior dos concretos normais. NEVILLE (1997) sugere que a massa específica no estado fresco pode ser uma boa aproximação para o cálculo do peso próprio de concretos com agregados leves. Estabelecendo-se uma analogia com as massas específicas dos agregados leves, a indicação do autor possivelmente poderia ser estendida aos agregados reciclados.

Pode-se constatar a influência da menor densidade do agregado reciclado através da análise dos valores obtidos para a massa específica dos concretos no estado fresco: para as granulometrias de $D_{\text {máx }}=19,0 \mathrm{~mm}$ e $\mathrm{D}_{\text {máx }}=9,5 \mathrm{~mm}$, os concretos com $100 \%$ de agregados reciclados apresentaram massa específica $9 \%$ e $4 \%$ menores do que aquelas referente ao concreto com agregado natural. Para os concretos com 50\% de agregados reciclados, esses valores situaram-se na média dos outros dois, representando uma certa proporcionalidade nos valores das massas específicas, mesmo utilizando-se material reciclado. 


\subsection{Concreto no Estado Endurecido}

A fim de identificar a influência do material reciclado no comportamento mecânico do concreto endurecido, uma série de ensaios foram programados. Em corpos-de-prova cilíndricos de $10 \mathrm{~cm}$ de diâmetro por $20 \mathrm{~cm}$ de altura foram realizados ensaios de resistência à compressão axial, com determinação do módulo de elasticidade tangente, e resistência à tração por compressão diametral. Para a determinação do módulo de ruptura à flexão foram realizados ensaios em exemplares prismáticos com seção transversal de $15 \times 15$ $\mathrm{cm}^{2}$ e comprimento de $75 \mathrm{~cm}$.

A Tabela 5.3 apresenta, para cada tipo de ensaio, o número de exemplares relativos ao concreto de referência e aos concretos contendo agregados reciclados.

Tabela 5.3 - Número de exemplares para cada tipo de ensaio

\begin{tabular}{|c|c|c|c|c|c|c|}
\hline \multirow{3}{*}{$\begin{array}{l}\mathrm{D}_{\text {máx }} \\
(\mathrm{mm})\end{array}$} & \multirow{3}{*}{$\begin{array}{l}\text { tipo de } \\
\text { agregado } \\
\text { graúdo }\end{array}$} & \multicolumn{5}{|c|}{ Número de Exemplares por Tipo de Ensaio } \\
\hline & & \multicolumn{2}{|c|}{$\begin{array}{c}\text { compressão } \\
\text { axial }\end{array}$} & \multirow{2}{*}{$\begin{array}{c}\text { compressão } \\
\text { diametral } \\
28 \mathrm{~d}\end{array}$} & \multirow{2}{*}{$\begin{array}{l}\text { módulo de } \\
\text { ruptura à } \\
\text { flexão } \\
28 \mathrm{~d}\end{array}$} & \multirow{2}{*}{$\begin{array}{l}\text { módulo de } \\
\text { elasticidade } \\
28 \mathrm{~d}\end{array}$} \\
\hline & & $7 \mathrm{~d}$ & $28 \mathrm{~d}$ & & & \\
\hline \multirow{4}{*}{19,0} & natural & 3 & 3 & 3 & 3 & 3 \\
\hline & $50 \%$ natural + & 3 & 3 & 3 & 3 & 3 \\
\hline & $50 \%$ reciclado & & & & & \\
\hline & $100 \%$ reciclado & 2 & 3 & 3 & 3 & 3 \\
\hline \multirow{4}{*}{9,5} & natural & 2 & 3 & 3 & 2 & 3 \\
\hline & $50 \%$ natural + & 3 & 3 & 3 & 2 & 3 \\
\hline & $50 \%$ reciclado & & & & & \\
\hline & $100 \%$ reciclado & 3 & 3 & 3 & 2 & 3 \\
\hline
\end{tabular}

Os concretos foram misturados mecanicamente em betoneira de eixo inclinado sem umidecimento prévio dos agregados reciclados, que se encontravam secos ao ar. Foi adotada uma das técnicas comumente utilizada para misturar concretos, e que a mesma tanto para misturas com reciclados como para os concreto com agregados naturais. Após a adição de toda a água de amassamento, os concretos foram misturados por um período de 3 minutos. 
Todos os exemplares foram moldados sob as mesmas condições de temperatura ambiente e umidade relativa do ar. O adensamento foi mecânico, executado com o auxílio de vibrador de agulha, de acordo com o prescrito pela NBR 5738/84. Após permanecerem 24 horas nas formas, os corpos-de-prova foram desmoldados e mantidos imersos em água até a data da realização dos ensaios.

\subsubsection{Ensaios de Resistência à Compressão com Determinação do Módulo de Elasticidade}

Os ensaios de resistência à compressão foram conduzidos seguindo as prescrições da NBR 5739/80. Os seis tipos de concretos, três com agregados graúdos com $\mathrm{D}_{\text {máx }}=19,0 \mathrm{~mm}$ e três com $\mathrm{D}_{\text {máx }}=9,5 \mathrm{~mm}$, foram preparados conforme as proporções indicadas no plano de ensaio. Os valores médios dos resultados experimentais podem ser vistos na Tabela 5.4:

Tabela 5.4 - Resistência à compressão e módulo de elasticidade

\begin{tabular}{ccccc}
\hline \multirow{2}{*}{$\mathrm{D}_{\text {máx }}$} & $\begin{array}{c}\text { tipo de agregado } \\
\text { graúdo }\end{array}$ & \multicolumn{2}{c}{$\begin{array}{c}\text { resistência } \\
\text { à compressão } \\
(\mathrm{MPa})\end{array}$} & $\begin{array}{c}\text { módulo de } \\
\text { elasticidade } \\
(\mathrm{GPa})\end{array}$ \\
\cline { 2 - 5 } & & $7 \mathrm{~d}$ & $28 \mathrm{~d}$ & $28 \mathrm{~d}$ \\
\hline \multirow{3}{*}{19,0} & natural & 18,0 & $25,4(1,00)$ & $15,4(1,00)$ \\
\cline { 2 - 5 } & $\begin{array}{l}50 \% \text { natural }+ \\
50 \% \text { reciclado }\end{array}$ & 20,8 & $29,3(1,15)$ & $17,5(1,14)$ \\
\cline { 2 - 5 } & $100 \%$ reciclado & 22,4 & $30,3(1,19)$ & $15,2(0,99)$ \\
\hline \multirow{3}{*}{9,5} & natural & 16,0 & $24,7(1,00)$ & $13,1(1,00)$ \\
\cline { 2 - 5 } & $50 \%$ natural + & 21,3 & $29,2(1,18)$ & $12,8(0,98)$ \\
& $50 \%$ reciclado & & & $13,4(1,02)$ \\
\cline { 2 - 5 } & $100 \%$ reciclado & 21,0 & $29,0(1,17)$ & \\
\hline
\end{tabular}

Os concretos de referência com $\mathrm{D}_{\text {máx }}=19,0 \mathrm{~mm}$ e $\mathrm{D}_{\text {máx }}=9,5 \mathrm{~mm}$ atingiram a resistência prevista para o ensaio aos 28 dias. Entre os concretos com agregados reciclados, para as duas graduações, não houve diferença significativa nos valores de resistência. Entretanto, estes valores resultaram cerca de $15 \%$ a $19 \%$ superiores aos do concreto de referência. Isto pode ser 
decorrente da elevada absorção do agregado reciclado que, como constatado nos ensaios anteriores ${ }^{1,}$ acaba por absorver uma parcela do volume total da água de amassamento.

A água retida nos poros dos agregados não fica disponível para a reação de hidratação do cimento. Porém, na fase de endurecimento da pasta provavelmente a água contida no interior do agregado reciclado irá contribuir para o processo de hidratação como se fosse uma "cura úmida interna" estabelecendo-se uma correlação à afirmativa de NEVILLE (1997) referente aos agregados leves, cuja absorção é elevada.

Em relação ao módulo de elasticidade, observando-se a Tabela 5.4, praticamente não houve nenhuma variação entre os concretos de referência e aqueles com $100 \%$ de agregados reciclados. Este fato pode ser devido à penetração da pasta nos poros superficiais dos agregados reciclados, o que garante uma melhor interação entre pasta e agregado. O fenômeno de "cura úmida interna" pode também vir a favorecer a aderência entre a matriz de cimento e os agregados. Para a determinação do módulo de elasticidade utilizou-se dos equipamentos do Laboratório de Geotecnia da EESC-USP, com programas que fornecem diretamente os valores do módulo de elasticidade tangente (tomados a 50\% do valor máximo da tensão) e o gráfico Tensão $\times$ Deformação. A Figura 5.3 mostra os gráficos Tensão $\times$ Deformação para as 2 graduações de agregados utilizados:

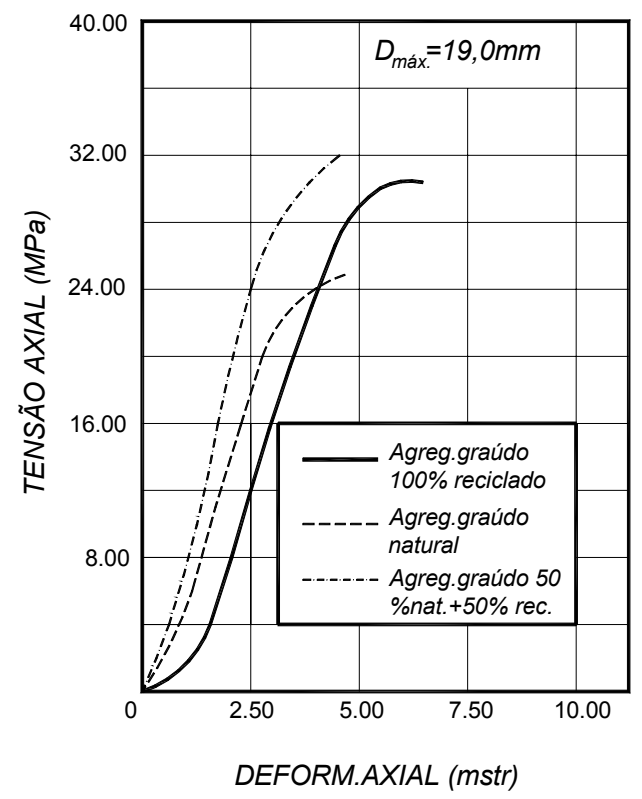

(a)

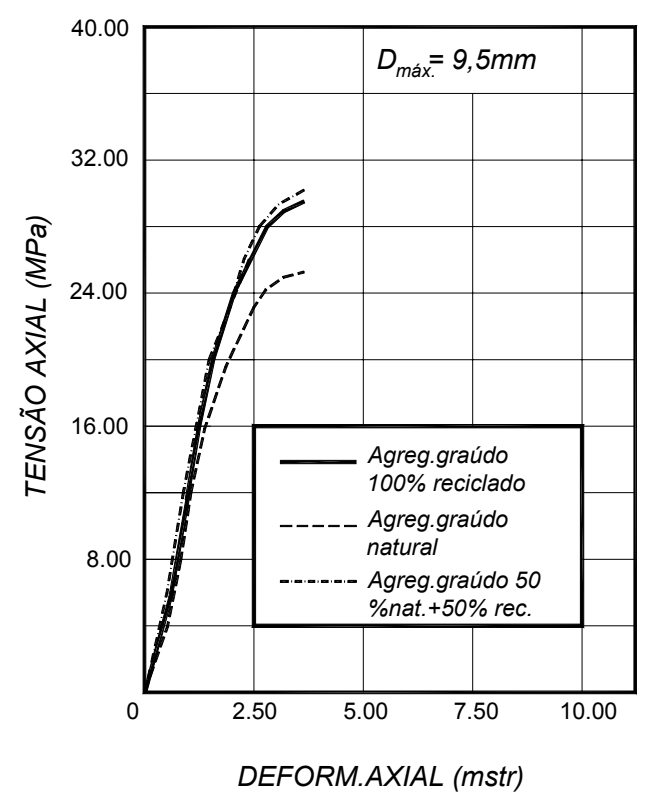

(b)

Figura 5.3 - Comparação entre gráficos Tensão $\times$ Deformação

\footnotetext{
${ }^{1}$ Vide Tabela 4.11 no item 4.4.3.
} 
No concreto contendo $50 \%$ de material reciclado, para a faixa de graduação com $\mathrm{D}_{\text {máx }}=19,0 \mathrm{~mm}$, o valor do módulo de elasticidade resultou $14 \%$ superior ao concreto de referência — fato que pode ser conferido observando-se a maior inclinação da curva tensão $\times$ deformação apresentada na Figura 5.10 a. Também pode-se notar nesta figura uma maior deformação conferida aos concretos contendo $100 \%$ de graúdos reciclados. Para os concretos com $\mathrm{D}_{\text {máx }}=9,5 \mathrm{~mm}$, o comportamento da fase elástica foi semelhante nos três casos, como pode ser visto na Figura 5.10 b:

\subsubsection{Ensaio de Resistência à Tração}

A resistência à tração no concreto pode ser obtida através dos seguinte ensaios: por tração direta, por compressão diametral ou por tração na flexão. RAPHAEL (1984) examinou o resultado de 12.000 (doze mil) exemplares a fim de encontrar a razão da dispersão entre os valores obtidos, propondo uma relação teórica entre resistência à tração e módulo de ruptura (tração na flexão). Da análise dos exemplares o autor discorre que pode haver respaldo para assumir uma relação direta (sem coeficiente de minoração) entre resistência à tração e compressão axial. Essas proposições serão tomadas como base também para avaliar o comportamento do concreto contendo agregado graúdo reciclado.

Para avaliar o desempenho à tração dos concretos com reciclados frente aos concretos convencionais de mesma classe, dois tipos de ensaios foram levados a efeito: ensaio de tração por compressão diametral em corpos-de-prova cilíndricos de $10 \mathrm{~cm}$ de diâmetro por $20 \mathrm{~cm}$ de altura, e ensaio de tração na flexão, conduzido em exemplares prismáticos de seção transversal de $15 \times 15$ $\mathrm{cm}^{2}$ e comprimento de $75 \mathrm{~cm}$. Nestes últimos, o carregamento é aplicado nos terços do vão.

A realização dos ensaios obedeceu as prescrições da norma NBR-7222/83 e do código da ASTM C 78-94.

Os valores médios dos resultados obtidos em ambos os ensaios, constam da Tabela 5.5. Um exemplar prismático preparado para o ensaio de flexão está ilustrado na Figura 5.4: 
Tabela 5.5 - Resistência à tração

\begin{tabular}{|c|c|c|c|}
\hline \multirow[b]{2}{*}{$\mathrm{D}_{\text {máx }}$} & \multirow{3}{*}{$\begin{array}{l}\text { tipo de } \\
\text { agregado } \\
\text { graúdo }\end{array}$} & \multicolumn{2}{|c|}{ Resistência à Tração } \\
\hline & & $\begin{array}{c}\text { por compressão } \\
\text { diametral } \\
(\mathrm{MPa})\end{array}$ & $\begin{array}{l}\text { na flexão } \\
(\mathrm{MPa})\end{array}$ \\
\hline$(\mathrm{mm})$ & & $28 \mathrm{~d}$ & $28 \mathrm{~d}$ \\
\hline \multirow{3}{*}{19,0} & natural & 2,6 & 3,7 \\
\hline & $\begin{array}{l}50 \% \text { natural }+ \\
50 \% \text { reciclado }\end{array}$ & 2,6 & 3,7 \\
\hline & $100 \%$ reciclado & 2,7 & 3,9 \\
\hline \multirow{3}{*}{9,5} & natural & 2,3 & 3,3 \\
\hline & $\begin{array}{l}50 \% \text { natural }+ \\
50 \% \text { reciclado }\end{array}$ & 2,5 & 3,4 \\
\hline & $100 \%$ reciclado & 2,2 & 3,3 \\
\hline
\end{tabular}

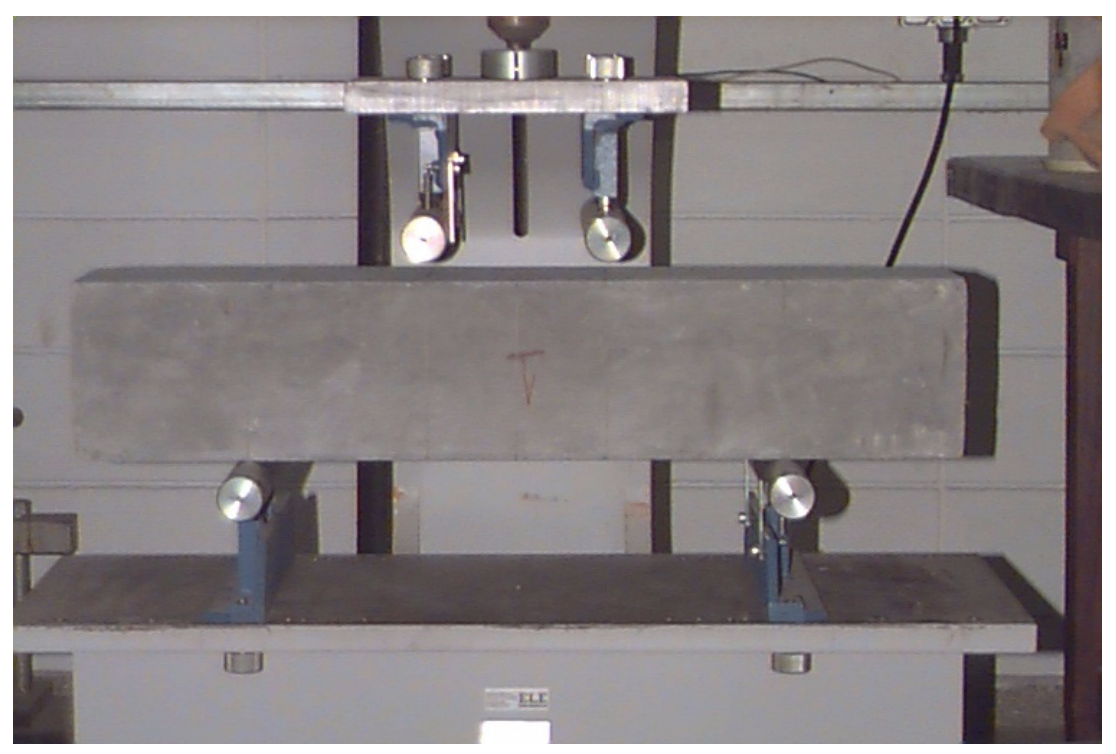

Figura 5.4: Aparato para ensaio à flexão

No ensaio por compressão diametral, a ruptura ocorre por tração horizontal através do fendilhamento segundo o plano vertical de carregamento - o que provoca o corte diametral do corpo-de-prova, também no plano vertical. Pela Teoria da Elasticidade Bi-dimensional, a expressão da resistência à tração horizontal é definida por: 


$$
\mathrm{f}_{\mathrm{t} D}=\frac{2 \cdot \mathrm{P}}{\pi \cdot \mathrm{D} \cdot \mathrm{L}}
$$

onde:

$$
\begin{array}{ll}
\mathrm{f}_{\mathrm{tD}} & =\text { resistência à tração por compressão diametral } \\
\mathrm{P} & =\text { força de ensaio } \\
\mathrm{L} & =\text { altura do corpo-de-prova } \\
\mathrm{D} & =\text { diâmetro do corpo-de-prova }
\end{array}
$$

No ensaio de flexão com carregamento nos terços do vão teórico, a resistência à tração máxima na face tracionada do corpo-de-prova é fornecida pela teoria elementar da flexão, e é conhecida como módulo de ruptura.

Para o cálculo do módulo de ruptura, no caso de a ruptura ocorrer no terço médio do vão, a ASTM C 78-94 prescreve a fórmula :

$$
f_{t F}=\frac{P \cdot L}{b \cdot d^{2}}
$$

Se a ruptura ocorrer fora do terço médio, a uma distância afastada não mais que $5 \%$ do vão, a norma fornece a seguinte expressão para o cálculo dessa grandeza:

$$
f_{t F}=\frac{3 \cdot P \cdot a}{b \cdot d^{2}}
$$

onde:

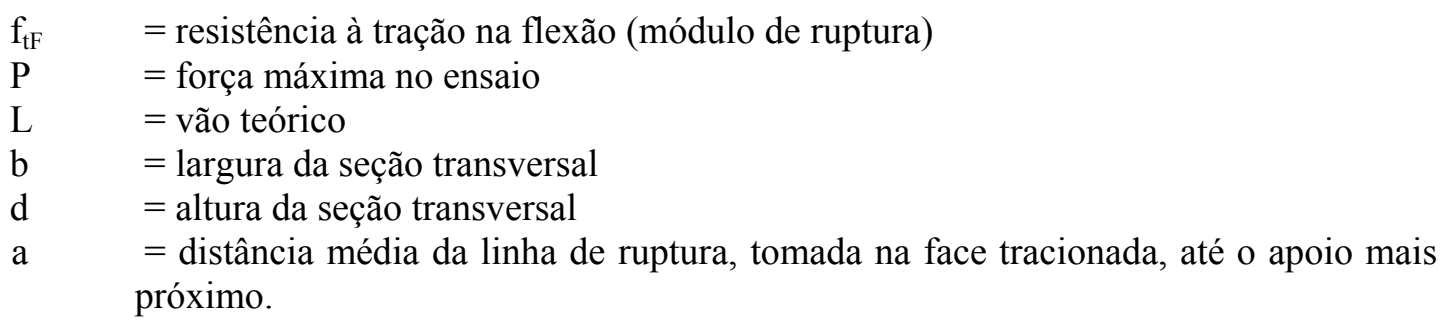

Pode-se perceber, analisando-se a Tabela 5.5, que a procedência do agregado graúdo (natural ou reciclado) não influenciou os resultados nos dois tipos de ensaio para ambas as graduações empregadas. Os concretos preparados com agregados reciclados obtiveram desempenho igual ou ligeiramente superior aos concretos de referência - como no caso de concreto com $100 \%$ de agregado reciclado, para $\mathrm{D}_{\text {máx }}=19,0 \mathrm{~mm}$ e de concreto com $50 \%$ de substituição para $D_{\text {máx }}=9,5 \mathrm{~mm}$. O fato do agregado reciclado apresentar desempenho à tração ligeiramente superior pode ser atribuído à boa aderência existente entre a pasta e o agregado - em virtude dos poros existentes neste último, como explicado anteriormente. Esta hipótese pode ser confirmada 
levando-se em conta que, durante os ensaios, tanto de tração por compressão diametral quanto de flexão, os planos de ruptura passavam pelos agregados.

As relações teóricas, baseadas em resultados de ensaios, entre resistência à tração direta $\left(\mathrm{f}_{\mathrm{tT}}\right)$ (considerada o valor real da tensão de tração no concreto), resistência à tração por compressão diametral $\left(\mathrm{f}_{\mathrm{tD}}\right)$, resistência à tração na flexão $\left(f_{\text {tF }}\right)$ e resistência à compressão $\left(f_{c}\right)$, encontradas por RAPHAEL (1994), como também encontradas na proposta de revisão da NB-1/78, comprovam que os concretos com agregados graúdos reciclados seguem as mesmas leis. Uma constatação gratificante, verificada durante a comparação entre os resultados experimentais e teóricos, é que a resistência à tração por compressão diametral, quando o ensaio é bem conduzido, pode representar, ela mesma, a resistência à tração do concreto. Primeiramente são apresentados na Tabela 5.6 os resultados obtidos experimentalmente junto com a proposição teórica de Raphael. Na seqüência, é mostrado a comparação entre esses valores, apenas para resistência à tração por compressão diametral, além da proposta da revisão da NB1/78, Tabela 5.7.

Tabela 5.6 - Relações entre valores teóricos e experimentais.

\begin{tabular}{|c|c|c|c|c|c|c|c|}
\hline \multirow[b]{2}{*}{$\mathrm{D}_{\text {máx }}$} & \multirow[b]{2}{*}{ Agregado } & \multicolumn{3}{|c|}{ EXPERIMENTAL } & \multicolumn{3}{|c|}{ TEÓRICO (Raphael) } \\
\hline & & $f_{c}$ & $f_{t D}$ & $\mathrm{f}_{\mathrm{tF}}$ & $\mathrm{f}_{\mathrm{tF}}=$ & $\mathrm{f}_{\mathrm{tT}}=$ & $\mathrm{f}_{\mathrm{tT}}=$ \\
\hline & & & & & $0,44 \mathrm{f}_{\mathrm{c}}^{2 / 3}$ & $0,33 \mathrm{f}_{\mathrm{c}}^{2 / 3}$ & $0,75 \mathrm{f}_{\mathrm{tF}}$ \\
\hline \multirow[t]{2}{*}{$(\mathrm{mm})$} & graúdo & ( MPa ) & ( MPa ) & ( MPa ) & ( MPa ) & $(\mathrm{MPa})$ & $(\mathrm{MPa})$ \\
\hline & natural & 25,4 & 2,6 & 3,7 & 3,8 & 2,8 & 2,8 \\
\hline \multirow[t]{3}{*}{19,0} & $\begin{array}{l}50 \% \text { natural }+ \\
50 \% \text { reciclado }\end{array}$ & 29,3 & 2,6 & 3,7 & 4,2 & 3,1 & 2,8 \\
\hline & $100 \%$ reciclado & 30,3 & 2,7 & 3,9 & 4,3 & 3,2 & 2,9 \\
\hline & natural & 24,7 & 2,3 & 3,3 & 3,7 & 2,8 & 2,5 \\
\hline \multirow[t]{2}{*}{9,5} & $\begin{array}{l}50 \% \text { natural }+ \\
50 \% \text { reciclado }\end{array}$ & 29,2 & 2,5 & 3,4 & 4,2 & 3,1 & 2,6 \\
\hline & $100 \%$ reciclado & 29,0 & 2,2 & 3,3 & 4,2 & 3,1 & 2,5 \\
\hline
\end{tabular}

onde:

$\mathrm{f}_{\mathrm{c}} \quad=$ resistência à compressão axial aos 28 dias

$\mathrm{f}_{\mathrm{tD}} \quad=$ resistência à tração por compressão diametral

$\mathrm{f}_{\mathrm{tF}} \quad=$ resistência à tração na flexão (módulo de ruptura)

$\mathrm{f}_{\mathrm{t}}=$ resistência à tração direta 
Tabela 5.7 - Resistência à tração aos 28 dias - Comparação entre os valores experimentais de resistência à tração por compressão diametral, RAPHAEL e proposta da revisão da NB-1/78

\begin{tabular}{|c|c|c|c|c|c|c|}
\hline & \multicolumn{6}{|c|}{ Valores de Resistência à Tração } \\
\hline \multirow{4}{*}{$\begin{array}{c}\text { Tipos } \\
\text { de } \\
\text { concreto }\end{array}$} & EXPERI- & \multicolumn{5}{|c|}{ TEÓRICO } \\
\hline & compressão & \multicolumn{2}{|c|}{ Raphael } & \multicolumn{3}{|c|}{ Revisão da NB - 1/78 } \\
\hline & $\mathrm{f}_{\mathrm{tD}}$ & $\begin{array}{c}\mathrm{f}_{\mathrm{tT}}= \\
0,75 \mathrm{f}_{\mathrm{tF}}\end{array}$ & $\begin{array}{c}\mathrm{f}_{\mathrm{tT}}= \\
0,33 \mathrm{f}_{\mathrm{c}}{ }^{2 / 3}\end{array}$ & $\begin{array}{c}\mathrm{f}_{\mathrm{tT}}= \\
0,9 \mathrm{f}_{\mathrm{tD}}\end{array}$ & $\begin{array}{c}\mathrm{f}_{\mathrm{tT}}= \\
0,7 \mathrm{f}_{\mathrm{tF}}\end{array}$ & $\begin{array}{c}\mathrm{f}_{\mathrm{tT}}= \\
0,3 \mathrm{f}_{\mathrm{c}}{ }^{2 / 3}\end{array}$ \\
\hline & $(\mathrm{MPa})$ & $(\mathrm{MPa})$ & $(\mathrm{MPa})$ & $(\mathrm{MPa})$ & $(\mathrm{MPa})$ & $(\mathrm{MPa})$ \\
\hline natural & 2,6 & 2,8 & 2,8 & 2,3 & 2,6 & 2,6 \\
\hline $\begin{array}{l}50 \% \text { natural }+ \\
50 \% \text { reciclado }\end{array}$ & 2,6 & 2,8 & 3,1 & 2,3 & 2,6 & 2,9 \\
\hline $100 \%$ reciclado & 2,7 & 2,9 & 3,2 & 2,4 & 2,7 & 2,9 \\
\hline natural & 2,3 & 2,5 & 2,8 & 2,1 & 2,3 & 2,5 \\
\hline $\begin{array}{l}50 \% \text { natural }+ \\
50 \% \text { reciclado }\end{array}$ & 2,5 & 2,6 & 3,1 & 2,3 & 2,4 & 2,8 \\
\hline $100 \%$ reciclado & 2,2 & 2,5 & 3,1 & 2,0 & 2,3 & 2,8 \\
\hline
\end{tabular}

Observa-se pela tabela que os valores de resistência à compressão diametral, obtidos experimentalmente, são praticamente idênticos aos propostos pela revisão da NB-1/78, tomando-se a resistência à tração direta em relação à resistência à tração na flexão (módulo de ruptura). Para melhor visualização, apresentamos esses valores nas Figuras 5.5 e 5.6, separadamente para as graduações $D_{\text {máx }}=19,0 \mathrm{~mm}$ e $D_{\text {máx }}=9,5 \mathrm{~mm}$, respectivamente.

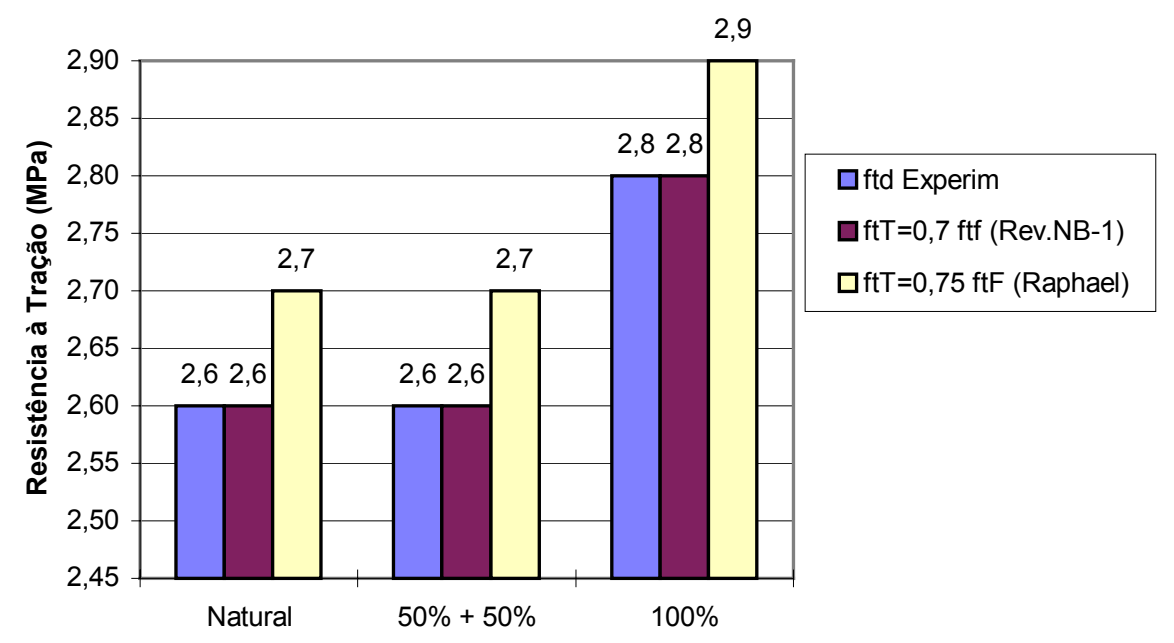

Figura 5.5: Gráfico comparativo de resistência à tração- $D_{\text {máx }}=19,0 \mathrm{~mm}$ 


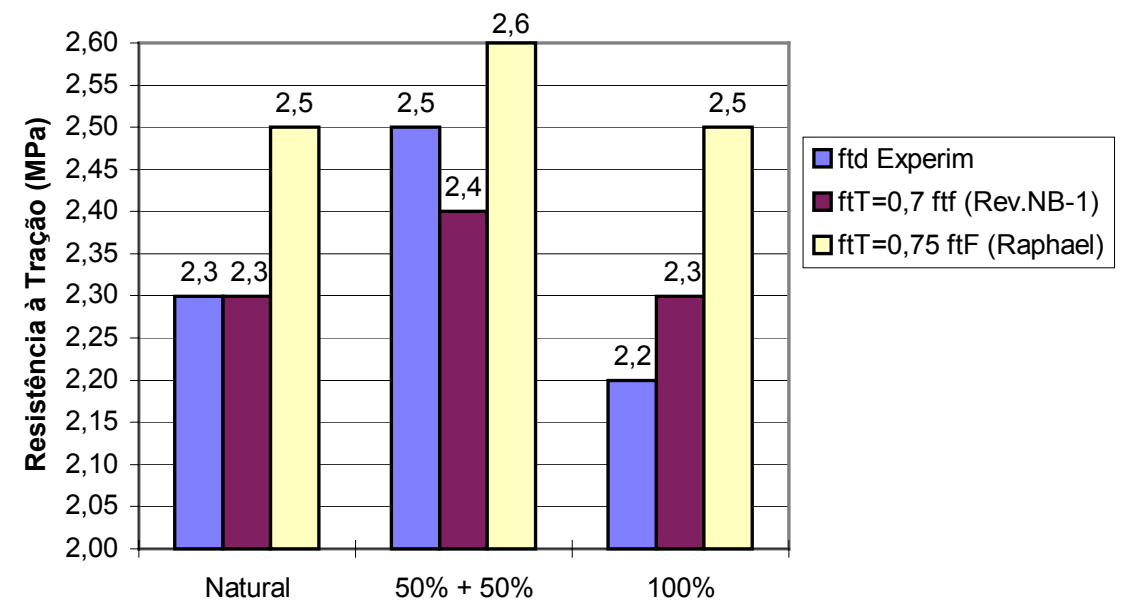

Figura 5.6: Gráfico comparativo de resistência à tração- $D_{\text {máx }}=9,5 \mathrm{~mm}$

A atual, e ainda em vigor, NB-1/78 estabelece uma relação de 0,85 entre os valores de resistência à tração direta e os obtidos por compressão diametral, para concretos. Mesmo propondo alteração deste coeficiente de 0,85 para 0,90 (vide Tabela 5.7), estes valores ainda se mantêm conservadores. A proposição da RILEM (1993), apresentada no capítulo 3 (Tabela 3.1-reproduzida aqui para simples visualização), propõe que a relação entre tração direta e tração por compressão diametral, mesmo que para concretos com agregados reciclados, seja diretamente proporcional (relação 1:1). Este fato pôde ser verificado e constatado pelos resultados obtidos, também para concretos que utilizaram agregados reciclados em suas misturas.

Tabela 3.1 - Coeficientes de relação

\begin{tabular}{|c|c|c|c|}
\hline Valores de Projeto & Tipo I & Tipo II & Tipo III \\
\hline resistência à tração & 1 & 1 & 1 \\
\hline módulo de elasticidade & 0,65 & 0,8 & 1 \\
\hline
\end{tabular}

\subsection{Resistência à Abrasão do Concreto com Agregado Graúdo Reciclado}

Uma forma de se verificar um dos fatores que influenciam a durabilidade em concretos, é avaliar a resistência à abrasão do mesmo. Sabendo-se que existe uma relação direta entre a resistência à abrasão e a dureza superficial do concreto, SADEGZADEH (1986), foram realizados ensaios de esclerometria, com finalidade apenas comparativa, nos concretos de referência e com 
material reciclado para as duas faixas de graduação dos agregados $\left(\mathrm{D}_{\operatorname{máx}}=\right.$ $19,0 \mathrm{~mm}$ e $\mathrm{D}_{\text {máx }}=9,5 \mathrm{~mm}$ ).

Para a execução dos ensaios, foram utilizados os prismas ensaiados anteriormente. Realizaram-se nove determinações esclerométricas nos concretos com $D_{\text {máx }}=19,0 \mathrm{~mm}$ e seis para os concretos com $\mathrm{D}_{\text {máx }}=9,5 \mathrm{~mm}$. A subdivisão para cada tipo de concreto, bem como os valores dos resultados obtidos com as respectivas datas de ensaios, estão apresentados na Tabela 5.8:

Tabela 5.8 - Valores dos índices esclerométricos

\begin{tabular}{|c|c|c|c|c|}
\hline $\begin{array}{l}\mathrm{D}_{\text {máx }} \\
(\mathrm{mm}) \\
\end{array}$ & $\begin{array}{c}\text { tipo de } \\
\text { agregado graúdo }\end{array}$ & $\begin{array}{l}\mathrm{n}^{\mathrm{o}} \text { do } \\
\text { prisma }\end{array}$ & $\begin{array}{l}\text { idade } \\
\text { (dias) } \\
\end{array}$ & $\begin{array}{c}\text { índice } \\
\text { esclerométrico } \\
\end{array}$ \\
\hline \multirow{9}{*}{19,0} & \multirow{3}{*}{ natural } & 1 & 44 & 25,5 \\
\hline & & 2 & 44 & 24,4 \\
\hline & & 3 & 44 & - \\
\hline & \multirow{3}{*}{$\begin{array}{l}50 \% \text { natural }+ \\
50 \% \text { reciclado }\end{array}$} & 4 & 43 & 28,6 \\
\hline & & 5 & 43 & 27,0 \\
\hline & & 6 & 43 & 27,3 \\
\hline & \multirow{3}{*}{$\begin{array}{l}100 \% \\
\text { reciclado }\end{array}$} & 7 & 43 & 25,8 \\
\hline & & 8 & 43 & 29,0 \\
\hline & & 9 & 43 & 26,8 \\
\hline \multirow{6}{*}{9,5} & \multirow[t]{2}{*}{ natural } & 1 & 29 & 18,9 \\
\hline & & 2 & 29 & 19,1 \\
\hline & \multirow{2}{*}{$\begin{array}{l}50 \% \text { natural }+ \\
50 \% \text { reciclado }\end{array}$} & 3 & 29 & 22,6 \\
\hline & & 4 & 29 & 22,8 \\
\hline & \multirow[b]{2}{*}{$100 \%$ reciclado } & 5 & 29 & 20,8 \\
\hline & & 6 & 29 & 20,6 \\
\hline
\end{tabular}

Como os ensaios tiveram finalidade apenas comparativa, a diferença nas idades de determinação entre as graduações dos agregados não comprometeu a avaliação dos resultados.

Os maiores valores obtidos para os índices esclerométricos determinados nos concretos com $\mathrm{D}_{\text {máx }}=19,0 \mathrm{~mm}$ certamente são devidos à diferença de duas semanas nas idades destes.

Observando-se a Tabela 5.8 e considerando-se cada grupo de agregados, verifica-se que há uma uniformidade nos valores, o que demonstra a homogeneidade do concreto nos exemplares ensaiados. Os valores mais altos dos índices esclerométricos dos concretos contendo agregados reciclados, obtidos neste estudo, correspondem à maior resistência à compressão dos 
mesmos e indicam que a dureza superficial, neste caso foi, no mínimo, igual à dos concretos de referência.

No capítulo 6, o material concreto contendo agregado reciclado é utilizado como uma aplicação na fabricação de painéis leves de vedação, apresentandose os fundamentos teóricos e as considerações de cálculo para a realização dos experimentos. 


\section{APLICAÇÃO DE CONCRETO COM AGREGADO RECICLADO NA FABRICAÇÃO DE PAINÉIS LEVES DE VEDAÇÃO}

A fim de dar uma aplicação prática aos estudos até agora conduzidos e, dados os bons resultados apresentados pelo material reciclado, nesta fase propôs-se um modelo de painel nervurado com o objetivo de se realizar ensaios para análise do desempenho à flexão dos painéis confeccionados com concreto utilizando-se agregado graúdo reciclado, comparando o seu desempenho frente a um painel de referência moldado com concreto confeccionado com agregados naturais.

O componente utilizado faz parte de um ante-projeto para confecção de painéis leves pré-moldados para construção de habitações populares, com várias tipologias definidas, no qual o Laboratório de Estruturas da EESC realizou alguns ensaios para avaliação do desempenho estrutural. Adotou-se, para avaliação do desempenho à flexão, a tipologia principal que caracterizase por apresentar a maior geometria entre as demais. As configurações construtivas para o posicionamento do painel em uma parede são apresentadas no item 6.4, onde se define as dimensões do componente escolhido.

Faz-se, entretanto, uma abordagem inicial sobre a Teoria Elementar da Flexão, a fim de fornecer os fundamentos utilizados na análise teórica dos painéis. Também é abordado o dimensionamento das peças para o estado limite último e são realizadas as verificações do momento fletor de fissuração no estado 
limite de utilização, bem como as verificações do estado de deformação excessiva.

Por fim é descrita a parte experimental dos ensaios à flexão realizados nos painéis e nos corpos-de-prova moldados com o mesmo concreto, com base na formulação teórica descrita e os resultados são apresentados no capítulo seguinte.

\subsection{Teoria Elementar da Flexão}

Os ensaios foram conduzidos em peças do tipo painéis nervurados, porém por simplificação, estes foram considerados, para efeito da análise teórica, como se fossem vigas submetidas a um carregamento uniforme.

Utilizando-se o Princípio dos Trabalhos Virtuais (PTV), pode-se determinar o deslocamento $\delta$ no meio do vão de uma viga, para um dado estado de deslocamento, tomando-se como estado de forças um carga unitária no meio da viga. Logo, aplicando-se o PTV tem-se:

$$
\delta=\int \mathrm{Md} \phi
$$

onde:

$$
d \phi=\frac{\overline{\mathrm{M}}}{\mathrm{EI}} d x
$$

sendo,

$$
\begin{array}{ll}
\overline{\mathrm{M}} & =\text { momento fletor devido à ação atuante na viga; } \\
\mathrm{M} & =\text { momento devido a uma força unitária no meio do vão; } \\
\mathrm{EI} & =\text { rigidez à flexão da viga; }
\end{array}
$$

para o estado de deslocamento dado. Substituindo-se a Equação 6.2 em 6.1 tem-se:

$$
\delta=\int_{\text {estrut. }} \mathrm{M}\left(\frac{\overline{\mathrm{M}}}{\mathrm{EI}}\right) \mathrm{dx}
$$


Através da equação 6.3, dado o estado de deslocamento, pode-se facilmente determinar os deslocamentos no meio do vão da viga. A seguir são dadas as expressões finais do deslocamento no meio do vão para uma viga simplesmente apoiada, de comprimento L com carga uniformemente distribuída, e também com carga concentrada aplicada nos terços do vão da mesma:

- Viga com carregamento uniformemente distribuído $q$ ao longo do comprimento L do vão. Para o deslocamento tem-se:

$$
\delta=\frac{5 q L^{4}}{384 E I}
$$

- Viga com carregamento concentrado F/2 aplicado nos terços do vão teórico. Para o deslocamento tem-se:

$$
\delta=\frac{23 F L^{3}}{1.296 E I}
$$

\subsection{Dimensionamento dos Painéis}

Inicialmente é preciso avaliar a magnitude dos esforços, tomando-se a distribuição de cargas com base no critério elástico. No dimensionamento dos painéis nervurados foi utilizada a teoria usual do concreto armado, considerando-se a seção transversal de maneira simplificada com relação à sua geometria.

A armadura longitudinal para a região mais solicitada (meio do vão), foi calculado no estado limite último para o momento fletor característico $\left(\mathrm{M}_{\mathrm{k}}\right)$ atuante na estrutura, para efeito de comparação com os valores obtidos experimentalmente nos ensaios de flexão.

O Estado Limite Último é definido pela norma brasileira como sendo o estado correspondente à ruína da peça, seja por ruptura do concreto, por deformação plástica excessiva da armadura ou por instabilidade. As hipóteses de cálculo utilizadas foram as prescritas pela NBR 6118/78 "Projeto e Execução de Obras de Concreto Armado". 
Para o Estado Limite de Utilização, são feitas as verificações considerando-se os carregamentos, ou seja, as solicitações de serviço, previstos para o uso normal de peças do tipo das estudadas neste trabalho. As hipóteses de cálculo utilizadas são as mesmas adotadas para peças fletidas de concreto armado prescritas pela NBR 6118/78.

\subsubsection{Momento Fletor de Fissuração $\left(M_{r}\right)$}

Para verificação do momento fletor de fissuração, considerou-se, da mesma maneira, as hipóteses de cálculo da NBR 6118, supondo o comportamento do material como sendo elástico. Este momento é definido como sendo o valor que ocorre no limite entre o estádio I e II, ou seja, no estádio Ib.

O efeito da retração neste caso deve ser sempre levado em consideração e, para efeito de simplificação, nas condições correntes, este efeito pode ser considerado supondo-se a tensão de tração igual a $0,75 \mathrm{f}_{\mathrm{tk}}$ e desprezando-se a armadura. $\mathrm{O}$ valor de $\mathrm{f}_{\mathrm{tk}}$ teórico de projeto pode ser calculado pelas expressões (NBR 6118/78):

$$
\begin{array}{lll}
\mathrm{f}_{\mathrm{tk}}=\frac{\mathrm{f}_{\mathrm{ck}}}{10} & \text { para } \mathrm{f}_{\mathrm{ck}} \leq 18 \mathrm{MPa} & \text { Eq. } 6.6 \\
\mathrm{f}_{\mathrm{tk}}=0,06 \cdot \mathrm{f}_{\mathrm{ck}}+0,7 & \text { para } \mathrm{f}_{\mathrm{ck}}>18 \mathrm{MPa} & \text { Eq. } 6.7
\end{array}
$$

Observadas as indicações da norma, a deformação de ruptura à tração do concreto $\left(\varepsilon_{\mathrm{cr}}\right)$, vale:

$$
\varepsilon_{c r}=1,5 \cdot 2,7 \cdot 0,75 \cdot \frac{\mathrm{f}_{\mathrm{tk}}}{\mathrm{E}_{\mathrm{c}}}
$$

onde,

$$
\boldsymbol{E}_{c \mathrm{sec}}=0,85 \cdot 6.600 \sqrt{\boldsymbol{f}_{\boldsymbol{c}}+3,5}(\mathrm{em} \mathrm{MPa})
$$

Com essas hipóteses montam-se as equações de equilíbrio e compatibilidade de deformações que, convenientemente arranjadas e desenvolvidas fornecem a posição da linha neutra ( $x$ ) e o valor do momento fletor de fissuração $\left(M_{r}\right)$. Com base na Figura 6.1 e nas expressões 6.11 a 6.13 obtém-se a seguinte expressão:

$$
\frac{b_{f} \cdot \sigma_{c}}{2} \cdot x=\sigma_{c t} \cdot b_{f} \cdot\left(h-x-h_{f}\right)+\sigma_{c t} \cdot h_{f} \cdot b_{w}
$$



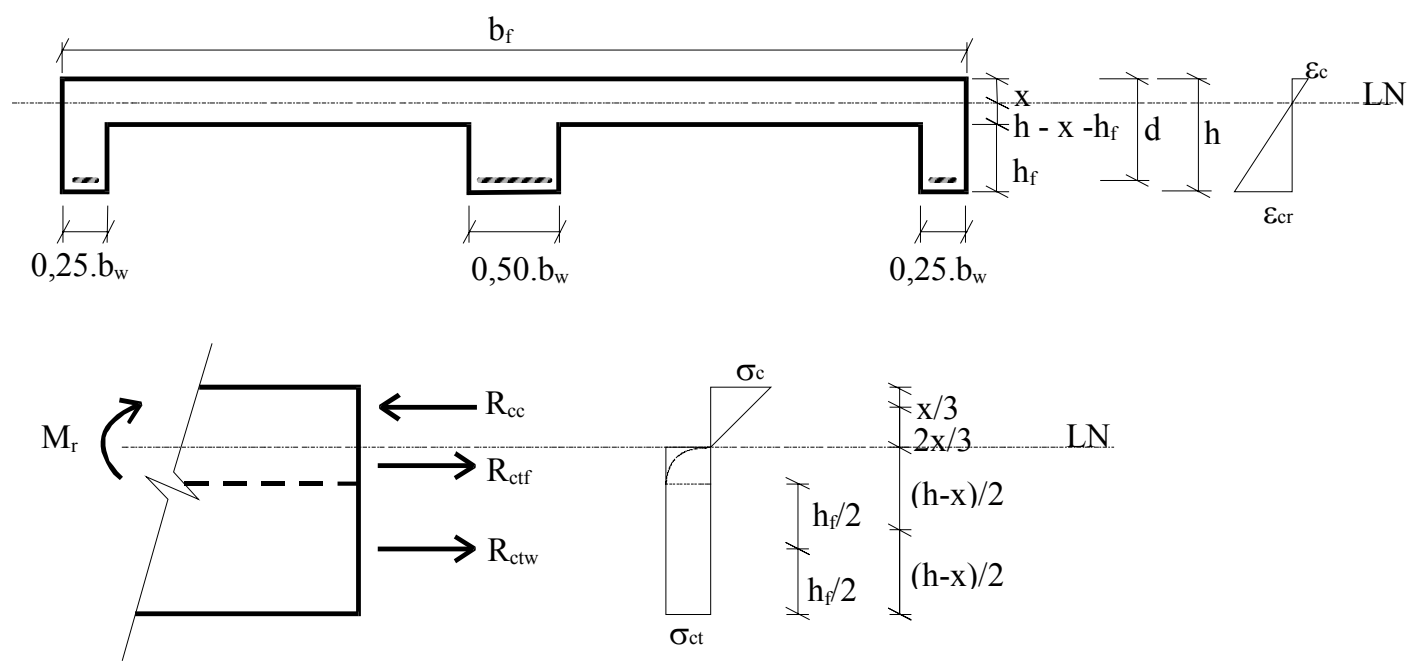

Figura 6.1 - Esquema de solicitação - Estádio Ib (seção simplificada)

Da figura, tem-se:

$\mathrm{R}_{\mathrm{cc}}=\frac{\mathrm{b}_{\mathrm{f}} \cdot \mathrm{x} \cdot \sigma_{\mathrm{c}}}{2}$
$\mathrm{R}_{\mathrm{ctf}}=\sigma_{\mathrm{ct}} \cdot\left(\mathrm{h}-\mathrm{x}-\mathrm{h}_{\mathrm{f}}\right) \cdot \mathrm{b}_{\mathrm{f}}$
$\mathrm{R}_{\mathrm{ctw}}=\sigma_{\mathrm{ct}} \cdot \mathrm{h}_{\mathrm{f}} \cdot \mathrm{b}_{\mathrm{w}}$

Eq. 6.11

Eq. 6.12

Eq. 6.13

onde,

$\sigma_{c}=1,5 \cdot 2,7 \cdot 0,75 \cdot \mathrm{f}_{\mathrm{tk}} \cdot \frac{\mathrm{x}}{\mathrm{h}-\mathrm{x}}$

Eq. 6.14

$\sigma_{c t}=0,75 \cdot \mathrm{f}_{\mathrm{tk}}$

No caso do painel em questão, tem-se $b_{\mathrm{w}}=9 \mathrm{~cm}, \mathrm{~h}=5 \mathrm{~cm}, \mathrm{~h}_{\mathrm{f}}=3 \mathrm{~cm}, \mathrm{~b}_{\mathrm{f}}=$ $40 \mathrm{~cm}$. Substituindo-se esses valores na equação 6.10 e rearranjando-se, obtém-se:

$$
\mathrm{x}=1,46 \mathrm{~cm}
$$

que é a posição da linha neutra teórica.

O binário exercido pelo módulo das forças $R_{c c}, R_{c t w}$ e $R_{c t f}$ é gerado pela ação do momento fletor de fissuração $\left(\mathrm{M}_{\mathrm{r}}\right)$ que, tomando-se como polo o ponto onde se aplica a resultante de compressão $\mathrm{R}_{\mathrm{cc}}$, tem-se:

$$
M_{r}=R_{c t w} \cdot\left[\frac{2 \cdot x}{3}+\left(h-x-h_{f}\right)+\frac{h_{f}}{2}\right]+R_{c t f} \cdot\left[\frac{h-x-h_{f}}{2}+\frac{2 \cdot x}{3}\right] \quad \text { Eq. } 6.17
$$


Substituindo-se os valores de $b_{\mathrm{w}}, \mathrm{h}, \mathrm{h}_{\mathrm{f}}, \mathrm{b}_{\mathrm{f}} \mathrm{e} \mathrm{x}$, convenientemente na expressão 6.17 , tem-se como resultado o seguinte valor para o momento fletor de fissuração:

$$
\mathrm{M}_{\mathrm{r}}=13 \mathrm{kN} . \mathrm{cm}
$$

Este momento fletor é o valor teórico para o qual, acima dele, a peça terá grande probabilidade de sofrer fissuração no concreto quando a peça for submetida à flexão. Como neste caso foram executados ensaios para determinação da resistência à tração e compressão nos concretos relativos a cada painel, estes valores de ensaio foram utilizados nas equações anteriores a fim de se obter o valor do momento fletor de fissuração teórico utilizando-se valores experimentais, os quais correspondem a $28,72 \mathrm{kN} . \mathrm{cm}, 25,66 \mathrm{kN} . \mathrm{cm}$ e $16,36 \mathrm{kN}$.cm para os concretos de referência, com $100 \%$ de reciclados e $50 \%$ de reciclados, respectivamente.

\subsubsection{Verificação do Estado de Deformação Excessiva}

A NBR-6118/78 indica os valores limites dos deslocamentos, decorrentes das deformações, para peças de concreto armado moldadas no local e, no caso de peças pré-moldadas, estes valores são indicados pela NBR-9062.

Conforme NBR-6118/78, os valores limites dos deslocamentos são indicados como:

- 1/500 do vão teórico para deslocamentos causados pela carga acidental,

- $1 / 300$ do vão teórico para deslocamentos causados por todas as ações.

Para elementos pré-moldados, a NBR-9062 indica alguns valores limites em função da utilização do elemento estrutural. Como exemplo, se o elemento for de piso, que não tenha contato ou não suporte elementos não estruturais, os valores limites do deslocamento são:

- 1/200 no caso de flecha medida a longo prazo;

- $1 / 500$ no caso de flecha inicial.

Ambos os limites se aplicam para o caso de todas as cargas estarem atuando na estrutura. 
Para a verificação do estado de deformação excessiva, considera-se a peça em serviço, e portanto, o momento de inércia deve ser calculado no Estádio II, ou seja, peça fissurada e distribuição linear de tensões na parte comprimida da viga. Como a peça é considerada fissurada, o concreto situado na região abaixo da linha neutra não contribui para a resistência da mesma. A posição da linha neutra no Estádio II $\left(\mathrm{x}_{\mathrm{II}}\right)$ é calculada considerando-se que o momento estático da seção comprimida do concreto e da seção de aço da parte inferior, transformada em seção equivalente de concreto, é igual a zero.

Para transformar a área da seção de aço numa área equivalente de concreto, multiplica-se a área da armadura pelo fator $\alpha_{e}$, que vale:

$\alpha_{e}=\frac{\boldsymbol{E}_{s}}{\boldsymbol{E}_{c \mathrm{sec}}}=\frac{210 \cdot 000}{0,85 \cdot 6600 \sqrt{f_{c_{\boldsymbol{k}}}+3,5}}=\frac{210.000}{24 \cdot 129,52}=8,703$

Portanto, a área da seção transversal homogeneizada fica:

$$
\mathrm{A}_{\mathrm{c}_{\text {hom } 0 \mathrm{~g}}}=\alpha_{\mathrm{e}} \cdot \mathrm{A}_{\mathrm{s}}+\mathrm{A}_{\mathrm{cc}}
$$

onde:

$\mathrm{A}_{\mathrm{c} \text { homog }}=$ área da seção transversal homogeneizada

$\mathrm{A}_{\mathrm{s}}$ = área da armadura tracionada;

$\mathrm{A}_{\mathrm{cc}}=$ área comprimida de concreto.

Considerando-se uma viga com seção transversal igual à do painel, calcula-se a seguir o momento de inércia da seção fissurada para o Estádio II ( $\left.\mathrm{I}_{\mathrm{II}}\right)$.

Tomando-se o momento estático da seção em relação à linha neutra, igual a zero, e com base na Figura 6.1, tem-se:

$$
\frac{\mathrm{b}_{\mathrm{f}} \cdot \mathrm{x}_{\mathrm{II}}^{2}}{2}-\alpha_{\mathrm{e}} \cdot \mathrm{A}_{\mathrm{s}} \cdot\left(\mathrm{d}-\mathrm{x}_{\mathrm{II}}\right)=0
$$

A equação quadrática em $x$ fornece, para $b_{\mathrm{f}}=40 \mathrm{~cm}, \alpha_{\mathrm{e}}=8,7, \mathrm{~A}_{\mathrm{s}}=0,24 \mathrm{~cm}^{2} \mathrm{e}$ $\mathrm{d}=3,5 \mathrm{~cm}$, o valor de :

$$
\mathrm{x}_{\mathrm{II}}=0,56 \mathrm{~cm}
$$

Então, o cálculo do momento de inércia em relação à linha neutra é dado por:

$$
\mathrm{I}_{\mathrm{II}}=\frac{\mathrm{b}_{\mathrm{f}} \cdot \mathrm{x}_{\mathrm{II}}^{3}}{3}+\alpha_{\mathrm{e}} \cdot \mathrm{A}_{\mathrm{s}} \cdot\left(\mathrm{d}-\mathrm{x}_{\mathrm{II}}\right)^{2}
$$


Substituindo-se os valores já determinados na Eq. 6.23 resulta:

$$
\mathrm{I}_{\mathrm{II}}=20,39 \mathrm{~cm}^{4}
$$

Deve-se levar em conta que, numa peça fletida, a sua rigidez varia ao longo do eixo. Para se considerar esta variação, utilizou-se a fórmula de Branson - ACI 318 para o cálculo do momento de inércia equivalente $\left(\mathrm{I}_{\mathrm{e}}\right)$ :

$$
I_{e}=\left(\frac{M_{r}}{M_{t o t}}\right)^{3} \cdot I_{I}+\left[1-\left(\frac{M_{r}}{M_{t o t}}\right)^{3}\right] \cdot I_{I I} \leq I_{I}
$$

onde:

$$
\begin{array}{ll}
\mathrm{M}_{\mathrm{r}} & =\text { momento fletor de fissuração; } \\
\mathrm{M}_{\mathrm{tot}} & =\text { momento fletor total devido a todas as ações; } \\
\mathrm{I}_{\mathrm{I}} & =\mathrm{I}_{\mathrm{X}} ; \\
\mathrm{I}_{\mathrm{II}} & =\text { Eq. } 6.24 .
\end{array}
$$

Substituindo-se os valores de $\mathrm{M}_{\mathrm{r}}=13 \mathrm{kN} . \mathrm{cm}, \mathrm{M}_{\mathrm{tot}}=38,27 \mathrm{kN} . \mathrm{cm}, \mathrm{I}_{\mathrm{I}}=$ $173,085 \mathrm{~cm}^{4}, \mathrm{I}_{\mathrm{II}}=20,39 \mathrm{~cm}^{4}$, obtém-se o valor do momento de inércia teórico equivalente:

$$
\mathrm{I}_{\mathrm{e}}=26,38 \mathrm{~cm}^{4}
$$

Finalmente, calcula-se o deslocamento teórico para as duas situações de carregamento dado pelas Eq. 6.4 e 6.5, considerando-se ação de longa duração distribuída em todo o comprimento $\mathrm{L}\left(\delta_{1}\right)$, ou ação concentrada aplicada nos terços do vão $\left(\delta_{2}\right)$. Dessa forma, tem-se:

$$
\begin{aligned}
& \delta_{1}=\frac{5}{384} \cdot \frac{\mathrm{q} \cdot \mathrm{L}^{4}}{\mathrm{E}_{\mathrm{c}} \cdot \mathrm{I}_{\mathrm{e}}} \\
& \delta_{2}=\frac{23}{1296} \cdot \frac{\mathrm{F} \cdot \mathrm{L}^{3}}{\mathrm{E}_{\mathrm{c}} \cdot \mathrm{I}_{\mathrm{e}}}
\end{aligned}
$$

Essas equações fornecem as seguintes flechas teóricas $\delta_{1}=3,76 \mathrm{~cm}(37,6 \mathrm{~mm})$ e $\delta_{2}=3,85 \mathrm{~cm}(38,5 \mathrm{~mm})$.

A flecha calculada não deve ultrapassar os valores limites estabelecidos pela NBR-9062, apresentados anteriormente. Quando atuarem todas as ações, temse, para flecha máxima teórica: 


$$
\mathrm{a}_{\max }=\frac{\mathrm{L}}{300}=\frac{2450}{300}=0,8167 \mathrm{~cm} \cong 8,2 \mathrm{~mm}
$$

Como a flecha teórica calculada foi maior que a admissível pela norma, para atender a esta restrição, a viga deveria ser moldada com uma contra-flecha de $29,4 \mathrm{~mm}$ ou 30,3 mm (conforme o tipo de ações atuantes), sendo que estes valores devem ser indicados no projeto.

\subsection{Programa Experimental}

Os painéis foram submetidos a ensaios de flexão, aos 7 dias, com carregamento aplicado nos terços do vão até que eles atingissem a ruptura. Corpos-de-prova para ensaios de resistência à compressão, resistência à tração, determinação do módulo tangente de elasticidade, absorção, índice de vazios e massa específica do concreto endurecido, foram moldados para cada tipo de agregado graúdo utilizado nas misturas.

\subsection{Dimensões dos Componentes}

O planejamento da pesquisa previu a execução de três painéis leves nervurados, para vedação, com dimensões de $400 \mathrm{~mm}$ de largura e $2.500 \mathrm{~mm}$ de comprimento, definindo-se um vão teórico de $2.450 \mathrm{~mm}$, moldados com as misturas ensaiadas preliminarmente. A espessura total do painel é de $50 \mathrm{~mm}$, sendo a mesa com $20 \mathrm{~mm}$ e a parte das nervuras acrescidas de $30 \mathrm{~mm}$. Os componentes adotados possuem 3 nervuras; 2 nas extremidades laterais com $20 \mathrm{~mm}$ de largura e uma na parte central com $40 \mathrm{~mm}$ de largura final. Foram adotadas as mesmas dimensões para todos os painéis.

Na Figura 6.2 é apresentada a seção típica do painel utilizado contendo as dimensões totais e das nervuras. Em seguida, na Figura 6.3, apresenta-se as configurações do sistema construtivo, inicialmente proposto para construção de habitações populares, mostrando o posicionamento do painel nos encontros de parede: 


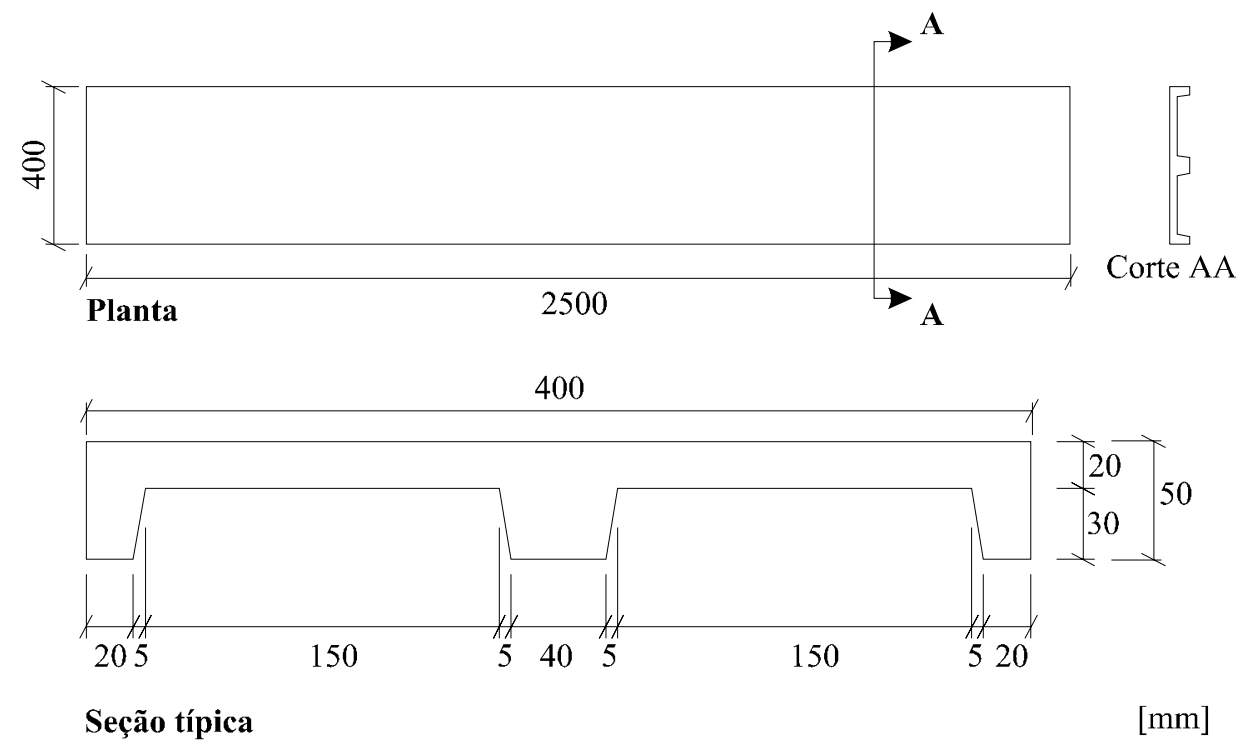

Figura 6.2 - Dimensões do painel e da seção típica

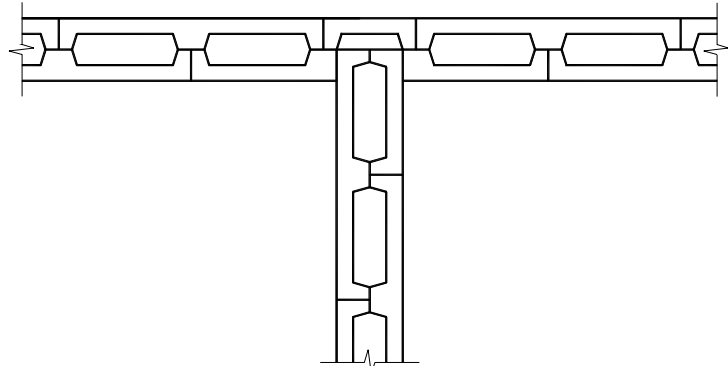

(a)

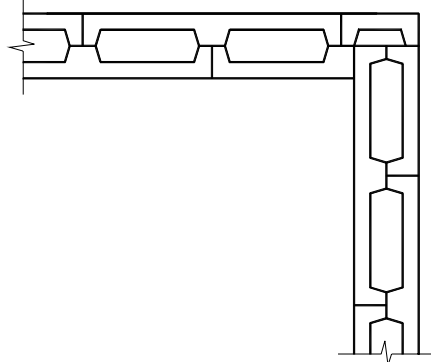

(b)

Figura 6.3 - Posicionamento do painel: (a) encontro no meio da parede; (b) encontro no canto da parede

\subsection{Fôrmas e Armaduras para os Painéis}

Para a moldagem dos painéis, foram utilizadas as fôrmas metálicas que se encontravam no Laboratório de Estruturas da EESC - USP, usadas no anteprojeto de painéis pré-fabricados. Como só havia um conjunto de fôrmas, cada painel foi moldado separadamente.

Apesar da espessura reduzida das peças, a análise feita neste estudo considera, para efeito de cálculo, o comportamento dos painéis como de concreto armado. Portanto, utilizou-se o dimensionamento de peças de concreto armado 
comum, para uma força total distribuída de $58 \mathrm{~N} / \mathrm{m}$ e considerando-se a utilização de um concreto classe $\mathrm{C}-15$, o que resultou em uma taxa de armadura de $60 \mathrm{~kg} / \mathrm{m}^{3}$.

Considerando-se o alojamento das armaduras, adotou-se 1 fio de aço, do tipo CA 60 - B, com diâmetro de 3,2 mm colocado na parte inferior e superior das nervuras, e 2 fios de mesmo diâmetro colocados na mesa para efeito de distribuição. Os estribos foram espaçados a cada $25 \mathrm{~cm}$. O cobrimento mínimo das armaduras adotado neste caso foi de $6 \mathrm{~mm}$. Considerando-se a posição da armadura inferior, a altura útil (d) da peça ficou igual a $35 \mathrm{~mm}$, e o seu arranjo está mostrado na Figura 6.4:
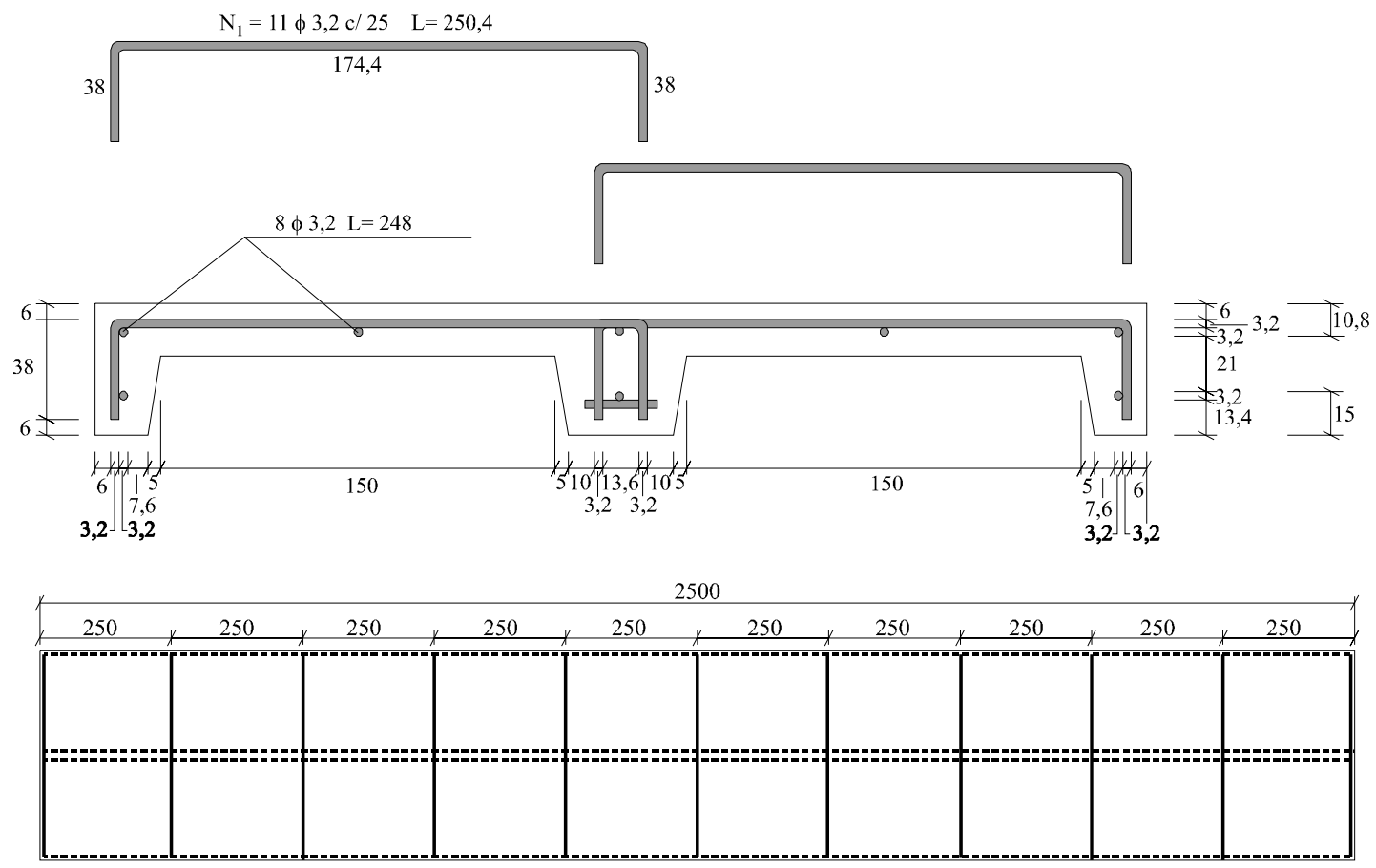

Figura 6.4 - Arranjo da armadura no painel

\subsection{Materiais Utilizados nos Ensaios}

Os agregados reciclados utilizados para confecção dos painéis foram os da amostra representativa que foi coletada na estação de reciclagem de Ribeirão Preto em meados de abril de 1997. Devido às pequenas dimensões do painel, adotou-se como agregado graúdo aquele correspondente à faixa 
granulométrica para brita 0 , ou seja, agregado com dimensão máxima característica $D_{\text {máx }}=9,5 \mathrm{~mm}$.

Os painéis foram moldados com concreto preparado na proporção $1: 2,83: 2,33$ para agregado natural e, a partir deste, os traços foram ajustados para agregados reciclados, tentando-se manter as mesmas proporções e fator água/cimento (em torno de 0,68 ). O cimento utilizado foi o CP II E- 32, com um consumo de cimento da ordem de $335 \mathrm{~kg} / \mathrm{m}^{3}$ de concreto. Como agregado miúdo utilizou-se a areia natural do rio Mogi-Guaçu, na região de São Carlos.

\subsection{Ensaio à Flexão dos Painéis}

Os agregados graúdos natural e reciclado e o agregado miúdo, utilizados para confecção dos painéis, foram submetidos a ensaios para determinação da absorção, índices de vazios e massa específica no estado seco e saturado superfície seca, tendo suas características já estudadas e apresentadas no capítulo 5.

Apresenta-se a seguir como foram realizados os ensaios à flexão e as diversas etapas envolvidas.

\subsubsection{Moldagem, Adensamento e Cura}

Primeiramente a fôrma foi preparada e untada com produto à base de óleo desmoldante. As armaduras eram todas preparadas e amarradas nas bancadas de trabalho e depois de prontas, alojadas cuidadosamente na fôrma, observando-se os espaçamentos indicados no projeto. Figura 6.5 (a).

Uma vez confeccionado o concreto, a fôrma do painel foi colocada em cima de uma mesa vibratória, responsável pelo adensamento do material. $\mathrm{O}$ preenchimento dava-se da seguinte maneira: com uma colher de pedreiro, fazia-se o preenchimento primeiramente ao longo das 3 nervuras, Figura 6.5 (b), seguido de um adensamento prévio, ligando-se a mesa vibratória por alguns segundos. Então completava-se o restante da fôrma e novamente a mesa vibratória era acionada. Finalmente com uma régua, uma desempenadeira e uma colher de pedreiro fazia-se a regularização, desempenando-se e alisando-se a superfície dos painéis. Figura 6.5 (c). 
O painel permaneceu em cura úmida por 24 horas, na fôrma. Após a desforma foi curado ao ar, em ambiente protegido. Todos os ensaios foram realizados com idades de 7 dias.

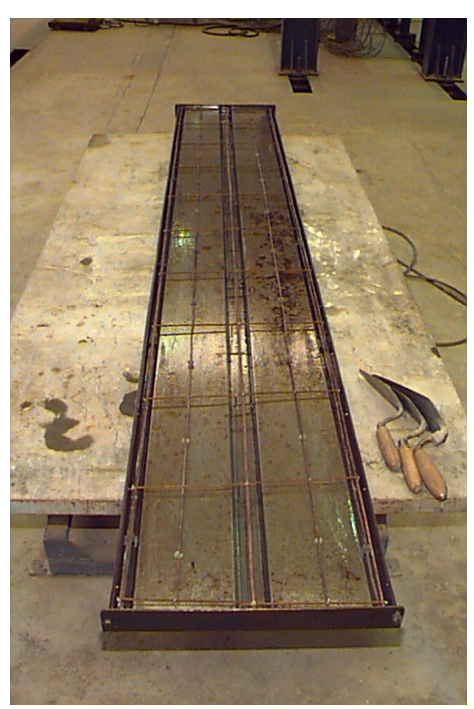

(a)

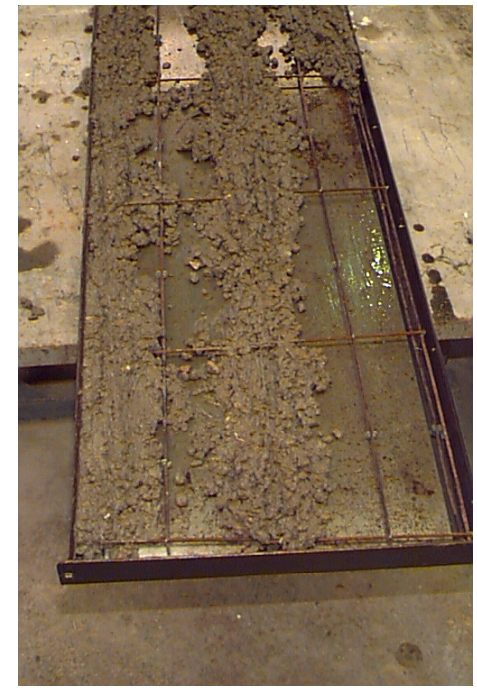

(b)

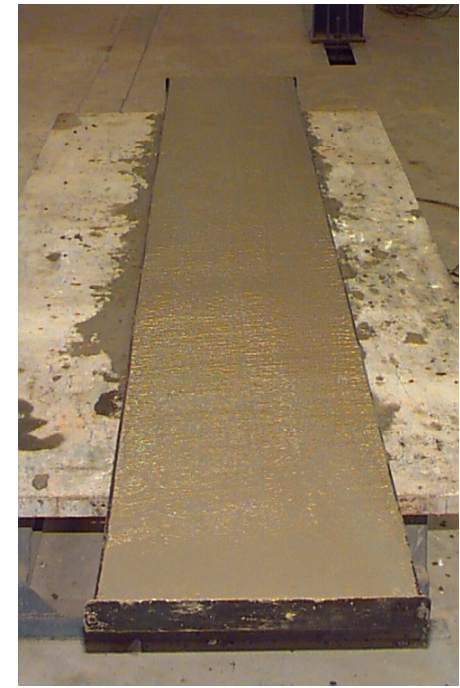

(c)

Figura 6.5 - (a) fôrma do painel com armadura alojada;

(b) preenchimento das nervuras;

(c) fôrma totalmente preenchida.

\subsubsection{Esquema Estático e de Carregamento}

Os protótipos foram submetidos à ação de uma força concentrada, aplicada de cima para baixo, substituindo-se a força uniformemente distribuída por 2 forças concentradas, aplicadas aproximadamente nos terços do vão, segundo $o$ esquema estático e de carregamento mostrado na Figura 6.6. 


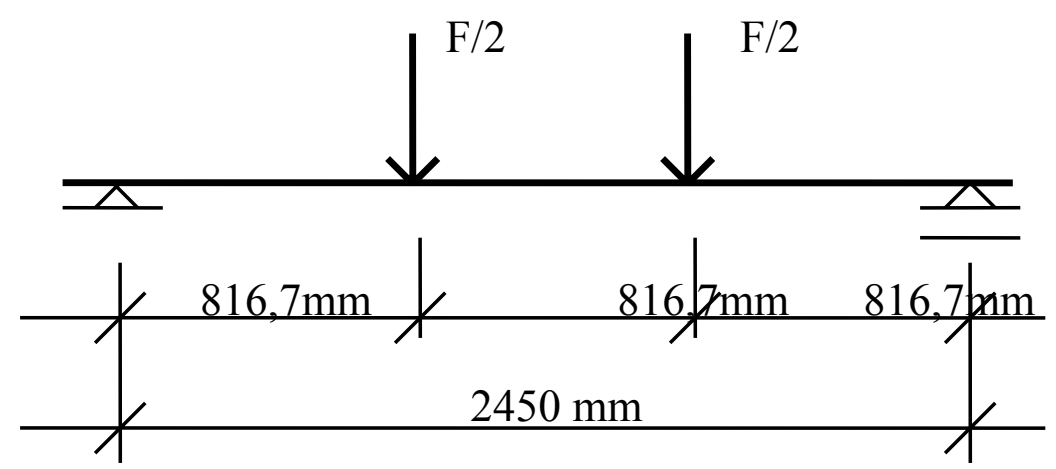

Figura 6.6 - Esquema estático e de carregamento do painel

A força atuante foi aplicada através de um cilindro hidráulico de capacidade $200 \mathrm{kN}$ acoplado à uma bomba hidráulica de acionamento manual, montados no Laboratório de Estruturas como pode ser visto na Figura 6.7:

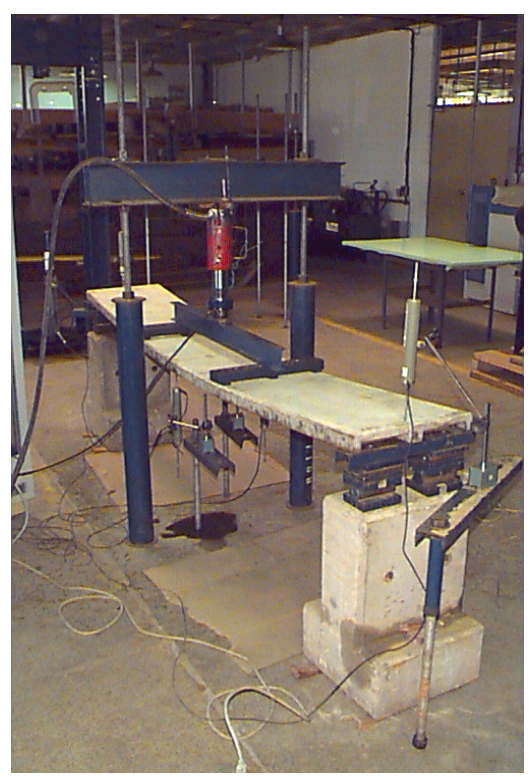

Figura 6.7 - Aparelhagem para aplicação de força

\subsubsection{Instrumentação}

Para se fazer aplicação e medição da força utilizou-se uma célula de carga com capacidade de $50 \mathrm{kN}$. 
Os deslocamentos transversais do painel foram medidos por meio de transdutores elétricos com sensibilidade de $0,5 \mathrm{~mm}$ e curso de $100 \mathrm{~mm}$, posicionados em 4 pontos ao longo do painel: 2 na seção transversal média e 2 junto aos apoios, como mostrado na Figura 6.8:

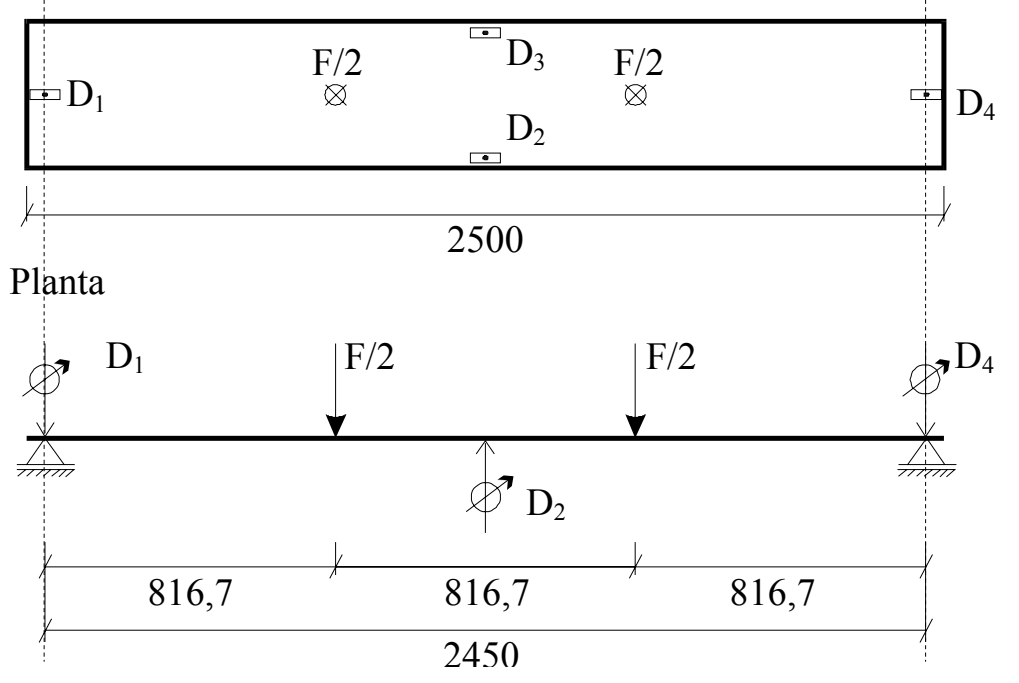

Figura 6.8 - Localização dos transdutores elétricos no painel ensaiado

\subsubsection{Ensaio de Avaliação do Comportamento à Flexão dos Painéis}

Durante cada etapa de aplicação de forças, foram sendo registrados os deslocamentos ocorridos e a força relativa a eles. Um sistema de aquisição de dados computadorizado registrou as leituras indicadas pela célula de carga e pelos transdutores. No decorrer dos ensaios foram anotadas as cargas responsáveis pela primeira fissura e o surgimento das fissuras posteriores conforme os acréscimos de carregamento. A Figura 6.9 mostra o aparato de ensaio utilizado (a) e um detalhe do apoio móvel (b).

A execução dos ensaios de flexão simples nos painéis nervurados, foi realizada à semelhança de uma viga simplesmente apoiada, de modo que o carregamento fizesse com que o painel atingisse o colapso. A magnitude total da força de ruptura foi prevista através do cálculo do momento no estado limite último. Igualando-se os momentos fletores gerados pelos 2 tipos de 
forças, obteve-se o valor da força total equivalente para execução do ensaio, que foi de $1080 \mathrm{~N}$. Os incrementos de carga foram da ordem de $100 \mathrm{~N}$.

A fim de se fazer a acomodação da peça à aparelhagem de ensaio, aplicou-se um carregamento inicial, conhecido como escorvamento, no valor de $100 \mathrm{~N}$ (um incremento de carga), descarregando-se logo em seguida. Na seqüência deu-se início ao ensaio com etapas crescentes de carregamento.

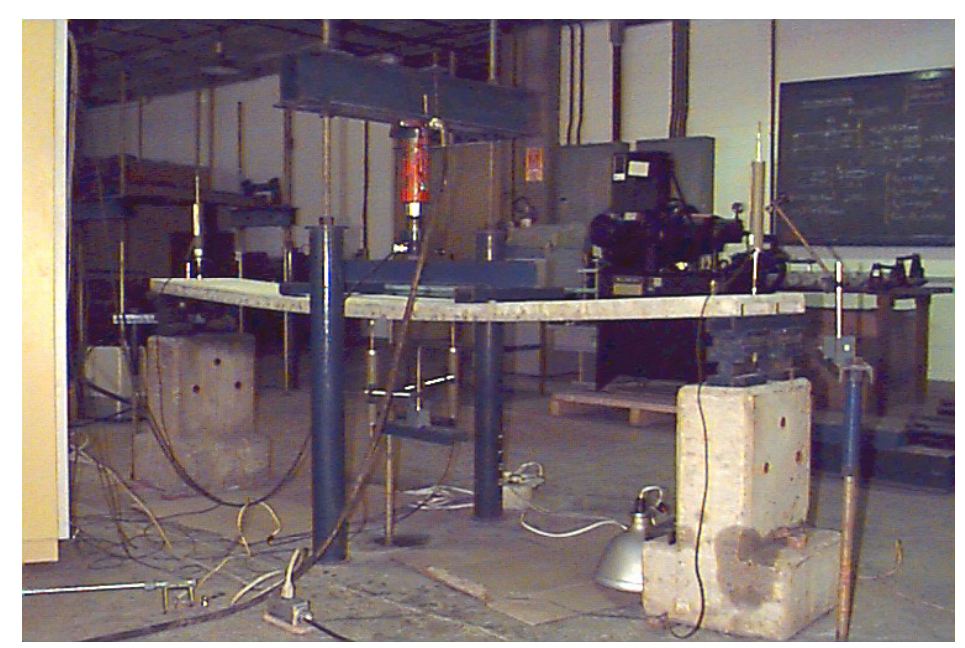

(a)

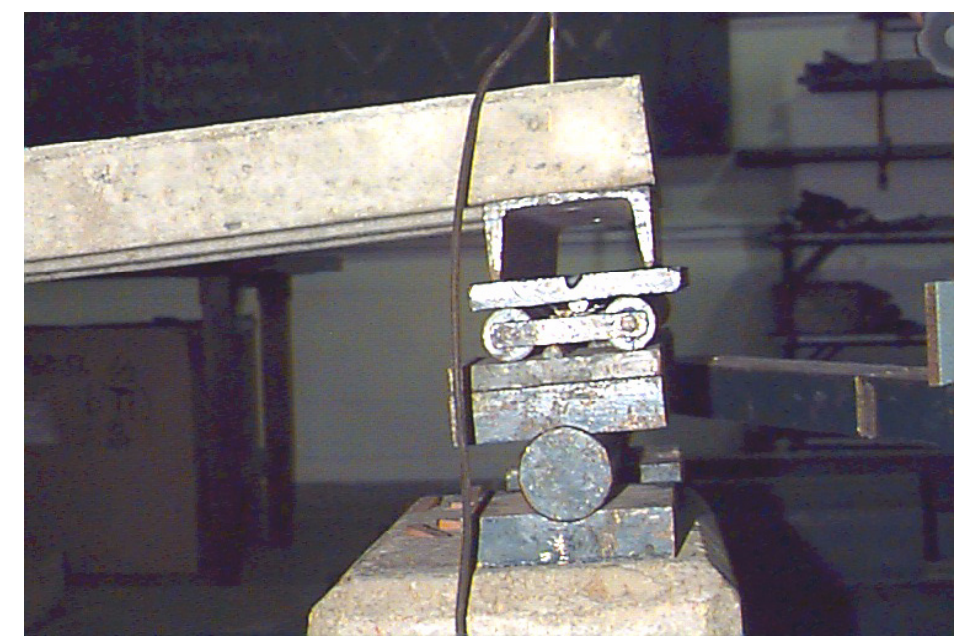

(b)

Figura 6.9 - Aparato de ensaio à flexão com detalhe do apoio móvel

No capítulo seguinte são apresentados os resultados dos ensaios à flexão realizados nos painéis e comentários são efetuados em relação aos valores obtidos. 


\section{APRESENTAÇÃO DOS RESULTADOS}

\subsection{Considerações Gerais}

É importante observar que os estudos realizados nos painéis foram efetuados logo no início das pesquisas, quando do recebimento do material em abril de 1997. Assim, as determinações de algumas das características físicas dos agregados foram concluídas posteriormente à data da realização dos ensaios nos painéis.

Com isto, decorre que, as quantidades de materiais utilizadas nestes concretos foram apenas substituídas em massa, em função dos ensaios iniciais, acrescentando-se mais ou menos água à mistura, sem que houvesse ajuste nos traços. A Tabela 7.1 apresenta os valores do abatimento e fator água/cimento para os concretos utilizados nos painéis:

Tabela 7.1 - Fator água/cimento e abatimento dos concretos dos painéis

\begin{tabular}{cccc}
\hline $\begin{array}{c}\text { tipo de concreto } \\
\left(\mathrm{D}_{\max }=9,5 \mathrm{~mm}\right)\end{array}$ & natural & $\begin{array}{l}50 \% \text { natural }+ \\
50 \% \text { reciclado }\end{array}$ & $100 \%$ reciclado \\
\hline abatimento $(\mathrm{mm})$ & 7 & 12 & 29 \\
\hline fator $\mathrm{a} / \mathrm{c}$ & 0,64 & 0,68 & 0,74 \\
\hline
\end{tabular}

Para o concreto com $100 \%$ de agregados graúdos reciclados, devido aos estudos preliminares, acrescentou-se mais água à mistura, resultando um fator água/cimento maior. 
Para o concreto utilizando-se agregados naturais, foi estimado um valor de $3 \%$ para a umidade da areia, diminuindo-se a quantidade de água equivalente. Pode-se explicar, em decorrência deste fato, o menor abatimento deste concreto em relação aos outros.

\subsection{Apresentação e Discussão dos Resultados}

Juntamente com a moldagem dos painéis, corpos-de-prova cilíndricos de 10 $\mathrm{cm}$ de diâmetro por $20 \mathrm{~cm}$ de altura, correspondentes a cada tipo de concreto, foram submetidos a ensaios de compressão, axial e diametral, determinando-se as resistências médias e o módulo de elasticidade na data dos ensaios dos painéis e aos 28 dias.

Os resultados dos ensaios nos concretos dos painéis com agregados naturais e reciclados podem ser vistos na Tabela 7.2:

Tabela 7.2 - Corpos-de-prova cilíndricos. Média dos resultados

\begin{tabular}{|c|c|c|c|c|}
\hline $\begin{array}{l}\text { idade } \\
\text { (dias) }\end{array}$ & $\begin{array}{c}\text { tipo de } \\
\text { concreto } \\
\left(\mathrm{D}_{\text {máx }}=9,5 \mathrm{~mm}\right)\end{array}$ & $\begin{array}{c}\text { compressão } \\
\text { axial } \\
(\mathrm{MPa})\end{array}$ & $\begin{array}{l}\text { compressão } \\
\text { diametral } \\
(\mathrm{MPa})\end{array}$ & $\begin{array}{l}\text { módulo de elast. } \\
\text { tangente } \\
(\mathrm{MPa})\end{array}$ \\
\hline \multirow{3}{*}{7} & natural & $(1,00)$ & $2,35 \quad(1,00)$ & $9.826 \quad(1,00)$ \\
\hline & $\begin{array}{l}50 \% \text { natural }+ \\
50 \% \text { reciclado }\end{array}$ & $(0,95)$ & $(0,90)$ & $11.349 \quad(1,15)$ \\
\hline & $100 \%$ reciclado & $16,0 \quad(0,76)$ & $1,29 \quad(0,55)$ & $8.725 \quad(0,89)$ \\
\hline \multirow{3}{*}{28} & natural & $(1,00)$ & - & $16.948 \quad(1,00)$ \\
\hline & $\begin{array}{l}50 \% \text { natural }+ \\
50 \% \text { reciclado }\end{array}$ & $(0,84)$ & - & $15.323 \quad(0,90)$ \\
\hline & $100 \%$ reciclado & $21,2 \quad(0,65)$ & - & $12.295 \quad(0,73)$ \\
\hline
\end{tabular}

Observando-se a Tabela 7.2 pode-se perceber que a resistência à compressão aos 7 e aos 28 dias, para o concreto com $100 \%$ de agregado graúdo reciclado, chegou a um valor médio em torno de $16 \mathrm{MPa}$ e $21,2 \mathrm{MPa}$, ficando $24 \%$ e $35 \%$ abaixo dos valores para o concreto de referência. O concreto com $50 \%$ de reciclados apresentou-se $5 \%$ e $16 \%$ menor, aos 7 e 28 dias. 
Ao contrário dos resultados obtidos nos ensaios preliminares, apresentados no capítulo 4, as resistências médias, à compressão axial, dos concretos com agregados reciclados foram mais baixas que o de referência. Entretanto, analisando-se os resultados dos vários corpos-de-prova individualmente, observou-se que os valores obtidos nos ensaios não apresentaram um índice de dispersão muito elevado em relação à média, o que pode representar uma certa constância no comportamento do material reciclado.

A resistência à tração do concreto com 100\% de agregado graúdo reciclado, medida no ensaio por compressão diametral, foi aproximadamente a metade dos outros dois concretos. No entanto, as relações de resistência para os ensaios à compressão axial e diametral foram as previsíveis no início das pesquisas.

Já os valores dos módulos de elasticidade foram aproximadamente iguais para os três tipos de concretos, aos 7 dias, e com valores decrescentes em relação ao concreto de referência, aos 28 dias, como era esperado. Para o concreto com $100 \%$ de agregado graúdo reciclado o módulo apresentou-se 11,2\% mais baixo do que o valor de referência, chegando a $8.725 \mathrm{MPa}$, aos 7 dias.

Para o concreto endurecido, foram também efetuados ensaios, aos 28 dias, para determinação da absorção, índice de vazios e massa específica, segundo a NBR 9778/87 "Argamassa e Concretos Endurecidos - Determinação da Absorção de Água por Imersão - Índice de Vazios e Massa Específica”, e os resultados estão apresentados na Tabela 7.3:

Tabela 7.3 - Absorção, índice de vazios e massa específica dos concretos

\begin{tabular}{|c|c|c|c|c|c|}
\hline $\begin{array}{l}\text { tipo de } \\
\text { concreto }\end{array}$ & $\begin{array}{c}\text { absorção } \\
(\%)\end{array}$ & $\begin{array}{c}\text { índice de } \\
\text { vazios } \\
(\%)\end{array}$ & $\begin{array}{c}\gamma_{\mathrm{s}} \\
\left(\mathrm{kg} / \mathrm{m}^{3}\right)\end{array}$ & $\begin{array}{c}\gamma_{\mathrm{sss}} \\
\left(\mathrm{kg} / \mathrm{m}^{3}\right)\end{array}$ & $\begin{array}{c}\gamma \\
\left(\mathrm{kg} / \mathrm{m}^{3}\right)\end{array}$ \\
\hline natural & $5,23(1,00)$ & $11,82(1,00)$ & $2259(1,00)$ & $2377(1,00)$ & $2562(1,00)$ \\
\hline $\begin{array}{l}50 \% \text { natural }+ \\
50 \% \text { reciclado }\end{array}$ & $6,51(1,24)$ & $13,92(1,18)$ & $2139(0,95)$ & $2278(0,96)$ & $2485(0,97)$ \\
\hline $100 \%$ reciclado & $8,04(1,54)$ & $16,19(1,37)$ & $2013(0,89)$ & $2175(0,92)$ & $2402(0,94)$ \\
\hline
\end{tabular}

onde:

$\gamma_{\mathrm{s}} \quad=$ massa específica da amostra seca;

$\gamma_{\mathrm{sss}} \quad=$ massa específica da amostra saturada superfície seca;

$\gamma \quad=$ massa específica real.

Observando-se a Tabela 7.3, pode-se constatar que, a absorção e o índice de vazios do concreto com $50 \%$ de agregado graúdo reciclado foram, 
respectivamente, 1/4 e 1/5 maiores do que o de referência, dobrando a relação para o concreto com $100 \%$ de substituição.

A massa específica seca do concreto com $100 \%$ de agregado reciclado, com valor de $2.013 \mathrm{~kg} / \mathrm{m}^{3}$, está localizada no limite superior dos concretos leves $\left(\gamma_{\mathrm{s}}=1.900 \mathrm{~kg} / \mathrm{m}^{3}\right)$, e inferior dos concretos normais $\left(\gamma_{\mathrm{s}}=2.100 \mathrm{~kg} / \mathrm{m}^{3}\right)$. As massas específicas dos concretos com reciclados são diretamente proporcionais às resistências à compressão, tração e módulo de elasticidade e inversamente proporcionais à absorção e índice de vazios. $\mathrm{O}$ concreto com $100 \%$ de agregado graúdo reciclado, apresentou absorção de $8 \%$, que é o máximo admissível para tubos de concreto armado segundo a NBR-9794/87 e postes de concreto armado pela NBR-8451/85.

O desempenho, à flexão, dos painéis moldados utilizando-se concreto preparado com agregados graúdos reciclados, frente ao painel de referência, pode ser avaliado através das curvas força $\mathrm{x}$ deslocamento transversal, que estão apresentadas na Figura 7.1:

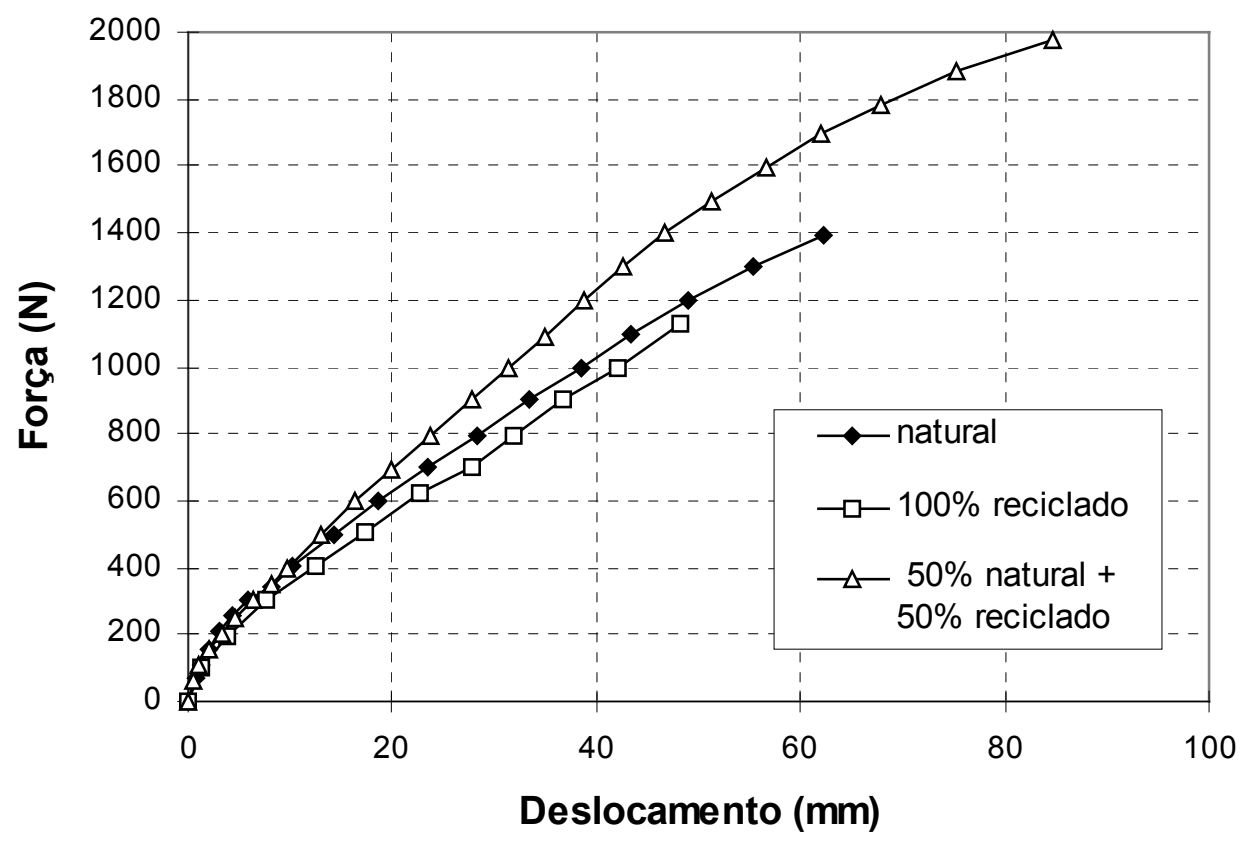

Figura 7.1 - Gráfico força $x$ deslocamento transversal, para os 3 tipos de painéis

Os gráficos exibem 3 diferentes estágios que correspondem às condições de não fissurado, fissurado e escoado. Estas situações apresentam-se mais nítidas para os concretos com agregados naturais e com $50 \%$ de reciclados, porém 
para o concreto com $100 \%$ de graúdo reciclado, a fase de escoamento torna-se mais difícil de ser identificada.

O painel preparado com agregados naturais apresentou início de fissuração visível com uma força de aproximadamente $350 \mathrm{~N}$, conferindo uma flecha experimental de $8 \mathrm{~mm}$. Para os concretos com $50 \%$ e $100 \%$ de reciclados, a fissuração visível deu-se para forças de $400 \mathrm{~N}$ e $200 \mathrm{~N}$, conferindo flechas respectivas de $10 \mathrm{~mm}$ e $4 \mathrm{~mm}$. A fase de fissuração pode ser notada graficamente (Figura 7.1) pela mudança de inclinação logo no início das curvas.

A força teórica calculada para se atingir a fissuração foi de aproximadamente 320 N. Sendo a força total teórica calculada para se levar o painel até a ruína muito maior (em torno de $1.080 \mathrm{~N}$ ), após a realização do primeiro ensaio, onde se percebeu que as fissuras começavam a aparecer logo no início dos primeiros incrementos de aplicação de força, optou-se então por diminuir, de $100 \mathrm{~N}$ para $50 \mathrm{~N}$, as etapas de carregamento para os ensaios subsequentes, a fim de se obter um melhor acompanhamento da evolução da fissuração.

Após a fissuração, para os 3 tipos de concretos, as curvas apresentaram um comportamento praticamente linear, até as forças de $1.150 \mathrm{~N}, 1.400 \mathrm{~N}$ e 1.000 $\mathrm{N}$, para concretos com agregados naturais, $50 \%$ reciclados e $100 \%$ reciclados, com flechas de aproximadamente $50 \mathrm{~mm}, 47 \mathrm{~mm}$ e $41 \mathrm{~mm}$ respectivamente, onde presume-se, pela nova mudança de inclinação das curvas, que houve escoamento da armadura.

O desempenho inferior do painel com $100 \%$ de agregado graúdo reciclado, está de acordo com os resultados apresentados na Tabela 7.2, relativos aos ensaios de resistência à compressão e tração. As curvas obtidas, estão perfeitamente de acordo com os respectivos módulos de elasticidade, na data dos ensaios dos painéis aos 7 dias.

Para o painel de referência, as leituras dos deslocamentos medidas pelos transdutores elétricos foram efetuadas para carregamento até $1.400 \mathrm{~N}$ quando, a partir de então, os aparelhos de leitura foram retirados, evitando-se assim possíveis danos aos mesmos, caso o painel viesse a sofrer ruptura. A força máxima neste caso foi de $1.660 \mathrm{~N}$. Este mesmo procedimento foi adotado para os demais painéis que chegaram a forças máximas de $1.150 \mathrm{~N}$ e $1.800 \mathrm{~N}$ para os concretos com $100 \%$ e $50 \%$ de agregados reciclados respectivamente.

As forças medidas relativas aos momentos últimos experimentais, para os painéis, superaram a força para o momento último teórico de cálculo, que foi de $1.080 \mathrm{~N}$, alcançando índices de 1,06 e 1,30 para os concretos com agregado natural, e $50 \%$ reciclado. Para concreto com $100 \%$ de reciclado este índice 
ficou em 0,93, sem ocorrer, no entanto, o colapso em nenhum dos painéis. Toda armadura situada abaixo da linha neutra está assumida escoada, devido à enorme deflexão última a que o painel foi levado.

Ao se retirar os esforços atuantes conferidos aos painéis, através do equipamento hidráulico, estes apresentaram uma tendência a retornar à posição original (horizontal no plano dos apoios), permanecendo ainda, em média, com uma flecha de $75 \mathrm{~mm}$.

Os momentos fletores últimos obtidos experimentalmente foram comparados com o momento fletore último teórico calculado utilizando-se aproximação de concreto armado convencional. Nesta aproximação a armadura nas nervuras é assumida escoada por causa dos altos deslocamentos últimos obtidos nos painéis. Para painéis rompidos à flexão, a aproximação com concreto convencional parece predizer a capacidade última à flexão com razoável acuidade.

É apresentado na Tabela 7.4 a comparação entre os valores experimentais e teóricos dos momentos fletores de fissuração utilizando-se valores de ensaio e dos momentos fletores últimos. A comparação entre os valores das flechas experimentais e teóricos também utilizando-se valores de ensaios, estão apresentados na Tabela 7.5:

Tabela 7.4 - Comparação entre os momentos fletores teóricos e experimentais

\begin{tabular}{|c|c|c|c|c|c|}
\hline $\begin{array}{l}\text { tipo de } \\
\text { concreto }\end{array}$ & & $\begin{array}{l}\text { Momento fle } \\
\text { de fissuraçãa } \\
\text { (kN.cm) }\end{array}$ & & & $\begin{array}{l}\text { Momento } \\
\text { fletor } \\
\text { último }\end{array}$ \\
\hline $\mathrm{D}_{\text {máx }}=9,5 \mathrm{~mm}$ & experimental & $\begin{array}{c}\text { teórico com valores } \\
\text { experimentais }\end{array}$ & teórico & experimental & teórico \\
\hline natural & $14,29(0,50)$ & 28,72 & 13 & $46,96(1,23)$ & 38,27 \\
\hline $\begin{array}{l}50 \% \text { natural }+ \\
50 \% \text { reciclado }\end{array}$ & $16,33(0,64)$ & 25,66 & 13 & $57,17(1,49)$ & 38,27 \\
\hline $100 \%$ reciclado & $8,17(0,50)$ & 16,36 & 13 & $40,83(1,07)$ & 38,27 \\
\hline
\end{tabular}




\section{Tabela 7.5 - Comparação entre as flechas experimentais e teóricas}

\begin{tabular}{|c|c|c|c|c|c|}
\hline \multirow{2}{*}{$\begin{array}{c}\text { tipo de } \\
\text { concreto } \\
\mathrm{D}_{\text {máx }}=9,5 \mathrm{~mm}\end{array}$} & \multicolumn{3}{|c|}{$\begin{array}{l}\text { FLECHAS para momento } \\
\text { fletor de fissuração } \\
(\mathrm{mm})\end{array}$} & \multicolumn{2}{|c|}{$\begin{array}{c}\text { Momento fletor } \\
\text { último } \\
(\mathrm{kN.cm})\end{array}$} \\
\hline & experimental & $\begin{array}{l}\text { teórico com } \\
\text { valores } \\
\text { experimentai } \\
\mathrm{s}\end{array}$ & teórico & experimental & teórico \\
\hline natural & $8(0,67)$ & 28,72 & 2 & $50(1,30)$ & 38,5 \\
\hline $\begin{array}{l}50 \% \text { natural }+ \\
50 \% \text { reciclado }\end{array}$ & $10(0,65)$ & 25,66 & 2 & $47(1,22)$ & 38,5 \\
\hline $100 \%$ reciclado & $4(0,13)$ & 16,36 & 2 & $41(1,06)$ & 38,5 \\
\hline
\end{tabular}

Para o painel contendo concreto com agregados naturais e com $100 \%$ de agregado reciclado, o momento fletor de fissuração ficou a metade do momento fletor de cálculo. Para o concreto com $50 \%$ de reciclados o momento ficou $36 \%$ menor do que o valor teórico. Em relação ao momento último os valores experimentais superaram os valores de cálculo em todos os casos.

Quanto aos valores das flechas os painéis atingiram 67\% e 65\% dos valors teóricos para concreto com agregados naturais e $50 \%$ de substituição. Para o concreto com $100 \%$ de graúdo reciclado a flecha ficou $87 \%$ menor. Todos os valores de flechas para momento fletor último atingiram valores maiores do que os de ensaio.

As curvas Tensão $\times$ Deformação do concreto sob compressão, estão apresentadas na Figura 7.2 (a) e (b), aos 7 e aos 28 dias, respectivamente. As curvas, para todos os concretos são lineares até aproximadamente $0,0005 \mathrm{~mm}$. A curva Tensão $\times$ Deformação para concretos contendo agregado reciclado estão próximas daquelas do concreto de controle. 


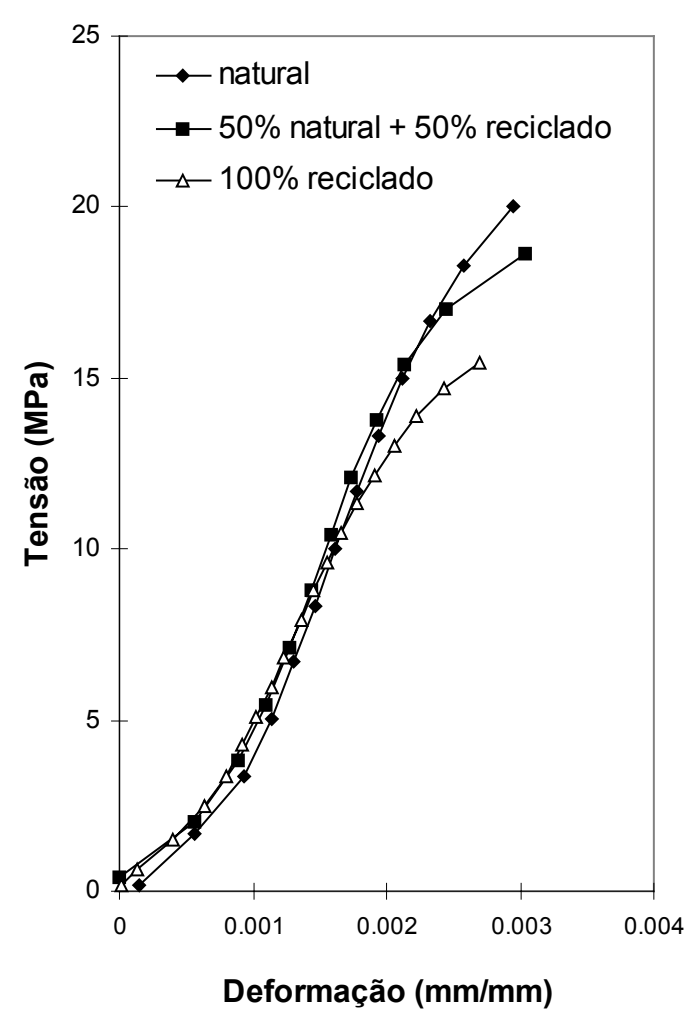

a)

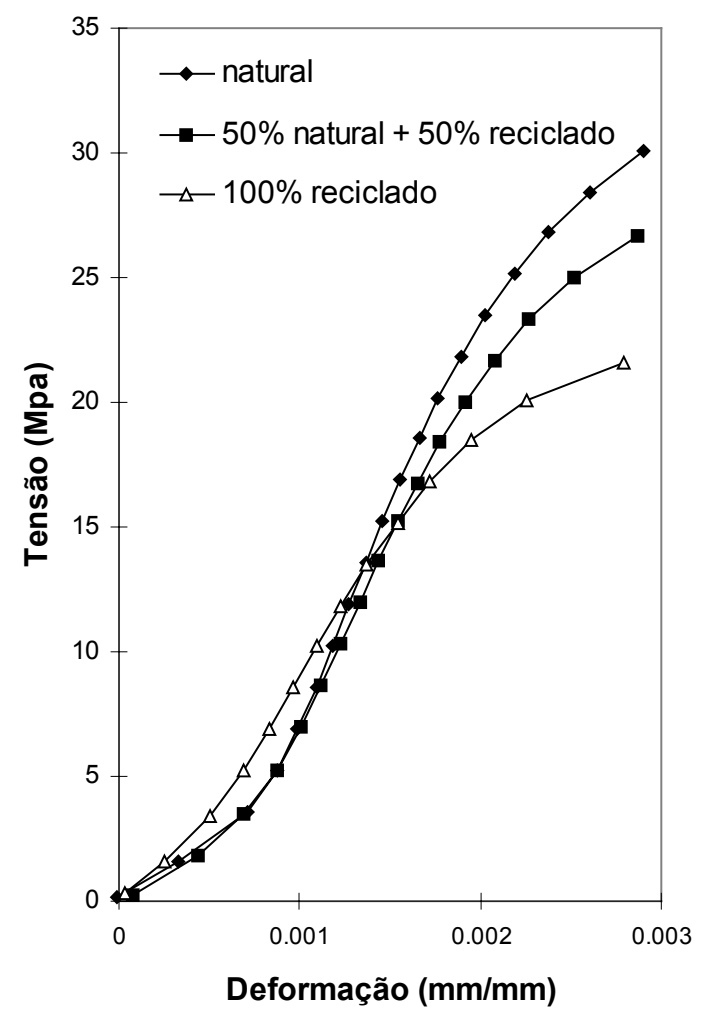

b)

Figura 7.2 - Gráficos Tensão x Deformação: (a) aos 7 dias (b)aos 28 dias

Os gráficos apresentam-se semelhantes para ambos os casos. Aos 7 dias, as curvas demonstram-se coincidentes até aproximadamente $12 \mathrm{MPa}$ onde a curva, para concreto com $100 \%$ de agregado reciclado, começa a desviar-se das demais. Para os concretos contendo $50 \%$ de reciclados e materiais naturais, as curvas Tensão $\times$ Deformação, começam a se afastar próximo ao valor de $17 \mathrm{MPa}$.

Nos ensaios realizados aos 28 dias, apesar da curva para concreto com $100 \%$ de agregado reciclado possuir, inicialmente, maior valor de tensão, para uma mesma deformação, a inclinação da curva apresentou-se maior em relação às outras duas, conferindo menor valor para o módulo de elasticidade, como pode ser verificado na Tabela 7.2. 


\subsection{Sugestões e Recomendações}

Baseados nos resultados experimentais deste estudo, o entulho reciclado usado como agregado graúdo para concreto pôde prover resistências próximas àquelas do concreto com agregado natural. Entretanto, a fim de melhor compreender seu desempenho, é recomendado que ensaios de durabilidade e características de fluência dos concretos contendo agregados reciclados sejam desenvolvidos.

Torna-se viável também que estudos nas diversas possibilidades de armadura neste tipo de painel, ainda sejam investigados.

Em áreas restritas onde as britas não estão facilmente disponíveis, este material, com os limites dos resultados obtidos no presente estudo, poderia ser usado em concretos para fabricação de pré-moldados de baixo custo, destinados por exemplo, a habitações de interesse social, dentre inúmeras outras aplicações. 


\section{CONCLUSÕES}

\subsection{Considerações Finais}

Este estudo foi conduzido para investigar o potencial do entulho reciclado como agregado graúdo na confecção de concreto. Ensaios para determinação das características físicas foram desenvolvidos nos agregados reciclado e natural e os resultados foram comparados. Para determinação da resistência à compressão simples e compressão diametral foram conduzidos ensaios em corpos-de-prova cilíndricos, e, para determinação da resistência à flexão foram realizados ensaios em painéis, utilizando-se concretos com $50 \%$ de agregados graúdos reciclados em substituição ao agregado natural e em concretos com $100 \%$ de entulho reciclado como agregado graúdo. Os resultados foram comparados com aqueles concretos contendo agregados naturais.

Os resultados mostram, sem sombra de dúvidas, a viabilidade técnica e econômica de se empregar reciclados, de construção e demolição, como agregados graúdos para concretos de baixa e média resistências.

Os resultados deste estudo incluem melhor compreensão do comportamento do "novo" concreto confeccionado com agregados de entulho reciclado pelo processo de britagem. Este conhecimento reduz significativamente o risco associado ao uso de tal concreto na prática, e irá encorajar mais profissionais da área a utilizarem esse material em obras de concreto de média e baixa resistências com as devidas restrições que lhes cabem. 


\subsection{Conclusões}

Baseado nos resultados das investigações conduzidas, as seguintes conclusões podem ser obtidas:

A utilização dos agregados graúdos provenientes da reciclagem do entulho de construção e demolição apresenta-se totalmente viável no tocante ao preparo de concretos classe C-15, com agregados nas graduações "brita 0" e brita 1" da NBR-7211/83.

A semelhança dos resultados apresentados neste estudo de caso, de natureza de composição e granulometria, comparado com outros autores, demonstra uma certa tendência nas características dos entulhos, mesmo que tomados em épocas e condições distintas.

Dadas as suas características físicas apresentadas, o agregado graúdo reciclado pode ser considerado, com certa aproximação, como sendo um agregado leve.

A absorção e índice de vazios influem significativamente na trabalhabilidade do concreto preparado com agregado reciclado. Esta influência se dá pelo aumento da velocidade de perda do abatimento, constatada nos estudos e que, pelos resultados apresentados, pode-se considerar que um concreto permaneça com boa trabalhabilidade durante, apenas $60 \mathrm{~min}$. Por outro lado, este fenômeno diminui a água livre da mistura, conferindo com isto um aumento na resistência à compressão, contribuindo ainda para uma "cura interna" do concreto.

A "procedência" do agregado (natural ou reciclado) não influencia a resistência à tração, conferindo ao concreto reciclado um comportamento que obedece as mesmas relações nas propriedades mecânicas entre resistência à tração por compressão diametral, à tração na flexão e resistência à compressão simples, que os concretos convencionais de mesma classe.

A massa específica do concreto é influenciada pela massa específica menor do agregado reciclado, fazendo com que o concreto situe-se no limite entre concretos leves e convencionais.

Não houve diferenças significativas entre o módulo de elasticidade do concreto com agregados reciclados e naturais, entretanto o concreto com reciclados pode apresentar valores de deformações bem mais elevados. 
A dureza superficial, que possui uma relação direta com a resistência à abrasão dos concretos, apresentou-se, neste caso, semelhante à dos concretos convencionais, de mesma classe de resistência.

A teoria de concreto armado convencional usada para painéis com agregado graúdo graduação brita 0 , prediz a capacidade do momento último com limites razoáveis.

O material entulho reciclado possui um grande potencial de utilização, porém estudos mais profundados devem ser conduzidos. A continuidade das pesquisas certamente fornecerá o respaldo final para utilização em larga escala deste material alternativo de construção.

Finalmente podemos concluir que ao se investir numa conscientização para reutilização dos resíduos de uma forma geral, e mais especificamente para utilização de agregados graúdos reciclados em concretos estruturais de baixa resistência, estar-se-á contribuindo com a qualidade ambiental, considerandose a não deposição clandestina do entulho na malha urbana e ainda podendo significar a redução de custos nas obras destinadas às classes sociais de baixa renda. 


\section{REFERÊNCIAS BIBLIOGRÁFICAS}

AMERICAN SOCIETY FOR TESTING AND MATERIALS (1994). $\boldsymbol{C} 7 \boldsymbol{7}$ Standard test method for flexural strength of concrete (using simple beam with third-point loading). Philadelphia.

ASSOCIAÇÃO BRASILEIRA DE NORMAS TÉCNICAS (1984). NBR 5738- Moldagem e cura de corpos de prova de concreto, cilíndricos ou prismáticos. Rio de Janeiro.

ASSOCIAÇÃO BRASILEIRA DE NORMAS TÉCNICAS (1980). NBR 5739- Ensaios de compressão de corpos de prova cilíndricos de concreto. Rio de Janeiro.

ASSOCIAÇÃO BRASILEIRA DE NORMAS TÉCNICAS (1978). NBR 6118- Projeto e execução de obras de concreto armado. Rio de Janeiro.

ASSOCIAÇÃO BRASILEIRA DE NORMAS TÉCNICAS (1983). NBR 7211-Agregado para concreto. Rio de Janeiro.

ASSOCIAÇÃO BRASILEIRA DE NORMAS TÉCNICAS (1982). NBR 7216-Amostragem de agregados. Rio de Janeiro.

ASSOCIAÇÃO BRASILEIRA DE NORMAS TÉCNICAS (1987). NBR 7217- Agregado - Determinação da composição granulométrica. Rio de Janeiro.

ASSOCIAÇÃO BRASILEIRA DE NORMAS TÉCNICAS (1982). NBR 7222- Argamassas e concretos - Determinação da resistência à tração por compressão diametral de corpos-de-prova cilíndricos. Rio de Janeiro. 
ASSOCIAÇÃO BRASILEIRA DE NORMAS TÉCNICAS (1982). NBR 7223- Concreto - Determinação da consistência pelo abatimento de tronco de cone. Rio de Janeiro.

ASSOCIAÇÃO BRASILEIRA DE NORMAS TÉCNICAS (1982). NBR 7251- Agregado em estado solto - Determinação da massa unitária. Rio de Janeiro.

ASSOCIAÇÃO BRASILEIRA DE NORMAS TÉCNICAS (1983). NBR 7810- Agregado em estado compactado seco - Determinação da massa unitária. Rio de Janeiro.

ASSOCIAÇÃO BRASILEIRA DE NORMAS TÉCNICAS (1985). NBR 8451- Postes de concreto armado para redes de distribuição de energia elétrica - Especificação. Rio de Janeiro.

ASSOCIAÇÃO BRASILEIRA DE NORMAS TÉCNICAS (1987). NBR 9776- Agregados - Determinação da massa específica de agregados miúdos por meio do frasco Chapman. Rio de Janeiro.

ASSOCIAÇÃO BRASILEIRA DE NORMAS TÉCNICAS (1987). NBR 9778- Argamassa e concreto endurecidos - Determinação da absorção de água por imersão - Índices de vazios e massa específica. Rio de Janeiro.

ASSOCIAÇÃO BRASILEIRA DE NORMAS TÉCNICAS (1987). NBR 9794- Tubo de concreto armado de seção circular para águas pluviais. Rio de Janeiro.

ASSOCIAÇÃO BRASILEIRA DE NORMAS TÉCNICAS (1987). NBR 9937- Agregados - Determinação da absorção e da massa especifica de agregado graúdo. Rio de Janeiro.

ASSOCIAÇÃO BRASILEIRA DE NORMAS TÉCNICAS (1987). NBR 9941- Redução de amostra de campo de agregados para ensaios de laboratório. Rio de Janeiro.

ASSOCIAÇÃO BRASILEIRA DE NORMAS TÉCNICAS (1987). NBR 10.004 - Resíduos sólidos - Classificação. Rio de Janeiro.

ASSOCIAÇÃO BRASILEIRA DE NORMAS TÉCNICAS (1987). NBR 10.007 - Amostragem de resíduos. Rio de Janeiro. 
ASSOCIAÇÃO BRASILEIRA DE NORMAS TÉCNICAS (1988). NBR 10.342 - Concreto fresco - Perda de abatimento. Rio de Janeiro.

ASSOCIAÇÃO BRASILEIRA DOS PRODUTORES DE CAL - ABPC (1994). Perdas de materiais nas construções. Jornal da Cal, n. 59, p.6, abr.

AGOPYAN, V (1993). O desperdício em função dos materiais e componentes. Revista Planejamento e Construção, n. 54, p. 45-47, dez.

BARRA, M. (1996). Estudio de la durabilidad del hormigón de árido reciclado en su aplicación como hormigón armado. Barcelona. Tesis (Doctoral) - Universitat Politecnica de Catalunya, Escola Tecnica Superior d'Inginieros de Caminos, Canales y Puertos.

BERNIER, G.; MALIER, Y.; MAZARS, J. (1978). Un matériau nouveau provenant de la demolition du béton: "le bibeton". C.R. Cont. Int. Sous produits et déchets dans le génie civil, Paris, p. 157-162.

BODI, J.; BRITO FILHO, J.A..; ALMEIDA, S. (1995). Utilização de entulho de construção civil reciclado na pavimentação urbana. In: REUNIÃO ANUAL DE PAVIMENTAÇÃO, 29., Cuiabá, 23-27 out. 1995. Anais. Rio de Janeiro, ABPV. p.409-436

BORTS, S. A. (1978). Waste utilization in construction. C.R. Cont. Int. Sous produits et déchets dans le génie civil, Paris, p. 9-15.

CALAVERA, J. (1991). Human and psychological aspects of the implementation of quality control in construction. In: EUROPEAN SYMPOSIUM ON MANAGEMENT, QUALITY AND ECONOMICS IN HOUSING AND OTHER BUILDING SECTORS, Lisboa, Portugal, 30 set.-4 out. 1991. Transactions. London, Spon. p. 484-494.

CSTB MAGAZINE (1993). Paris, n.68, octobre.

DERMURP. (1997). Diagnóstico da central de reciclagem de resíduo de construção civil de Ribeirão Preto. Ribeirão Preto, SP.

EMERY, J.J. (1993). Asphalt concrete recycling in Canada. Transportation Research Record, n. 1427, p. 38-46. 
GHAVAMI, K.; FANG, H.Y., eds. (1984). Low-cost and energy saving construction materials. In: INTERNATIONAL CONFERENCE ON DEVELOPMENT OF LOW-COST AND ENERGY SAVING CONSTRUCTION MATERIALS AND APPLICATIONS, Rio de Janeiro, July, v.1.

GIONGO, J.S. (1991). Argamassa armada: exemplo de cálculo de uma viga calha. São Paulo, ABCP.

HANSEN, T.C.; BOEGH, E. (1985). Elasticity and drying shrinkage of recycled-aggregate concrete. ACI Journal, v. 82, n. 56, p. 648-652, SepOct.

HANSEN, T.C. (1990). Recycled concrete aggregate and fly ash produce concrete without portland cement. Cement and Concrete Research, v. 20, p. 355-356.

HANSEN, T.C. (1992). Recycling of demolished concrete and masonry. London, E \& FN Spon.

HOSSAIN, M.; METCALF, D.G.; SCOFIELD, L.A. (1993). Performance of recycled asphalt concrete overlays in southwestern Arizona. Transportation Research Record, n. 1427, p. 30-37.

KHALOO, A. R. (1995), Crushed tile coarse agregate concrete. Cement, Concrete and Agregates. CCAGDP, v. 17, n. 2, p. 119-125, Dec.

LEVY, S. M. (1997). Reciclagem do entulho de construção civil, para utilização como agregado de argamassas e concretos. São Paulo. Dissertação (Mestrado) - Escola Politécnica, Universidade de São Paulo.

MENDONÇA, R. [1996?]. O Brasil e os resíduos sólidos - A situação atual da disposição de lixo no país: problemas, desafios, perspectivas. (cooperação técnica da JICA)

NOLASCO, A. M. (1993). Utilização de resíduos da indústria de papel na produção de materiais para a construção civil. São Carlos. Dissertação (Mestrado) - Escola de Engenharia de São Carlos, Universidade de São Paulo.

NEVILLE, A.M. (1997). Propriedades do concreto. 2.ed. São Paulo, Pini.

OFFERMAN, E.H. O futuro da reciclagem de entulho de construção. Essen, Alemanha, Universitat Gesanthochschule. p. 1-12. 
O LUCRO que vem do lixo (1996). Construção, São Paulo, n. 2505, p. 4-7, fev.

PICCHI, F. (1995). Desperdício na construção. Jornal da Cal, n. 62, p.5-7, dez.

PINTO, T. P. (1986). Utilização de resíduos de construção: estudo do uso em argamassas. São Carlos. Dissertação (Mestrado) - Escola de Engenharia de São Carlos, Universidade de São Paulo.

PINTO, T. P. (1987). Utilização de resíduos de construção: possibilidades de uso em argamassas. In: SIMPÓSIO INTERNACIONAL SOBRE PRODUÇÃO E TRANSFERÊNCIA DE TECNOLOGIA EM HABITAÇÃO: DA PESQUISA À PRÁTICA, HABITEC, São Paulo, Anais. p. 189-193, abr.

PINTO, T. P. (1992). Entulho de construção: problema urbano que pode gerar soluções. Construção, São Paulo, n. 2325, p. 11-12, ago.

PINTO, T. P. (1995). De volta à questão do desperdício. Construção, São Paulo, n. 2491, p. 18-19, nov.

PINTO, T.P. (1997). Resultados da gestão diferenciada. Téchne, São Paulo, n. 31, p. 31-34, nov-dez.

RAPHAEL, J.M. (1984). Tensile strength of concrete. ACI Journal, v. 81, n.2, p. 159-165, Mar/Apr.

RASHWAN, M. S. et al. (1995). Concrete reclamation system. Edmonton, University of Alberta, Construction Engineering and Management. (Internal report n.007)

RASHWAN, M. S.; ABOURIZK, S. (1997). The properties of recycled concrete. Concrete International, v. 19, n.7, p. 56-60, July.

RAVINDRARAJAH, R. S.; TAM, C. T. (1985). Properties of concrete made with crushed concrete as coarse aggregate. Magazine of Concrete Research, v. 37, n. 130, p. 29-38, March.

RILEM TC 121-DRG (1994). Specifications for concrete with recycled aggregates. Materials and Structures. v. 27, p. 557-559. 
ROCHA, S. (1993). Para evitar o caos. Construção, São Paulo, n. 2392, p. 69, dez.

SADEGZADEH, M.; KETTLE, R. (1986). Indirect and non-destructive methods for assessing abrasion resistance of concrete. Magazine of Concrete Research, v.38, n.137, p.183-190, Dec.

SILVEIRA, G. T. R. (1993). Metodologia de caracterização dos resíduos sólidos como base para uma gestão ambiental. Campinas. Dissertação (Mestrado) - Universidade Estadual de Campinas - UNICAMP.

SIMONS, B.; VYNCKE, J. (1993). Les déchets de construction et de démolition. C.S.T.B. Magazine, p. 32-41.

TRAVESSA, L. P.; DI MAIO,A.A.; EPERJESI, L. (1994). Use of industrial wastes in the construction industry. Housing Science, v. 18, n. 2, p. 125134.

YANNAS, F.S. (1977). Waste concrete as aggregate for new concrete. $\boldsymbol{A C I}$ Journal, v. 74, n. 37, p. 373-376, Aug.

ZORDAN, S. E. (1997), A utilização do entulho como agregado, na confecção do concreto. Campinas. Dissertação (Mestrado) - Universidade Estadual de Campinas - UNICAMP. 